GISELLE AYRES RAZERA

\title{
UM ESTUDO LONGITUDINAL DA OCORRÊNCIA DE POTENCIAIS PATÓGENOS ENTÉRICOS EM FAZENDAS COM CASOS ESPORÁDICOS E COM CASOS RECORRENTES DE DIARRÉIA EM BEZERROS DE CORTE
}




\section{GISELLE AYRES RAZERA}

\section{UM ESTUDO LONGITUDINAL DA OCORRÊNCIA DE POTENCIAIS PATÓGENOS ENTÉRICOS EM FAZENDAS COM CASOS ESPORÁDICOS E COM CASOS RECORRENTES DE DIARRÉIA EM BEZERROS DE CORTE}

Dissertação apresentada ao Programa de Pós-Graduação em Epidemiologia Experimental Aplicada às Zoonoses da Faculdade de Medicina Veterinária e Zootecnia da Universidade de São Paulo para obtenção do título de Mestre em Ciências

\section{Departamento:}

Medicina Veterinária Preventiva e Saúde Animal

Área de Concentração:

Epidemiologia Experimental Aplicada às Zoonoses

Orientador:

Prof. Dr. Paulo Eduardo Brandão

\section{São Paulo}


Autorizo a reprodução parcial ou total desta obra, para fins acadêmicos, desde que citada a fonte.

DADOS INTERNACIONAIS DE CATALOGAÇÃO-NA-PUBLICAÇÃO

(Biblioteca Virginie Buff D’Ápice da Faculdade de Medicina Veterinária e Zootecnia da Universidade de São Paulo)

Um estudo longitudinal da ocorrência de potenciais patógenos entéricos em fazendas com casos esporádicos e com casos recorrentes de diarréia em bezerros de corte / Giselle Ayres Razera. -- 2010.

135 p. : il.

Dissertação (Mestrado) - Universidade de São Paulo. Faculdade de Medicina Veterinária e Zootecnia. Departamento de Medicina Veterinária Preventiva e Saúde Animal, São Paulo, 2010.

Programa de Pós-Graduação: Epidemiologia Experimental Aplicada às Zoonoses.

Área de concentração: Epidemiologia Experimental Aplicada às Zoonoses.

Orientador: Prof. Dr. Paulo Eduardo Brandão.

1. Diarréia. 2. Bezerros de corte. 3. Vírus entéricos. 4. Parasitas. 5. Enterobactérias. I. Título. 
ERRATA

AYRES, G. R. Um estudo longitudinal da ocorrência de potenciais patógenos entéricos em fazendas com casos esporádicos e com casos recorrentes de diarréia em bezerros de corte. 2010. 135 f.

Dissertação (Mestrado em Medicina Veterinária) - Faculdade de Medicina Veterinária e Zootecnia,

Universidade de São Paulo, São Paulo, 2010.

Folha Parágrafo Onde se lê

Leia-se

Abstract 1 e recorrentes de diarréia em bezerros de corte.

e com casos recorrentes de diarréia em bezerros de corte. 
UNIVERSIDADE DE SÃo PAULO

FACULDADE DE MEDICINA VETERINÁRIA E ZOOTECNI Comissao Bioetica

\section{CERTIFICADO}

Certificamos que o Projeto intitulado "Diarréia neonatal em bovinos de corte: Estudo longitudinal da ocorrência de patógenos transmissíveis em propriedades com casos esporádicos e com casos recorrentes", protocolado sob o n 1599/2009, utilizando 60 (sessenta) bovinos, sob a responsabilidade do Prof. Dr. Paulo Eduardo Brandão, está de acordo com os princípios éticos de experimentação animal da Comissão de Bioética da Faculdade de Medicina Veterinária e Zootecnia da Universidade de São Paulo e foi aprovado em reunião de 18 de março de 2009.

We certify that the Research "Calf diarrhea in beef cattle: longitudinal study of the transmissible pathogens occurrence in farms with recurrent and sporadic cases", protocol number 1599/2009, utilizing 60 (sixty) bovines, under the responsibility Prof. Dr. Paulo Eduardo Brandão, agree with Ethical Principles in Animal Research adopted by Bioethic Commission of the School of Veterinary Medicine and Animal Science of University of São Paulo and was approved in the meeting of day $03 / 18 / 09$.

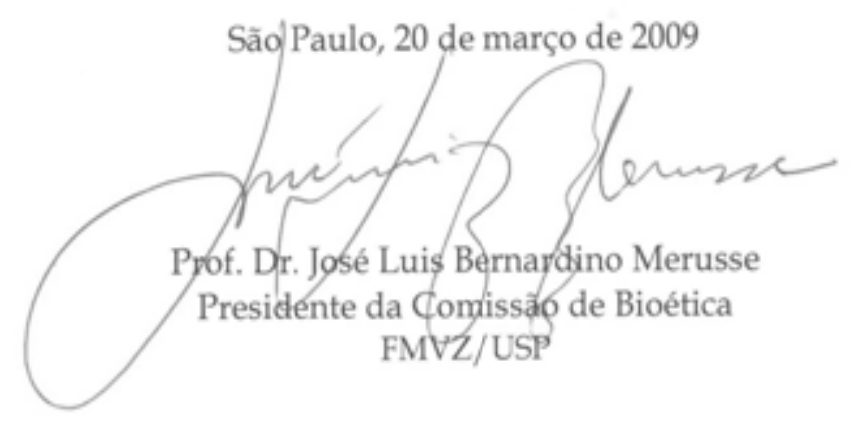


FOLHA DE AVALIAÇÃO

Nome: AYRES, Giselle Razera

Título: Um estudo longitudinal da ocorrência de potenciais patógenos entéricos em fazendas com casos esporádicos e com casos recorrentes de diarréia em bezerros de corte

Dissertação apresentada ao Programa de PósGraduação em Epidemiologia Experimental Aplicada às Zoonoses da Faculdade de Medicina Veterinária e Zootecnia da Universidade de São Paulo para obtenção do título de Mestre em Ciências

Data:

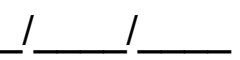

BANCA EXAMINADORA

Prof. Dr. Instituição:

Assinatura: Julgamento:

Prof. Dr. Instituição:

Assinatura: Julgamento:

Prof. Dr. Instituição:

Assinatura: Julgamento: 
Ao Guto,

Meu grande amor,

Companheiro de todas as horas,

Meu melhor amigo,

Meu escolhido para construir um lindo futuro,

Dedico essa realização. 


\section{AGRADECIMENTOS ESPECIAIS}

À Deus, por todas as oportunidades que tive em minha vida e por ter saúde para aproveitá-las.

À minha mãe, Miriam Cristina de C. M. Ayres, pela presença e amor incondicionais.

Ao meu pai, Edevaldo Razera, por toda a torcida e amor.

Aos meus irmãos, Caroline Ayres Razera e Bruno Ayres Razera, pela paciência e amor.

Ao Prof. Dr. Paulo Eduardo Brandão,

pela amizade, confiança e exemplo de generosidade no ato diário de ensinar e repensar a Ciência. 


\section{AGRADECIMENTOS}

Agradeço a todos os que tenham colaborado para a execução desse trabalho, com os quais eu possa ser injusta por não mencionar nesse momento.

Ao Prof. Dr. Ed. Hoffmann Madureira, Prof. Mario Binelli, Profa. Dra. Cláudia Bertan e Dr. Luis Augusto Ferreira Rossa, pela iniciação na carreira científica.

À Dra. Laura Villarreal, pela amizade, pelos conhecimentos compartilhados e pela indicação para cursar o mestrado sob orientação do Prof. Dr. Paulo Eduardo Brandão,

Ao Prof. Dr. Leonardo José Richtzenhain, por me inspirar a ingressar na Medicina Veterinária Preventiva.

Ao Profa. Dra. Solange Maria Gennari, Prof. Dr. Rodrigo Martins Soares, Prof. Dr. Nilson Roberto Benites por seu envolvimento no planjamento e apoio à realização desse trabalho.

A todos os professores do VPS, que contribuem com a minha contínua formação.

À Dra. Pricila Anne Melville por me iniciar e conduzir na microbiologia e pela amizade e apoio incondicionais.

À amiga Mikaela Renata Funada por me iniciar na parasitologia e à Dra Hilda Fátima de Jesus Pena pela disponibilidade em atender as minhas dúvidas na realização dos exames.

À amiga Karen Asano pela amizade e por me inciar na prática da biologia molecular.

Ao Prof. Marcos Bryan Heinemann, pela disposição em ajudar e auxílio prático na realização da genotipagem das E. coli. 
Às grandes amigas: Camila Oliveira, Carolina Torres, Iracema Nunes e Sueli Santos, por todo o companheirismo, apoio e auxílio prático para a conclusão desse trabalho, sem vocês não teria sido possível!

Às amigas Sheila Oliveira de Souza, Juliana Martins e Alessandra Castro por tudo o que me ensinaram e por auxiliarem sempre que precisei.

À companheira de todas as horas, Flavia Regina Oliveira de Barros, pela amizade verdadeira, demonstrada pela presença e apoio nos momentos difíceis, inclusive auxíliando na formatação e correção desse trabalho.

Aos amigos do VPS, que tive o privilégio de descobrir entre pós-graduandos e funcionários, felizmente muitos para serem aqui citados, por toda a ajuda, torcida e agradáveis momentos compartilhados.

A todos os funcionários do VPS, pela ajuda na realização desse trabalho.

À Tânia Delonero, por seu apoio prático na secretaria da pós-graduação e, principalmente, pela amizade.

Às funcionárias da Biblioteca Virginie Buff D' Ápice pelo carinho com o qual sempre me receberam e auxiliaram, sempre que precisei, desde a graduação.

Ao Prof. Dr. José Ricardo C. M. Ayres, meu querido tio, pelo convite à filosofia e por me fazer despertar para uma experiência científica.

À toda a minha família, os Ayres, os Razera e os Rossa, pela paciência, apoio e amor.

Ao Prof. Dr. Silvio Arruda Vasconcelos e à Profa. Dra. Solange Maria Gennari pela dedicação ao programa de pós-graduação. 
À Prefeitura do Campus de Pirassununga da Universidade de São Paulo e ao João Cravinhos, responsável pela propriedade em Descalvado-SP, por permitirem que eu realizasse o trabalho.

Aos funcionário de ambas às propriedades, pelo auxílio sem o qual esse trabalho não se realizaria e por tudo o que me ensinaram.

Aos animais utilizados nesse estudo, pela "paciência" e "compreensão".

À Fundação de Amparo à Pesquisa do Estado de São Paulo (FAPESP), pela bolsa concedida. 


\section{Incompatibilidade}

E bate louco, bate criminosamente

O coração mais do que a mente,

Bate o pé mais do que o corpo poderia

E se você mentalizasse na folia

Sabe lá se não seria a solução prá de manhã pensar melhor

E caso fosse a incompatibilidade entre o corpo e consciência

Iria desaparecer, você não vê

Como o corpo preparado pode ser iluminado

Como a luz de uma fogueira que precisa se manter

E atingido pela plena consciência

De que o corpo em decadência faz a tua consciência esmorecer

Pelos poros elimina-se o que o corpo não precisa

E não precisa pra pensar abdicar desse prazer

Se você dançar a noite inteira não significa dar bobeira

De manhã se alienar ou esquecer

É a busca do supremo equilíbrio,

Num processo inteligente sua mente clarear sem perceber

E a intelectualidade

Pode dançar sem receio

Descanso é pra alimentar

E trabalhar sem anseio

Eu tô olhando pra ponta

Mas não esqueço do meio

Quem acha o corpo uma ofensa

Falo sem demagogia

Pode dançar essa noite

E amanhã pensar quem diria

Quem não entendeu eu lamento

Quero que entenda algum dia

(Oswaldo Montenegro) 


\section{RESUMO}

AYRES, G. R. Um estudo longitudinal da ocorrência de potenciais patógenos entéricos em fazendas com casos esporádicos e com casos recorrentes de diarréia em bezerros de corte. [A longitudinal study on the occurrence of potential enteric pathogens in farms with recurrent and sporadic cases of diarrhea in beef calves]. 2010. 135 f. Dissertação (Mestrado em Medicina Veterinária) - Faculdade de Medicina Veterinária e Zootecnia, Universidade de São Paulo, São Paulo, 2010.

A diarréia em bezerros é comprovadamente uma das principais causas de perdas econômicas em rebanhos de corte, sendo os prejuízos diretamente derivados da redução do ganho de peso e custos com tratamento. Considerando-se que, para o delineamento de medidas profiláticas adequadas ao controle de uma doença é necessário o conhecimento de suas causas, o presente trabalho teve por objetivo estudar de modo longitudinal a freqüência de ocorrência de coronavírus bovino $(\mathrm{BCoV})$, rotavírus do grupo $\mathrm{A}(\mathrm{RV}-\mathrm{A})$, protozoários, helmintos e enterobactérias em uma propriedade com casos esporádicos e em outra com casos recorrentes de diarréia em bezerros. Investigou-se, ainda, a presença de genes codificadores de para as toxinas shiga-like 1 e 2 , para as adesinas K99 e F41 e para a intimina (eae) nas E. coli isoladas. Para a detecção de BCoV, utilizou-se uma nested-RT-PCR direcionada ao gene codificador da RNA polimerase RNA dependente, e para a detecção de RV-A utilizou-se ELISA direto duplo sanduíche. $O$ isolamento e caracterização bioquímica das colônias de bactérias foram conduzidos de acordo com técnicas de bacteriologia clássica. A caracterização genotípica das colônias de E. coli isoladas foi realizada através de uma Multiplex-PCR, utilizando primers para os genes codificadores dos seguintes fatores de virulência: Stx1, Stx2, Sta, K99, F41 e eae. A detecção de parasitas foi realizada por centrífugo sedimentação em águaeter e centrífugo-flutuação em solução supersaturada de sacarose, considerando-se como resultado final do exame coproparasitológico todos os parasitas encontrados em ambas as técnicas em sua maior contagem. A freqüência de ocorrência de coronavírus bovino e rotavírus do grupo $\mathrm{A}$ foi baixa, restrita a animais com até quatro meses de idade, enquanto que protozoários, helmintos e enterobactérias apresentaram tendência crescente em freqüência relacionada à progressão da idade dos animais. Foram identificados os patotipos STEC, AEEC e um padrão atípico com 
os genes de K99 e eae. Além disso, encontrou-se associação entre baixo padrão sanitário e maior freqüência de ocorrência de Eimeria spp, Strongyloidea, Strongyloides spp, Trichuris spp e Escherichia coli portadora de fatores de virulência Stx1, Stx2, K99 e eae. O presente trabalho colabora para a caracterização da microbiota entérica de bezerros, mas mantém abertas as questões relativas às diferenças específicas entre as biotas entéricas de bezerros sadios e com diarréia, enfatizando a importância de se realizarem mais estudos que investiguem simultaneamente diversos enteropatógenos potenciais nestes animais.

Palavras-chave: Diarréia. Bezerros de corte. Vírus entéricos. Parasitas. Enterobactérias. 


\section{ABSTRACT}

AYRES, G. R. A longitudinal study on the occurrence of potential enteric pathogens in farms with recurrent and sporadic cases of diarrhea in beef calves. [Um estudo longitudinal da ocorrência de potenciais patógenos entéricos em fazendas com casos esporádicos e recorrentes de diarréia em bezerros de corte]. 2010. 135 f. Dissertação (Mestrado em Medicina Veterinária) - Faculdade de Medicina Veterinária e Zootecnia, Universidade de São Paulo, São Paulo, 2010.

Diarrhea in calves is proved to be one of the main causes of economic loss in beef herds, which is direct originated by reduction of weight gain and increment of treatment costs. It is known that the determination of appropriate preventive measures to control a disease depends on the knowledge of its causes. In this manner, the present work aimed to study longitudinally the frequency of occurrence of bovine coronavirus (BCoV), group A rotavirus (RV-A), protozoa, helminths and enterobacteria in a beef farm presenting sporadic cases and other with recurrent cases of diarrhea. Moreover, the presence of genes that express the following virulence factors were investigated in the isolated $E$. coli: shiga-like toxins 1 and 2 , adhesins K99 and F41 and intimin (eae). A nested-RT-PCR targeted to the RNAdependent RNA polimerase gene was conducted to detect $\mathrm{BCoV}$, and a doublesandwich direct ELISA was used to detect RV-A. Classical bacteriology techniques were used to isolate and indentify bacterial colonies. A Multiplex-PCR, with primers designed to previously described E. coli genes, was used to genotype these colonies. Centrifuge sedimentation in water-ether and centrifuge flotation in sucrose supersaturated solution were used to detect the presence of parasites. The final result was achieved by the highest count of all the parasites found. The observed frequency of occurrence of both BCoV and RV-A was low and restricted to animals up to 4 months of age whereas protozoa, helminths and enterobacteria showed an increasing tendency on its frequency related to progression of animals aging. STEC, AEEC and an atypical pathotype of E. coli, with K99 and eae genes were found. Moreover, an association between low sanitary pattern and a higher frequency of Eimeria spp, Strongyloidea, Strongyloides spp, Trichuris spp and Escherichia coli bearing Stx1, Stx2, K99 and eae genes was observed. The present study contributes to the characterization of calf enteric microbiota. However, the points related to the 
specific differences between healthy and diarrheic calves enteric microbiota remain unclear, emphasizing the importance of future studies to investigate different potential enteropathogens in beef calves simultaneously.

Key words: Diarrhea. Beef calves. Enteric viruses. Parasites. Enterobacteria. 


\section{LISTA DE FIGURAS}

Figura 1 - Apresentação esquemática da coleta de amostras na fazenda do campus da USP de Pirassununga.

Figura 2 - Coleta de amostra fecal da ampola retal de bezerros com cerca de uma semana de vida: conteúdo fecal (à esquerda) e swab (à direita)

Figura 3 - - Amostras coletadas mantidas em recipiente isolante e mantidas sob refrigeração

Figura 4 - Fluxograma dos procedimentos realizados para obtenção de amostras e respectivas alíquotas

Figura 5 - - Fluxograma dos procedimentos realizados para diagnóstico bacteriológico

Figura 6 - Fluxograma dos procedimentos realizados para diagnóstico parasitológico: método de Sheather modificado (à esquerda) e método de Ritchie modificado (à direita) .

Figura 7 - $\quad$ - Fluxograma dos procedimentos realizados para a investigação da presença de RV-A do grupo A utilizando ELISA direto duplosanduíche.

Figura 8 - Freqüência de ocorrência de diarréia, coronavírus bovino $(\mathrm{BCoV})$, rotavírus do grupo $\mathrm{V}(\mathrm{R} \vee-\mathrm{A})$, amostras negativas ao exame coproparasitológico, protozoários, helmintos e E. coli portadora de genes codificadores para fatores de virulência nas 4 colheitas realizadas $(1,2,3$ e 4$)$ nos dois lotes de animais ( $\mathrm{L} 1 \mathrm{e}$ L2), na propriedade com casos esporádicos de diarréia.

Figura 9 - Freqüência de ocorrência de genes codificadores de toxina Shiga-like 1(Stx1), intimina (eae) e adesina K99 em colônias de E. coli isoladas de amostras fecais de bezerros da propriedade com casos esporádicos de diarréia.

Figura 10 - - Freqüência de ocorrência de genes codificadores de toxina Shiga-like 1 (Stx1), Shiga-like 2 (Stx2) e intimina (eae) em colônias de E. coli isoladas de amostras fecais de bezerros da propriedade com casos esporádicos de diarréia 
Figura 11 - - Freqüência de ocorrência de genes codificadores de toxina Shiga-like 1 (Stx1), Shiga-like 2 (Stx2) e intimina (eae) em colônias de $E$. coli isoladas de amostras fecais de bezerros da propriedade com casos esporádicos de diarréia

Figura 12 - - Freqüência de ocorrência de casos de diarréia nas propriedades com casos esporádicos (fazenda 1) e recorrentes (fazenda 2) nos dois lotes ( $L 1$ e $L 2)$ de animais estudados, nas colheitas (C1, C2, $\mathrm{C} 3$ e C4)

Figura 13 - Freqüência de ocorrência de coronavírus bovino (BCoV) e rotavírus do grupo A (RV-A) nas propriedades com casos esporádicos (fazenda 1) e recorrentes (fazenda 2) nos dois lotes (L1 e L2) de animais estudados, nas colheitas (C1, C2, C3 e C4).. 86

Figura 14 - - Freqüência de ocorrência de amostras negativas (Neg.) e positivas para protozoários (Protoz.) e helmintos (Helm.) nas propriedades com casos esporádicos (fazenda 1) e recorrentes (fazenda 2) nos dois lotes (L1 e L2) de animais estudados, nas colheitas (C1, C2, C3 e C4)

Figura 15 - - Freqüência de ocorrência de E. coli portadora de genes codificadores de fatores de virulência nas propriedades com casos esporádicos (fazenda 1) e recorrentes (fazenda 2) nos dois lotes (L1 e L2) de animais estudados, nas colheitas (C1, C2, C3 e C4)

Figura 16 - - Freqüência de ocorrência de genes codificadores de toxina Shiga-like 1(Stx1), toxina Shiga-like2 (Stx2) intimina (eae) e adesina K99 em colônias de E. coli isoladas de amostras fecais colhidas nas propriedades com casos esporádicos (fazenda 1) e recorrentes (fazenda 2) nos dois lotes ( $L 1$ e $L 2)$ de animais estudados, nas colheitas (C1, C2, C3 e C4) 


\section{LISTA DE QUADRO}

Quadro 1 - - Critério utilizado para diluição das alíquotas fecais para exame virológico

Quadro 2 - - Genes codificadores de fatores de virulência de E. coli investigados pela mulptiplex-PCR com seus respectivos primers para amplificação no sentido 5'-3' (F - foward) e no sentido 3'-5' ( $R$ - reverse) e os respectivos tamanhos de fragmento esperados, em pares de bases $(\mathrm{pb})$

Quadro 3 - - Ciclos de temperatura com seus respectivostempos de duração para a realização de Mutiplex-PCR para detecção de genes codificadores de fatores de virulência de E. coli (OK et al., 2009) .. 45

Quadro 4 - - Critério semi-quantitativo utilizado para classificação das amostras ao exame coproparasitológico ......................................4 47

Quadro 5 - - Primers dirigidos ao gene da RdRp utilizados na nested-RTPCR para a detecção de coronavírus bovino

Quadro 6 - - Primers utilizados para detecção do gene codificador da proteína $\mathrm{S}$ dos $\mathrm{BCoV}$, com os respectivos tamanhos de fragmentos amplificados

Quadro 7 - - Data de realização das colheitas na fazenda com casos esporádicos de diarréia dos lotes 1 (L1) e 2 (L2) .......................... 56

Quadro 8 - - Datas de realização das colheitas na fazenda com casos recorrentes de diarréia dos lotes 1 (L1) e 2 (L2) 


\section{LISTA DE TABELAS}

Tabela 1 - Espécies de bactérias isoladas de swabs retais de bezerros de corte na primeira colheita realizada na fazenda com casos esporádicos de diarréia. São Paulo, 2008. 58

Tabela 2 - Parasitas identificados por exame coproparasitológico em amostras fecais de bezerros de corte na segunda colheita realizada na fazenda com casos esporádicos de diarréia. São Paulo, 2008-2009.

Tabela 3 - Parasitas identificados por exame coproparasitológico em amostras fecais de bezerros de corte na segunda colheita realizada na fazenda com casos esporádicos de diarréia, pela técnica de centrífugo-flutuação em solução supersaturada de sacarose (método de Sheater modificado) e de centrífugosedimentação em água-éter (método de Ritchie). São Paulo, 2008-2009.

Tabela 4 - Espécies de bactérias isoladas de swabs retais de bezerros de corte na segunda colheita realizada na fazenda com casos esporádicos de diarréia. São Paulo, 2008-2009.

Tabela 5 - Parasitas identificados por exame coproparasitológico em amostras fecais de bezerros de corte na terceira colheita realizada na fazenda com casos esporádicos de diarréia. São Paulo, 20082009.

Tabela 6 - Parasitas identificados por exame coproparasitológico em amostras fecais de bezerros de corte na terceira colheita realizada na fazenda com casos esporádicos de diarréia, pela técnica de centrífugo-flutuação em solução supersaturada de sacarose (método de Sheater modificado) e de centrífugo-sedimentação em água-éter (método de Ritchie). São Paulo, 2008-2009.

Tabela 7 - Espécies de bactérias isoladas de swabs retais de bezerros de corte na terceira colheita realizada na fazenda com casos esporádicos de diarréia. São Paulo, 2008-2009. 
Tabela 8 - Espécies de bactérias isoladas de swabs retais de bezerros de corte na terceira colheita realizada na fazenda com casos esporádicos de diarréia. São Paulo, 2008-2009.

Tabela 9 - Parasitas identificados por exame coproparasitológico em amostras fecais de bezerros de corte na quarta colheita realizada na fazenda com casos esporádicos de diarréia. São Paulo, 2009. . 66

Tabela 10 - Espécies de bactérias isoladas de swabs retais de bezerros de corte na quarta colheita realizada na fazenda com casos esporádicos de diarréia. São Paulo, 2009.

Tabela 11 - Parasitas identificados por exame coproparasitológico em amostras fecais de bezerros de corte na primeira colheita realizada na fazenda com casos recorrentes de diarréia. São Paulo, 2009.

Tabela 12 - Parasitas identificados por exame coproparasitológico em amostras fecais de bezerros de corte na primeira colheita realizada na fazenda com casos recorrentes de diarréia, pela técnica de centrífugo-flutuação em solução supersaturada de sacarose (método de Sheater modificado) e de centrífugosedimentação em água-éter (método de Ritchie). São Paulo, 2009.

Tabela 13 - Espécies de bactérias isoladas de swabs retais de bezerros de corte na primeira colheita realizada na fazenda com casos recorrentes de diarréia. São Paulo, 2009.

Tabela 14 - Parasitas identificados por exame coproparasitológico em amostras fecais de bezerros de corte na segunda colheita realizada na fazenda com casos recorrentes de diarréia. São Paulo, 2009.

Tabela 15 - Parasitas identificados por exame coproparasitológico em amostras fecais de bezerros de corte na segunda colheita realizada na fazenda com casos recorrentes de diarréia, pela técnica de centrífugo-flutuação em solução supersaturada de sacarose (método de Sheater modificado) e de centrífugosedimentação em água-éter (método de Ritchie). São Paulo, 2009. 
Tabela 16 - Espécies de bactérias isoladas de swabs retais de bezerros de corte na segunda colheita realizada na fazenda com casos recorrentes de diarréia. São Paulo, 2009.

Tabela 17 - Parasitas identificados por exame coproparasitológico em amostras fecais de bezerros de corte na terceira colheita realizada na fazenda com casos recorrentes de diarréia. São Paulo, 2009. .. 75

Tabela 18 - Parasitas identificados por exame coproparasitológico em amostras fecais de bezerros de corte na terceira colheita realizada na fazenda com casos recorrentes de diarréia, pela técnica de centrífugo-flutuação em solução supersaturada de sacarose (método de Sheater modificado) e de centrífugo-sedimentação em. água-éter (método de Ritchie). São Paulo, 2010.

Tabela 19 - Espécies de bactérias isoladas de swabs retais de bezerros de corte na terceira colheita realizada na fazenda com casos recorrentes de diarréia. São Paulo, 2010.

Tabela 20 - Parasitas identificados por exame coproparasitológico em amostras fecais de bezerros de corte na quarta colheita realizada na fazenda com casos recorrentes de diarréia. São Paulo, 2010. ..79

Tabela 21 - Parasitas identificados por exame coproparasitológico em amostras fecais de bezerros de corte na segunda colheita realizada na fazenda com casos esporádicos de diarréia. São Paulo, 2008-2009.

Tabela 22 - Espécies de bactérias isoladas de swabs retais de bezerros de corte na quarta colheita realizada na fazenda com casos recorrentes de diarréia. São Paulo, 2010 


\section{LISTA DE ABREVIATURAS E SIGLAS}

$\begin{array}{ll}\text { ABTS } & \text { 2,2'-Azino-bis(3-etilbenzo-tiazolina-6-acido sulfônico)diamonio } \\ \text { Ac } & \text { anticorpo(s) } \\ \text { BCoV } & \text { Coronavírus bovino } \\ \text { cDNA } & \text { Ácido desoxirribonucléico complementar } \\ \text { DEPC } & \text { Dietil-pirocarbonato } \\ \text { DNA } & \text { Ácido desoxirribonucléico } \\ \text { dNTP } & \text { Deoxinucleosídeo-trifosfato } \\ \text { DO } & \text { Densidade óptica } \\ \text { ELISA } & \text { Enzyme-linked immunosorbent assay } \\ \text { et al. } & \text { e colaboradores } \\ \text { g } & \text { Grama(s) } \\ \text { h } & \text { Hora (s) } \\ \text { Kb } & \text { Quilobase (s) } \\ \text { kD } & \text { QuiloDalton (s) } \\ \text { L } & \text { Litro(s) } \\ \text { m } & \text { Metro (s) } \\ \text { M } & \text { Molar } \\ \text { min } & \text { Minuto de hora } \\ \text { NA } & \text { Não se aplica } \\ \text { ORF } & \text { Open reading frame } \\ \text { pb } & \text { Par (es) de base (s) } \\ \text { PCR } & \text { Reação pela polimerase em cadeia } \\ \text { PBS } & \text { Fosfato salino tamponado } \\ \text { PCR } & \text { Reação pela polimerase em cadeia } \\ \text { pH } & \text { Concentração de hidrogênio iônico } \\ \text { RNA } & \text { Rotavonucléico } \\ \text { RT } & \text { Segundo (s) } \\ \text { RV-A } & \text { Sodecil sulfato de sódio } \\ \text { SDS } & \end{array}$


spp

subesp.

TBE

TM

TRIS

UA

x $\mathrm{g}$

\section{Espécies}

Subespécie

TRIS Borato EDTA

Trademark

Tris(hidroximetil)aminometano

Unidade (s) de absorbância

Aceleração da gravidade $\left(9,8 \mathrm{~m} / \mathrm{s}^{2}\right)$ 


\section{LISTA DE SÍMBOLOS}

$\begin{array}{ll}{ }^{\circ} \mathrm{C} & \text { Graus Celsius } \\ + & \text { Mais } \\ \circledR & \text { Marca Registrada } \\ \mu & \text { Micro } \\ \mathrm{m} & \text { Mili } \\ \mathrm{n} & \text { Nano } \\ \mathrm{p} & \text { Pico } \\ \% & \text { Porcentagem / Porcento }\end{array}$




\section{SUMÁRIO}

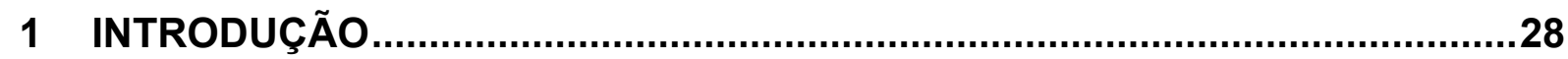

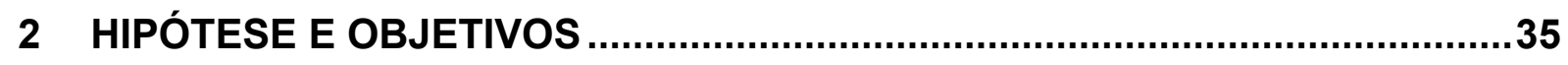

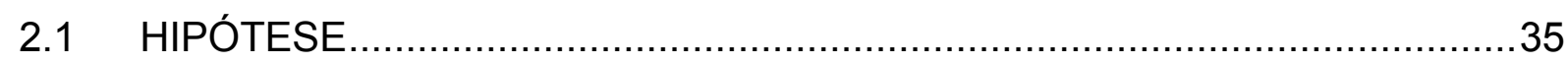

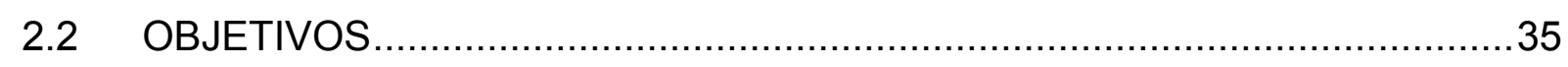

3 MATERIAIS E MÉTODOS.......................................................................37

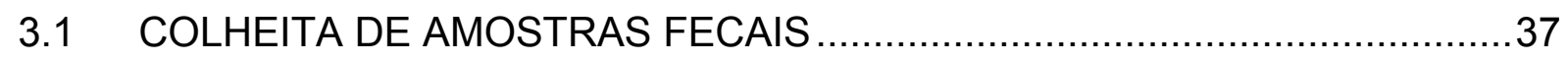

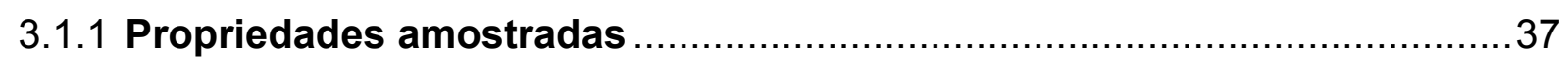

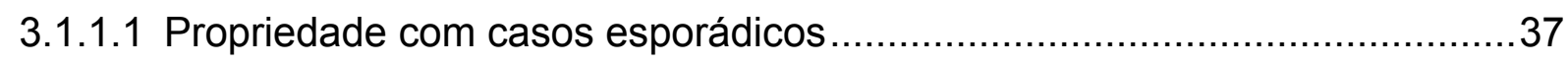

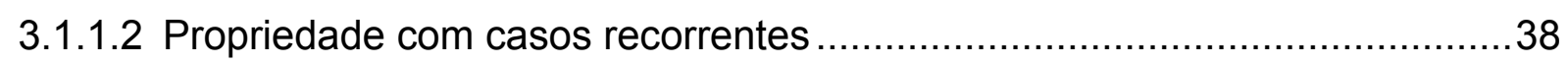

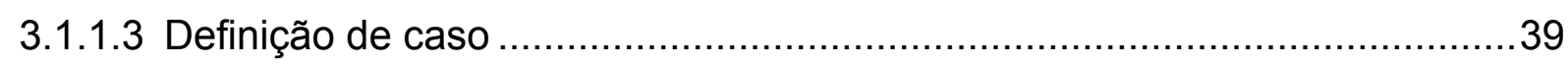

3.1.2 Procedimentos para colheita, transporte e armazenamento de amostras .........39

3.2 DETECÇÃO E IDENTIFICAÇÃO DE ENTEROBACTÉRIAS ........................42

3.3 DETECÇÃO DE FATORES DE VIRULÊNCIA DE ESCHERICHIA COLI .......43

3.4 PESQUISA DE PROTOZOÁRIOS E HELMINTOS ….................................45

3.5 PESQUISA DE CORONAVÍRUS BOVINO (BCOV) …….......................4

3.6 RT-PCR PARA A AMPLIFICAÇÃO DA REGIÃO CODIFICADORA DA SUBUNIDADE S1 DA PROTEÍNA S DE CORONAVÍRUS BOVINO ..............49

3.7 PESQUISA DE ROTAVIRUS (RV-A) DO GRUPO A …............................50

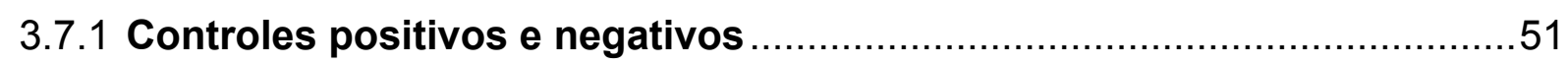

3.7.1.1 Sensibilização das placas, anticorpos primário, secundário e conjugado ....51

3.7.2 Aplicação do elisa às amostras fecais …….........................................52

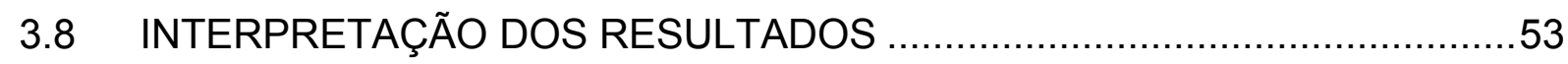

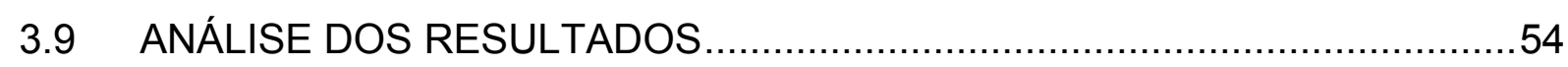

4 RESULTADOS

4.1 PROPRIEDADE COM CASOS ESPORÁDICOS DE DIARRÉIA ….................56

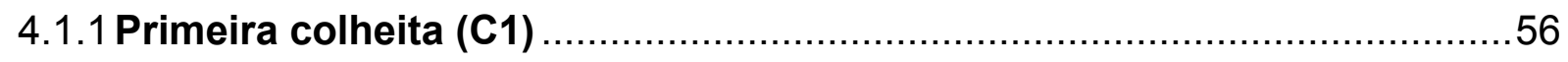

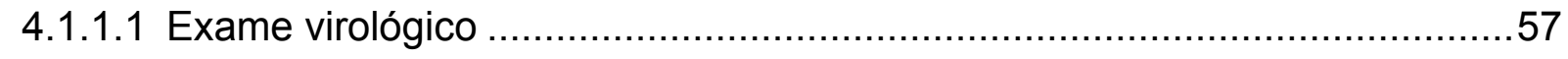




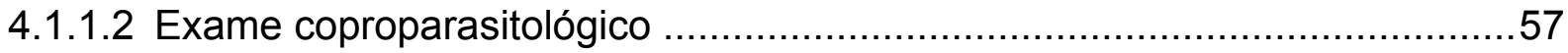

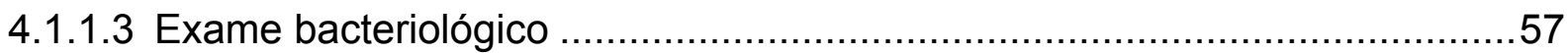

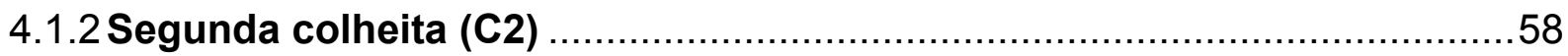

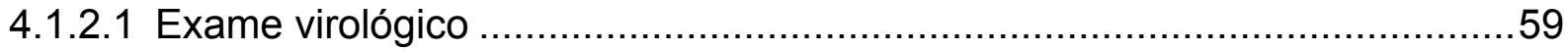

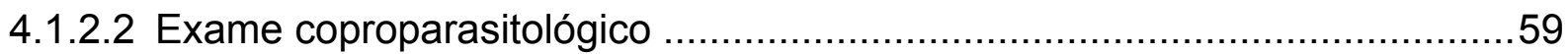

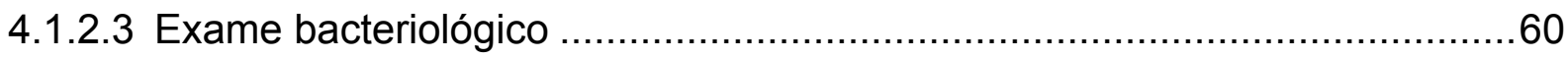

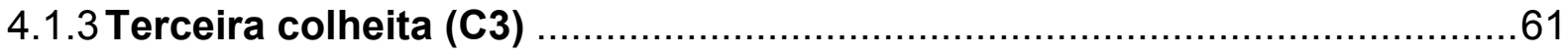

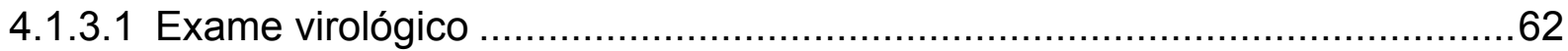

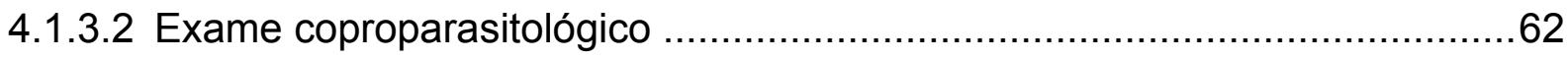

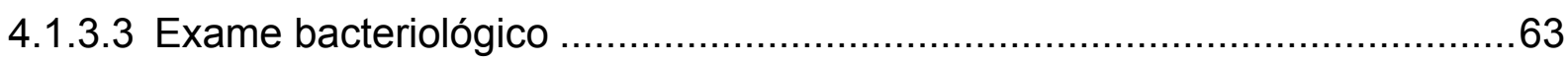

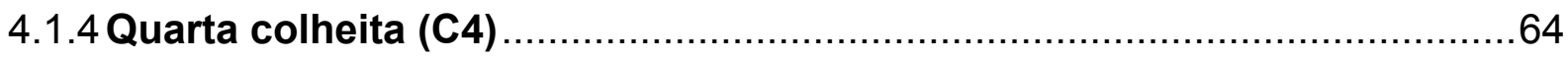

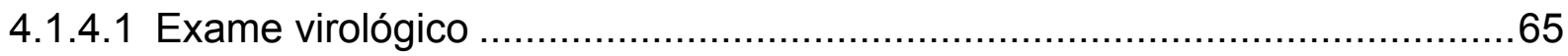

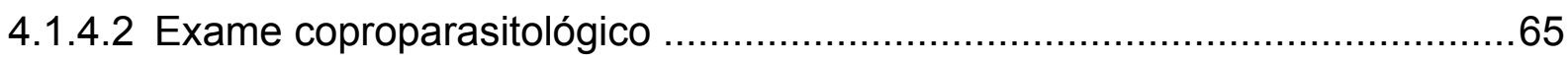

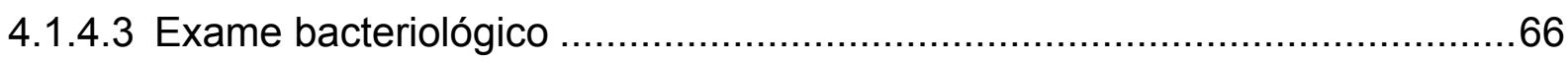

4.2 PROPRIEDADE COM CASOS RECORRENTES DE DIARRÉIA...................67

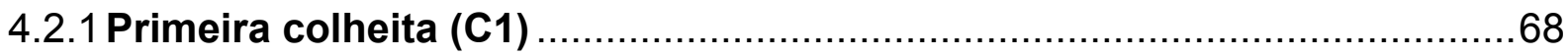

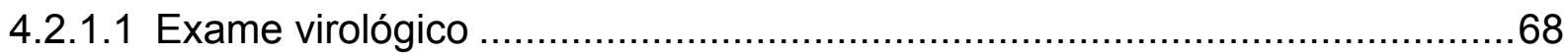

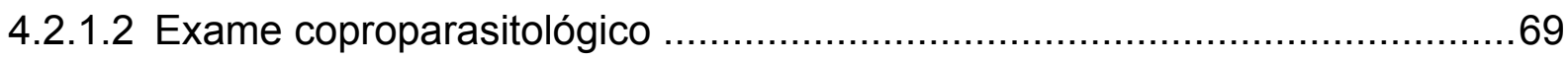

4.2.1.3 Exame bacteriológico ...................................................................

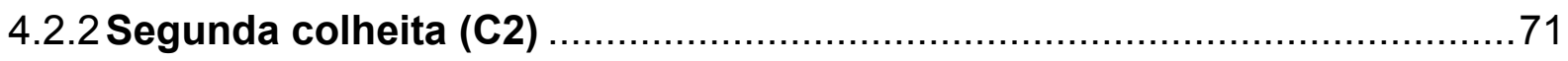

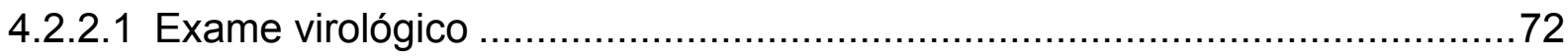

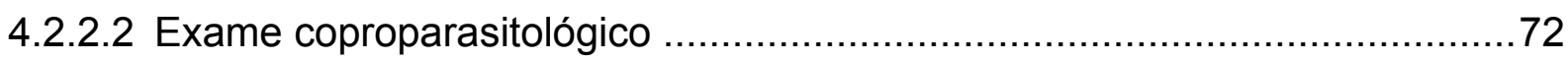

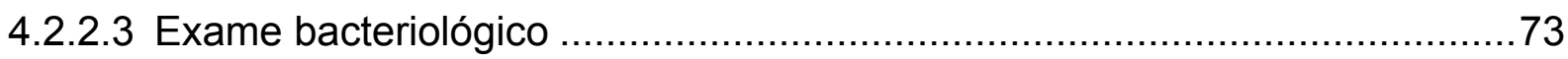

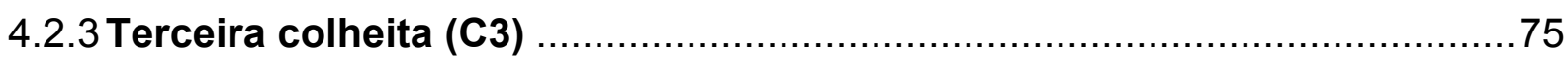

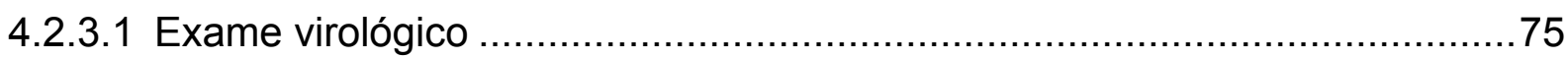

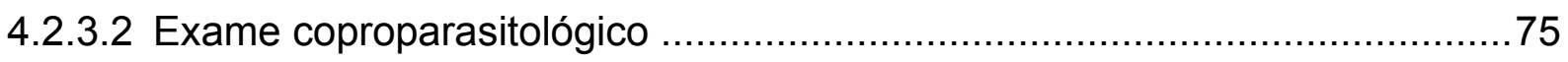

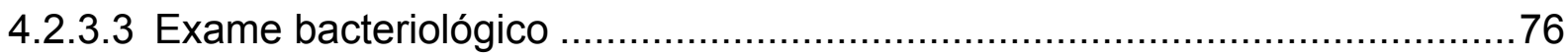

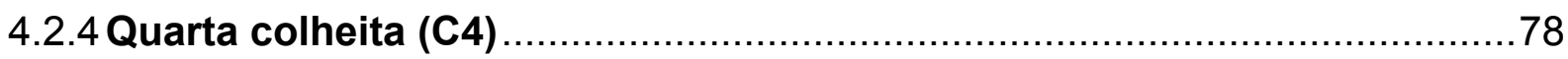

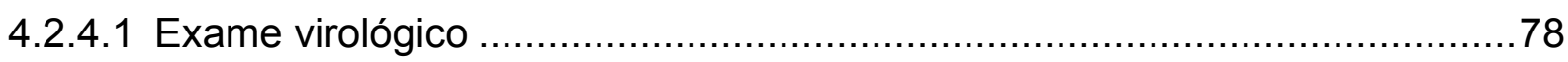

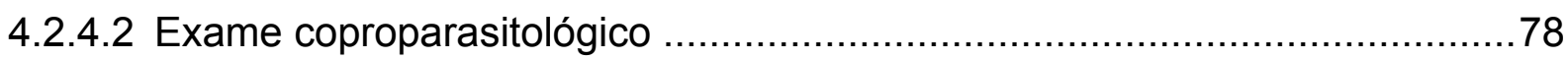




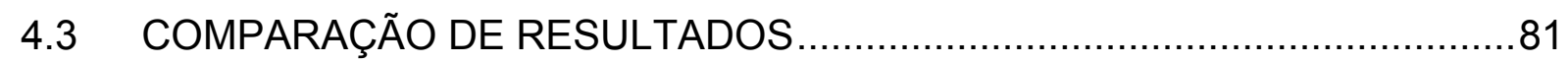

4.3.1Comparação entre colheitas realizadas na fazenda com casos esporádicos de diarréia (fazenda 1) ............................................ 81

4.3.2 Comparação entre colheitas realizadas na fazenda com casos recorrentes

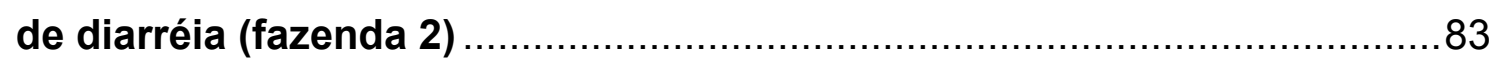

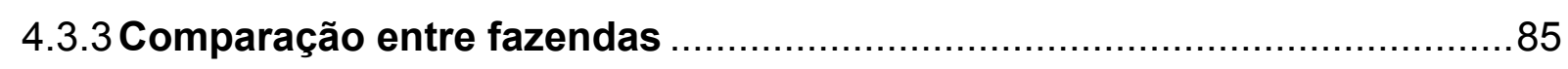

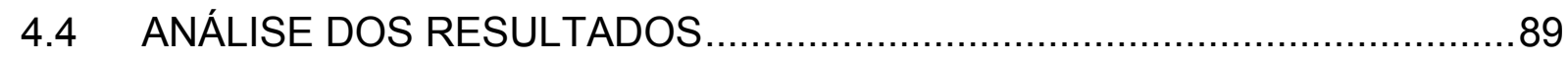

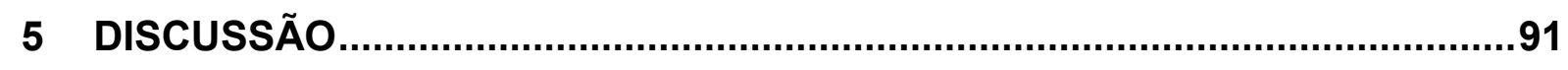

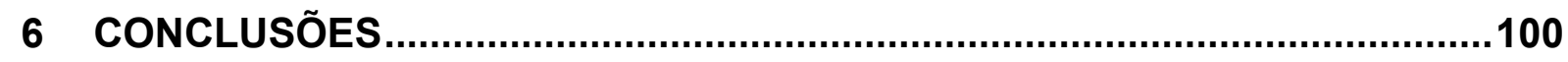

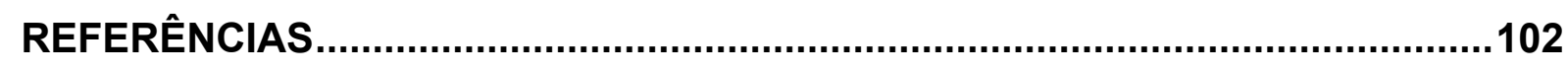

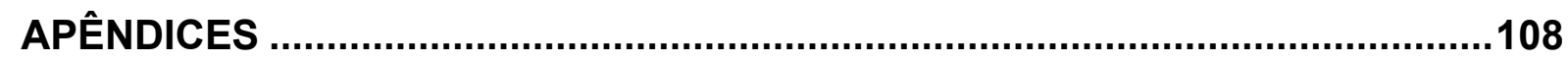


INTRODUÇÃO 


\section{INTRODUÇÃO}

A diarréia em bezerros neonatos é comprovadamente uma das principais causas de perdas econômicas em rebanhos de corte em diversos estados brasileiros (BARBOSA et al., 1998; BENESI, 1999; MOTA et al., 2000), determinando significativas morbidade e mortalidade (OLIVEIRA FILHO et al., 2007). Os prejuízos são diretamente derivados da redução do ganho de peso e dos custos com tratamento (LANGONI et al., 2004).

Enteropatógenos de origem bacteriana, parasitária e viral podem estar envolvidos de maneira isolada ou em associação na etiologia das diarréias neonatais bovinas (OLIVEIRA FILHO et al., 2007). Os vírus mais frequentemente apontados são coronavírus e rotavírus (BRANDÃO et al., 2007; OLIVEIRA FILHO et al., 2007; TAKIUCHI et al., 2006; ALFIERI et al., 2004; BUZINARO et al., 2003; ATHANASSIOUS et al., 1994).

Considerando-se as bactérias, destacam-se E. coli e Salmonela spp (OLIVEIRA FILHO et al., 2007; LANGONI et al., 2004; SALVADORI et al., 2003; GARCÍA et al., 2000; DE LA FUENTE et al., 1998; SNODGRASS et al., 1986).

Participantes no desencadeamento de diarréia neonatal bovina em sistemas de bovinocultura de corte, as endoparasitoses são um dos fatores determinantes na queda do desempenho dos animais e, conseqüentemente, na rentabilidade do sistema produtivo (JÄGER et al., 2005). Os enteroparasitas mais freqüentemente associados à diarréia em bezerros são os do gênero Cryptosporidium spp (OLIVEIRA FILHO et al., 2007; O’HANDLEY, 2007; KVÁC; KOUBA; VÍTOVEC, 2006; LANGONI et al., 2004; XIAO; HERD, 1994), Eimeria spp (FAGAN; DWYER; QUINLAN, 1995) e Giardia spp (XIAO; HERD, 1994).

Entretanto, apesar de todo o exposto já foi descrita a presença de potenciais enteropatógenos em bezerros neonatos clinicamente sadios (OLIVEIRA FILHO et al., 2007; O'HANDLEY, 2007), o que demonstra a complexidade da etiologia da diarréia neonatal (ALFIERI et al., 2004).

Além disso, a dificuldade no diagnóstico preciso da etiologia das enterites transmissíveis advém dos sinais clínicos freqüentemente inespecíficos, do envolvimento de múltiplos agentes etiológicos, da presença de portadores 
assintomáticos e, especialmente, da interação de fatores intrínsecos e extrínsecos que podem predispor à doença (ATHANASSIOUS et al., 1994).

Embora se reconheça a complexidade da síndrome diarréia em bezerros e os prejuízos por ela causados em bovinocultura de corte, permanecem escassos os estudos que se destinem à identificação em conjunto dos enteropatógenos envolvidos nessa síndrome (OLIVEIRA FILHO et al., 2007; JÄGER et al., 2005; BUZINARO et al., 2003; SALVADORI et al., 2003).

Os coronavírus pertencem à ordem Nidovirales, à família Coronaviridae e ao gênero Coronavirus, sendo vírus pleomórficos, aproximadamente esféricos, envelopados com até 220nm (MASTERS, 2006).

O genoma do coronavírus bovino (BCoV) é constituído por um RNA de fita simples, não segmentado, de sentido positivo, com $32 \mathrm{~kb}$, o qual, em associação com a fosfoproteína $\mathrm{N}$, origina um nucleocapsídeo de estrutura helicoidal (MASTERS, 2006).

O coronavírus bovino (BCoV) possui um envelope constituído por duas camadas de lipídios transfixadas por cinco proteínas estruturais (M, S, HE e I). Dentre elas, a principal é a proteína $S$ (espícula), anteriormente chamada E2. Esta é responsável pela atividade hemaglutinante, sendo o principal alvo para anticorpos neutralizantes; é constituída por um ectodomínio (subunidade S1) e um endodomínio (subunidade S2) (COLLINS et al., 1982).

A subunidade carbóxi-terminal $\$ 2$ forma a haste da espícula, responsável pela fusão de membranas e formação de sincícios (MASTERS, 2006).

Por sua vez, a subunidade $\mathbf{S 1}$, ectodomínio aminoterminal da proteína $\mathrm{S}$, muito mais variável do que a subunidade $\$ 2$, apresenta atividade de ligação a receptores celulares e forma o bulbo da espícula dos coronavírus (MASTERS, 2006). Por formar a porção bulbar da proteína $S$ que contém a maior parte dos sítios antigênicos, a subunidade S1 e o segmento do genoma dos coronavírus que a codifica são mais expostos a pressões seletivas imunológicas e, assim, mais propensos ao encontro de polimorfismos do que os demais genes e proteínas dos coronavírus (ABRAHAM et al., 1990).

O BCoV replica-se nos vilos das células absortivas do intestino delgado e em células não diferenciadas das criptas do cólon, resultando em descamação, encurtamento dos vilos e diarréia mal-absortiva. Este vírus é apontado como importante causa de diarréia em bezerros (FAGAN; DWYER; QUINLAN, 1995; 
SNODGRASS et al., 1986) e sua ocorrência já foi relatada em rebanhos de corte e de leite no Brasil (TAKIUCHI et al., 2006; MÉDICl et al., 2001 e JEREZ et al., 2002).

A importância do $\mathrm{BCoV}$, associado a outros enteropatógenos, na etiologia de distúrbios entéricos em bezerros de corte, é um fato comprovado para o rebanho brasileiro (OLIVEIRA FILHO et al., 2007), motivando e ressaltando a importância do projeto ora proposto.

Além disso, existe um significante lacuna no que se refere a estudos genômicos a respeito das linhagens de BCoV que infectam bezerros de corte no Brasil. Neste sentido, o seqüenciamento parcial do gene codificador da subunidade S1 da proteína de espícula (S), poderia contribuir para a classificação das linhagens genéticas do vírus, bem como para a investigação de marcadores de virulência dos mesmos.

Os rotavírus, patógenos virais também envolvidos com elevada freqüência em diarréias neonatais de bovinos, pertencem à família Reoviridae, gênero Rotavirus. São vírus não envelopados e o genoma viral é formado por 11 segmentos de RNA fita dupla (dsRNA) sentido negativo, envolvido por um núcleo (core) protéico composto por três glicoproteínas virais (VP, viral proteins): VP1, VP2 e VP3 (ALFIERI et al., 2004).

Baseando-se neste arranjo de RNA com 11 segmentos, a técnica laboratorial mais utilizada para a detecção de rotavírus é a eletroforese em gel de poliacrilamida (PAGE), na qual se busca evidenciar a presença dos 11 segmentos de RNA dos rotavírus diretamente de extratos de RNA de amostras fecais (HERRING et al., 1982), sendo esta uma técnica de alta especificidade analítica.

Nos rotavírus, cada segmento genômico codifica, pelo menos, um polipeptídeo, sendo seis proteínas estruturais e cinco não estruturais (ESTES; KAPIKIAN, 2007).

Acima do core, existe um capsídeo duplo composto por uma camada tripla de proteínas, denominadas: VP6 (capsídeo interno) e VP7 e VP4 (capsídeo externo). Em contato com o "core" e transfixando o capsídeo externo, localiza-se a proteína VP4.

A proteína VP6 permite a classificação dos rotavírus em 7 sorogrupos/espécies ( $A, B, C, D, E, F, G$ e H), distinguíveis por eletroforétipos característicos. As espécies, ou sorogrupos, de rotavírus são distinguíveis ainda em sorotipos, de acordo com as proteínas VP4 e VP7 (ESTES; KAPIKIAN, 2007). 
Os rotavírus têm sido apontados como importantes agentes causadores de diarréias agudas em bezerros, especialmente os pertencentes ao sorogrupo $A$, mas com grande variedade sorotípica (ALFIERI et al., 2004; BUZINARO et al., 2003; ATHANASSIOUS et al., 1994; SNODGRASS et al., 1986). Considerando a implicação dos rotavírus na etiologia da diarréia neonatal dos bovinos, estudos que colaborem com o entendimento do impacto causado pelo mesmo em se tratando de bovinos de corte no Brasil constituem significativa colaboração, dada a necessidade de contínuo monitoramento para o delineamento de programas de profilaxia para as rotaviroses (ALFIERI et al., 2004; BUZINARO et al., 2003).

A Escherichia coli é um integrante da microbiota entérica natural de mamíferos (humanos, inclusive). Caracteriza-se por ser um bastonete Gramnegativo, e a diferenciação entre cepas inócuas e cepas patogênicas depende da produção de fatores de virulência: toxinas e fatores de colonização (SALVADORI et al., 2003).

As cepas patogênicas de E. coli são capazes de produzir um ou mais fatores de virulência, divididos em dois grupos: fímbrias (ou pili) e enterotoxinas (OK et al., 2009). Entre as enterotoxinas destacam-se: toxinas Shiga-like (Stx), enterotoxinas termolábeis (LT) e termoestáveis (ST), fatores citotóxicos de necrose (CNF1 e CNF2) e hemolisinas (a-Hly e E-Hly), (MOURA, 2005). As fímbrias, K99 ou, mais modernamente, F5, (MOXLEY; SMITH, 2010) e F41, são responsáveis pela aderência bacteriana ao íleo, atuando como fatores de colonização (OK et al., 2009).

Cepas de E. coli capazes de produzir enterotoxinas termolábeis (LT-I e LT-II) e enterotoxinas termoestáveis (Sta e STb) são classificadas como E.coli enterotoxigênicas (ETEC), enquanto as cepas produtoras de fatores de necrose celular (CNF1 e CNF2) são denominadas E. coli necrotizantes (SALVADORI et al., 2003). Além dessas, as cepas produtoras das toxinas Stx1 e Stx2 são classificadas como E. coli produtoras de toxina shiga-like (STEC). Por fim, há cepas capazes de produzir lesões adesão e invasão, conhecidas como attaching-effacing $E$. coli (AEEC). As cepas capazes de produzir eae e St têm sido classificadas como E. coli enterohemorrágicas (EHEC), (OK et al., 2009), sendo essas associadas a casos de colite hemorrágica $(H C)$ e síndrome urêmica hemolítica (HUS) em humanos (SALVADORI et al., 2003).

A Escherichia coli está entre os enteropatógenos mais freqüentemente isolados em bezerros com diarréia (LANGONI et al., 2004; SALVADORI et al., 2003) 
e clinicamente sadios, ratificando a importância da investigação de fatores de virulência no esclarecimento da patogenia dos quadros de diarréia (OLIVEIRA FILHO et al., 2003).

As Salmonella spp, também bactérias Gram-negativas, são enteropatógenos cuja participação já foi relatada em distúrbios entéricos de bezerros (LANGONI et al., 2004; SNODGRASS et al., 1986), ainda que possam estar ausentes em casos de diarréia neonatal bovina (OLIVEIRA FILHO et al., 2007; MOTA et al., 2000; FAGAN et al., 1995).

Todavia, o diagnóstico da salmonelose deve ser sempre considerado em bezerros com distúrbios entéricos, devido à gravidade das manifestações e ao risco para evolução a processos septicêmicos relacionados a esse enteropatógeno (OLIVEIRA FILHO et al., 2007).

Destacando-se entre os processos patológicos entéricos de etiologia parasitária, a criptosporidiose é apontada como uma das principais causas de diarréia em bezerros neonatos (OLIVEIRA FILHO et al., 2007; O'HANDLEY, 2007; KVÁC; KOUBA, VÍTOTEC, 2006; XIAO; HERD, 1994), o que justifica a investigação de oocistos de Cryptosporidium spp, em fezes de bezerros com diarréia.

Todas as espécies do gênero Cryptosporidium caracterizam-se como parasitas intracelulares obrigatórios. A evolução dos estágios de vida, dentro das células do hospedeiro, culmina com a eliminação da forma encistada (oocisto) desse protozoário, juntamente com as fezes (FAYER; MORGAN; UPTON, 2000).

A espécie mais freqüentemente relatada nos casos de diarréia em bezerros neonatos é C. parvum, com altas taxas $\mathrm{e}$ intensidade de infecção, concomitantemente com outros enteropatógenos (OLSON et al., 2004; FAYER; MORGAN; UPTON, 2000). Ainda, o C. andersoni infecta o abomaso de bovinos jovens e adultos, mas com reduzidas intensidade e taxa de infecção (OLSON et al., 2004).

Similarmente ao que ocorre com Cryptosporidium, em diversos locais do mundo têm sido detectada Giardia duodenalis em bovinos de corte e leite. A infecção de bezerros decorre do contato com outros bezerros e/ou do contato com bovinos adultos portadores de infecções crônicas (OLSON et al., 2004).

Uma excreção de quantidades significativas de cistos de Giardia spp. por bezerros ocorre entre a $5^{\mathrm{a}}$ e $6^{\mathrm{a}}$ semanas de vida (OLSON et al., 2004). A infecção por Giardia spp, associada à infecção por outros enteropatógenos, desempenha um 
papel importante na etiologia das enterites em bezerros neonatos (XIAO; HERD, 1994).

Existem, ainda, diversos outros enteroparasitas significativos em bezerros de corte, tais como Stongyloides pappillosos (cujo ciclo galactogênico aumenta a relevância em animais neonatos) e Eimeria spp. (cuja incidência acumulada pode chegar a 100\%) (FABER et. al., 2002).

Existem mais de 20 espécies de Eimeria spp capazes de infectar bovinos, entretanto, 2 espécies em particular exibem maior patogenicidade, a Eimeria bovis e a Eimeria zurneii, especialmente em animais jovens. Adicionalmente, a Eimeria alamensis também já foi apontada como uma espécie patogênica (DAUGSHIES; NAJDROWSKI, 2005).

Após a exposição a esse coccídio, ocorre, rapidamente, o desenvolvimento de imunidade tanto humoral quanto celular, mas sua intensidade depende da dose infectante. Entretanto, não ocorre imunidade absoluta, fazendo com que mesmo os animais mais velhos excretem oocistos desse parasita, contribuindo para a manutenção endêmica do parasita (DAUGSHIES; NAJDROWSKI, 2005).

Por fim, pequenas quantidades de ovos de estrogilídeos, em um número reduzido de amostras de fezes provenientes de bezerros com diarréia, já foram também relatados no Brasil (LANGONI et al., 2004), mas de modo variável, dependendo da intensidade do uso de anti-helmínticos no rebanho (OLIVEIRA FILHO et al., 2007).

Pelo exposto, fica evidente a complexidade da etiologia da diarréia neonatal dos bovinos, a qual se constitui em uma síndrome de ainda incipiente investigação considerando-se o rebanho de corte brasileiro, bem como do impacto negativo que tal síndrome gera para a produtividade da pecuária, mostrando-se um campo de pesquisa em aberto para exploração. 
HIPÓTESE E OBJETIVOS 


\section{HIPÓTESE E OBJETIVOS}

\subsection{HIPÓTESE}

A diversidade e freqüência de ocorrência de potenciais enteropatógenos aumentam com a idade em bezerros de corte, podendo a freqüência ser influenciada por condições de manejo.

\subsection{OBJETIVOS}

2.2.1 Estudar de modo longitudinal a freqüência de ocorrência de coronavírus bovino, rotavírus do grupo $\mathrm{A}$, protozoários, helmintos e enterobactérias em bezerros de corte.

2.2.2 Investigar os patotipos de E. coli que ocorrem em bezerros de corte.

2.2.3 Avaliar a associação entre a freqüência de enteropatógenos e o manejo sanitário $\mathrm{m}$ fazendas de gado de corte. 
MATERIAIS E MÉTODOS 


\section{MATERIAIS E MÉTODOS}

\subsection{COLHEITA DE AMOSTRAS FECAIS}

\subsubsection{Propriedades amostradas}

Foram colhidas amostras fecais de bezerros de corte (Bos taurus indicus) provenientes de duas fazendas: uma com casos esporádicos de diarréia, localizada em Pirassununga - SP, e outra fazenda com casos recorrentes, localizada em Descalvado - SP.

Em ambas as propriedades os animais são mantidos a pasto, sendo que todos os bezerros neonatos recebem tratamento do umbigo com iodo a $10 \%$ e tratamento em dose única com antiparasitário da classe das lactonas macrocíclicas, conforme recomendação do fabricante do medicamento utilizado.

\subsubsection{Propriedade com casos esporádicos}

Na propriedade com casos esporádicos da doença (Sistema de Bovinocultura de Corte da Coordenadoria do Campus de Pirassununga (CCPS) da Universidade de São Paulo) praticam-se: identificação dos bezerros pelo uso de brincos e tatuagem na orelha, medidas de manejo com atenção ao bem-estar animal, separação de lotes respeitando-se as diferentes categorias animais, a rotação de pastagem, suplementação mineral com premix comum na estação de chuvas e com premix mineral proteinado na estação seca e realização de estação de monta controlada.

Os animais provenientes da fazenda de Pirassununga eram todos da raça Nelore. 
A colheita das amostras nesta fazenda ocorreu entre setembro de 2008 e junho de 2009, tendo sido realizada em 30 animais. Por haver uma estação definida de parição, foi possível realizar as colheitas em acordo com faixas etárias definidas: $1^{\mathrm{a}}, 8^{\mathrm{a}}$ e $12^{\mathrm{a}}$ semanas de vida e uma última coleta no momento da desmama dos animais, conforme Figura 1.

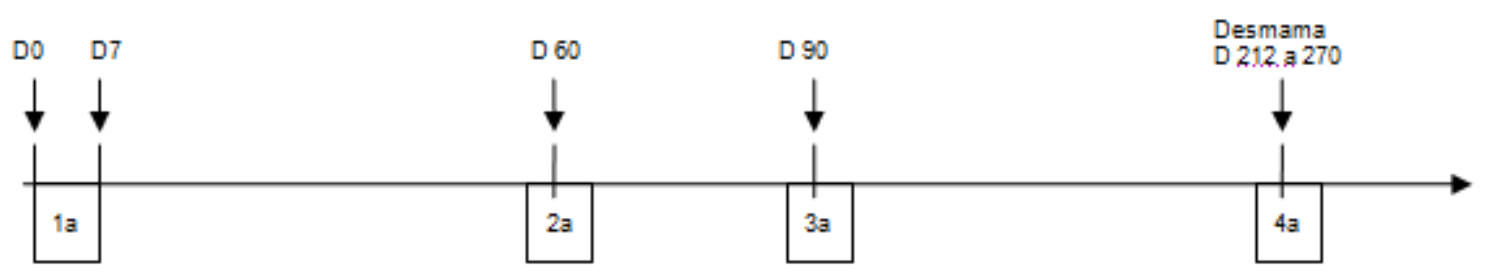

Figura 1 - Apresentação esquemática da coleta de amostras na fazenda do campus da USP de Pirassununga

\subsubsection{Propriedade com casos recorrentes}

$\mathrm{Na}$ propriedade com casos recorrentes de diarréia (Descalvado - SP,) há restrição de pastagens disponíveis, razão pela qual não se pratica a divisão das diferentes categorias animais em lotes distintos, nem a rotação de pastagens. Além disso, existe a necessidade de suplementação de alimento em cocho, adicionalmente à suplementação com premix mineral comum. Nessa propriedade, ainda, não há estação de monta planejada, ocorrendo parição durante o ano todo. Para a realização do estudo, doze animais foram identificados visualmente pelo tratador, por serem bezerros filhos de reprodutoras da propriedade, e dezenove animais receberam brincos numerados para identificação.

Esta propriedade possui rebanho misto, composto por animais da raça Nelore e animais cruzados (Nelore x Guzerá x Gir), tendo sido colhidas amostras de animais de raça e animais cruzados.

Desta fazenda, investigaram-se 31 animais, entre setembro de 2009 e março de 2010. Entretanto, a ausência de estação definida de parição impediu a formação de lotes de colheita com faixa etária homogênea. 


\subsubsection{Definição de caso}

Foi adotada como definição de caso de diarréia a eliminação de fezes de consistência diminuída, presença de fezes na região perianal e/ou aumento na freqüência de evacuações, conforme observado no momento da colheita ou relatado pelo médico veterinário responsável pela fazenda ou pelo tratador dos animais.

\subsubsection{Procedimentos para colheita, transporte e armazenamento de amostras}

A colheita de fezes foi realizada com auxílio de sacos plásticos limpos (para exame parasitológico e virológico) e swab estéril (para exame microbiológico), diretamente da ampola retal de cada animal, conforme Figura 2.

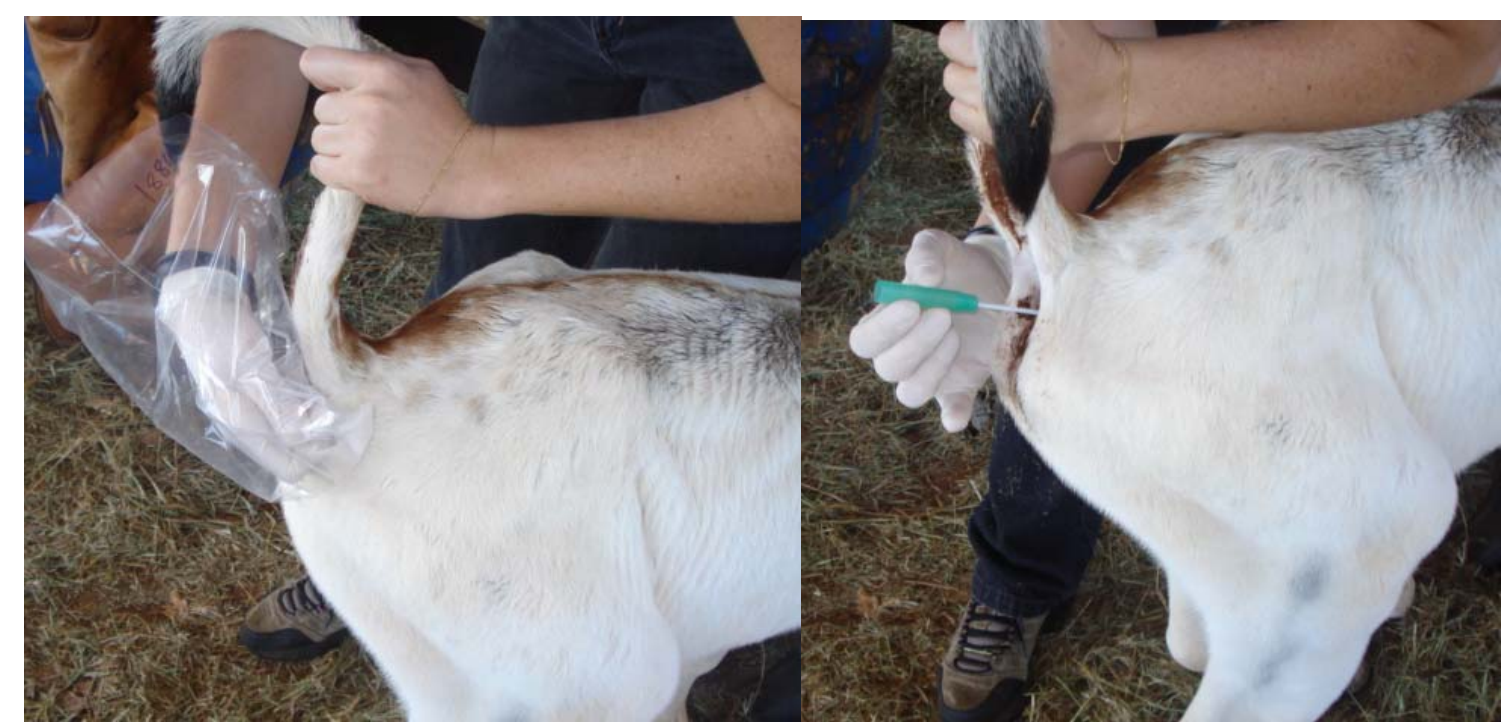

Figura 2 - Coleta de amostra fecal da ampola retal de bezerros com cerca de uma semana de vida: conteúdo fecal (à esquerda) e swab (à direita) 
As amostras foram imediatamente identificadas e conservadas sob refrigeração (cerca de $4^{\circ} \mathrm{C}$ ), sendo o transporte ao laboratório realizado no mesmo dia da coleta (Figura 3).

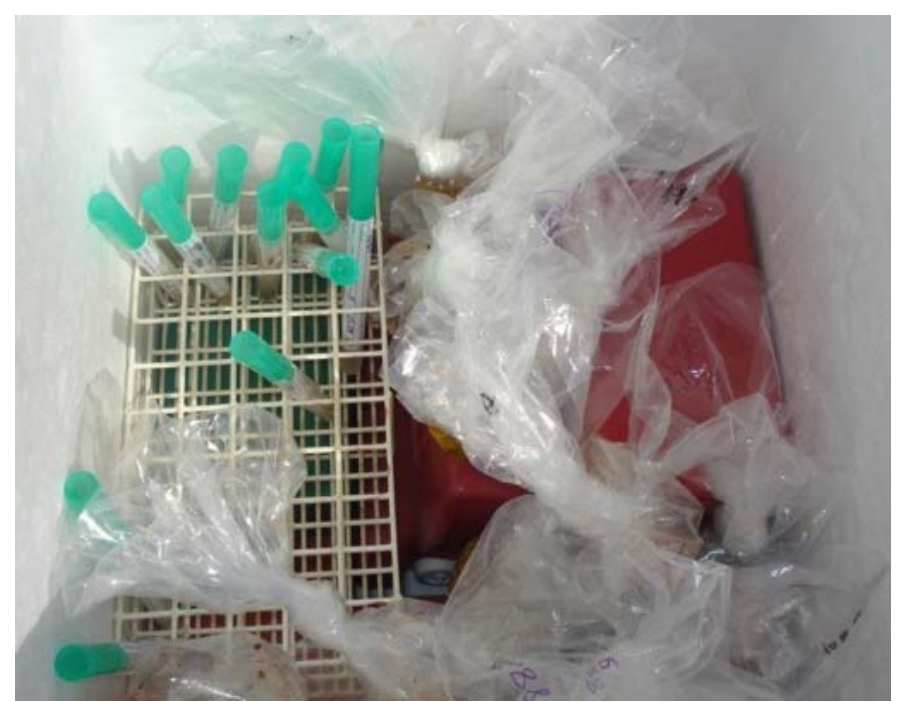

Figura 3 - Amostras coletadas mantidas em recipiente isolante e mantidas sob refrigeração

No Laboratório de Biologia Molecular Aplicada e Sorologia (LABMAS- VPS FMVZ - USP, Campus São Paulo), os swabs foram imediatamente armazenados em geladeira $\left(4^{\circ} \mathrm{C}\right)$ e as amostras fecais foram aliquotadas para exame coproparasitológico e virológico, dentro de um período máximo de vinte e quatro horas.

As alíquotas para exame coproparasitológico foram armazenadas em coletores universais esterilizados, constituindo uma suspensão a $50 \%$ em Bicromato de Potássio a $2 \%$ e conservadas sob refrigeração $\left(4^{\circ} \mathrm{C}\right)$.

Alíquotas para exame virológico foram acondicionadas em tubos tipo eppendorff $^{\circledR}$ de $1,5 \mathrm{~mL}$, constituindo suspensões em água tratada com $0,1 \%$ de dietilpirocarbonato (água DEPC), segundo o quadro 1 , e armazenadas a $-18^{\circ} \mathrm{C}$.

\begin{tabular}{|c|c|c|}
\hline $\begin{array}{c}\text { Estado da } \\
\text { amostra }\end{array}$ & \% Amostra & \% Água DEPC \\
\hline Líquida & 100 & 0 \\
\hline Pastosa & 50 & 50 \\
\hline Consistente & 20 & 80 \\
\hline
\end{tabular}

Quadro 1 - Critério utilizado para diluição das alíquotas fecais para exame virológico 
As suspensões assim diluídas foram homogeneizadas por 15 segundos, com auxílio de vórtex, e mantidas em geladeira $\left(4^{\circ} \mathrm{C}\right)$ por 10 minutos, tendo-se repetido esse procedimento 3 vezes. Após esse procedimento as amostras foram clarificadas a $5.000 \times$ g por 15 minutos a $4^{\circ} \mathrm{C}$, tomando-se o sobrenadante como amostra para o exame virológico.

Abaixo, está apresentado um fluxograma dos procedimentos adotados para cada amostra (Figura 4):

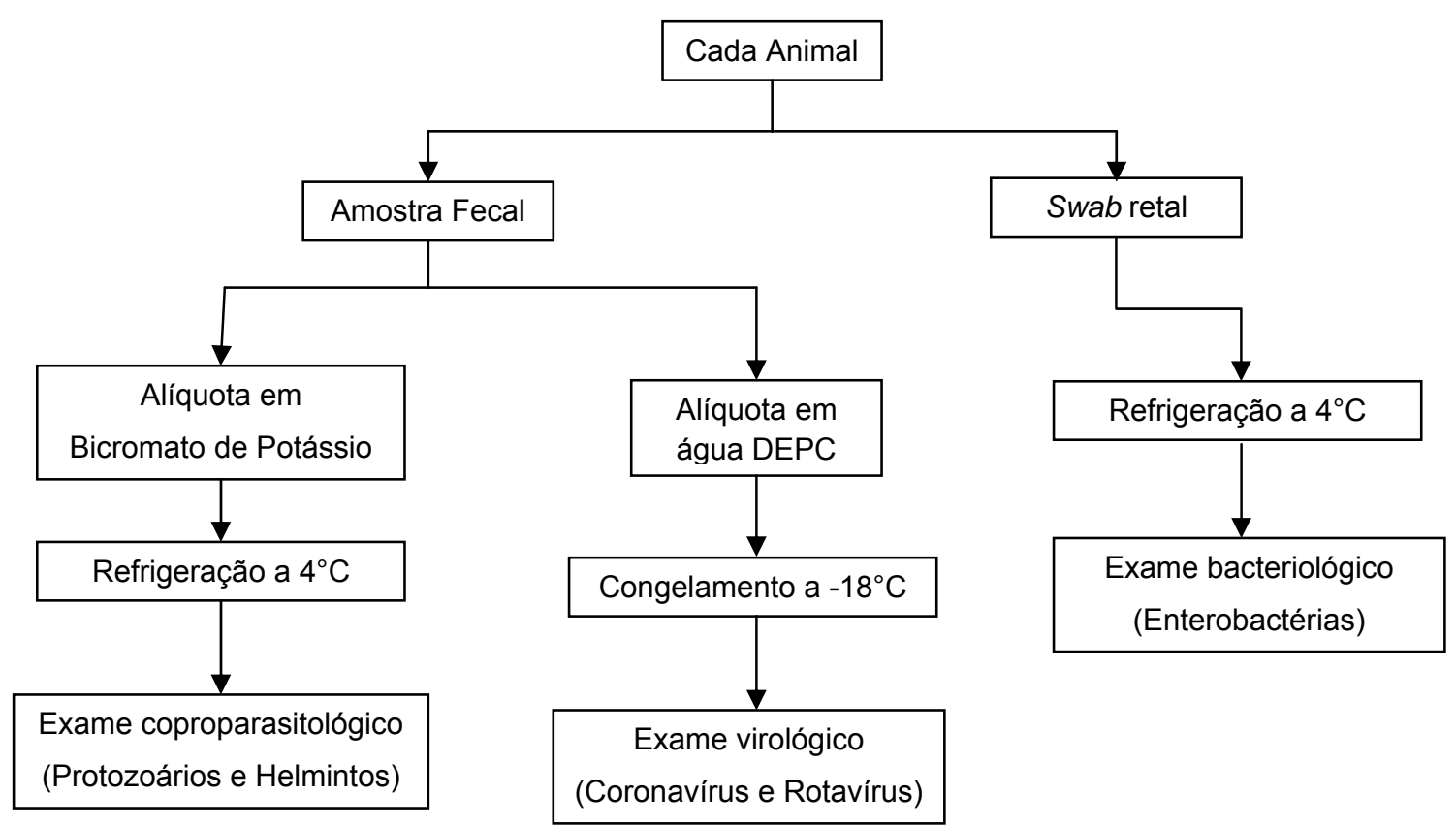

Figura 4 - Fluxograma dos procedimentos realizados para obtenção de amostras e respectivas alíquotas 


\subsection{DETECÇÃO E IDENTIFICAÇÃO DE ENTEROBACTÉRIAS}

A detecção de enterobactérias seguiu os procedimentos descritos por Krieg e Holt (1986), com algumas adaptações. Com o intuito de aprimorar a qualidade do material para cultivo, optou-se pela utilização de swab estéril em tubo contendo $3 \mathrm{~mL}$ de meio de Stuart (Transporte Bacteriológico Stuart Agar Gel - CB Products ${ }^{\circledR}$ ) para colheita e conservação até o processamento, ao invés da utilização de fezes frescas. Os swabs foram processados em um tempo máximo de 30 dias no Laboratório de Bacteriologia e Micologia (LBM - VPS - FMVZ - USP, Campus São Paulo).

No primeiro dia de processamento, realizou-se a pré-cultura dos swabs em meio $\mathrm{BHI}$ (Brain Heart Infusion) a $37^{\circ} \mathrm{C}$ por $24 \mathrm{~h}$. Neste mesmo dia, os swabs foram estriados em Agar MacConkey e, também, incubados a $37^{\circ} \mathrm{C}$ por 24 e $48 \mathrm{~h}$, com leitura das placas semeadas após estes períodos para caracterização das colônias quanto a seu aspecto macroscópico.

Cada colônia morfologicamente distinta foi, então, cultivada individualmente em meio $\mathrm{BHI}$, a $37^{\circ} \mathrm{C}$ por $24 \mathrm{~h}$. Após esse período, com auxílio de uma haste bacteriológica, os produtos de cultivo foram submetidos a testes bioquímicos / metabólicos seguindo o método descrito por Holt et al. (1994) adaptado à rotina diagnóstica do laboratório. Estes testes abrangeram os seguintes meios de prova: Triple Sugar Iron (TSI), Indol, Citrato, Malonato, Lactose, Glicose, Fenilalanina e Agar Semi-sólido. Nos casos em que as provas anteriormente descritas não foram suficientes para a identificação da colônia realizou-se adicionalmente a prova da urease.

Adicionalmente, também no primeiro dia de processamento realizou-se, a semeadura dos swabs em meio XLT4, para favorecer o crescimento de Salmonella spp. As colônias isoladas por este método e que apresentaram aspecto morfológico sugestivo de Salmonella spp (colônias rosadas e/ou com produção de ácido sulfídrico) foram submetidas ao mesmo método de identificação, já descrito.

A Figura 5 apresenta um fluxograma do processamento de cada swab: 


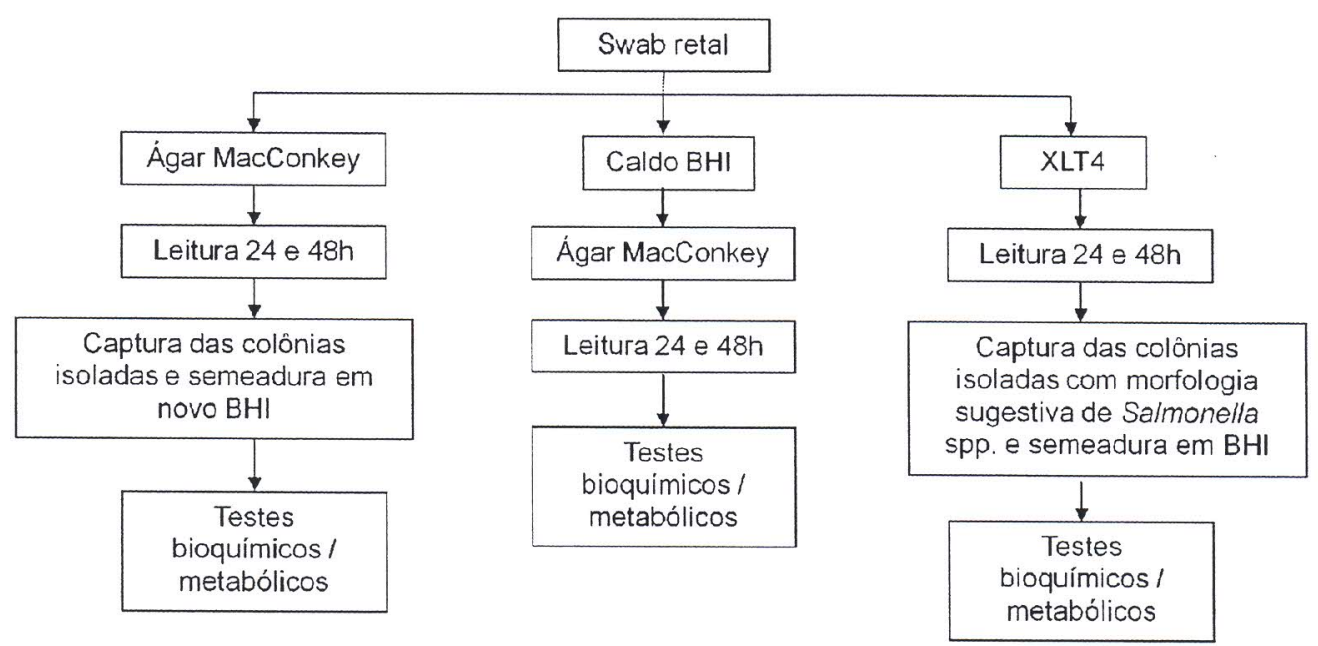

Figura 5 - Fluxograma dos procedimentos realizados para diagnóstico bacteriológico

Todas as colônias isoladas foram armazenadas em palhetas para congelamento em botijão de nitrogênio líquido $\left(-196^{\circ} \mathrm{C}\right)$, em meio $\mathrm{BHI}$ com $5 \%$ de glicerol, para aumento da coleção de bactérias do LBM. Além disso, esse foi o método utilizado para conservação das Escherichia coli, para posterior investigação de fatores de virulência.

\subsection{DETECÇÃO DE FATORES DE VIRULÊNCIA DE Escherichia coli}

A virulência das Escherichia coli isoladas foi investigada através de uma Multiplex-PCR utilizando pares de primers destinados à detecção dos genes codificadores dos seguintes fatores de virulência: intimina (eae), K99, F41, toxina Shiga like dos tipos 1 e 2 (Stx1 e Stx2, respectivamente), e toxina termo-estável do tipo a (Sta) (OK et al., 2009). No Quadro 2 estão apresentadas as seqüências de nucleotídeos dos primers utilizados, bem como os respectivos tamanhos de fragmentos amplificados esperados. 


\begin{tabular}{|c|c|c|}
\hline Gene & Seqüência (5'-3') & Amplicon (pb) \\
\hline Stx1 $(F)$ & TTC GCT CTG CAA TAG GTA & \multirow{2}{*}{555} \\
\hline Stx1 (R) & TTC CCC AGT TCA ATG TAA GAT & \\
\hline Intimina $(F)$ & ATA TCC GTT TTA ATG GCT ATC T & \multirow{2}{*}{425} \\
\hline Intimina (R) & AAT CTT CTG CGT ACT GTG TTC A & \\
\hline $\mathrm{F} 41(\mathrm{~F})$ & GCA TCA GCG GCA GTA TCT & \multirow{2}{*}{380} \\
\hline F41 (R) & GTC CCT AGC TCA GTA TTA TCA CCT & \\
\hline K99 (F) & TAT TAT CTT AGG TGG TAT GG & \multirow{2}{*}{314} \\
\hline K99 (R) & GGT ATC CTT TAG CAG CAG TAT TTC & \\
\hline Sta $(F)$ & GCT AAT GTT GGC AAT TTT TAT TTC TGT A & \multirow{2}{*}{190} \\
\hline Sta $(\mathrm{R})$ & AGG ATT ACA ACA AAG TTC ACA GCA GTA A & \\
\hline Stx2 (F) & GTG CCT GTT ACT GGG TTT TTC TTC & \multirow{2}{*}{118} \\
\hline Stx2 (R) & AGG GGT CGA TAT CTC TGT CC & \\
\hline
\end{tabular}

Quadro 2 - Genes codificadores de fatores de virulência de E. coli investigados pela mulptiplex-PCR com seus respectivos primers para amplificação no sentido 5'-3' ( $F$ - foward) e no sentido 3'-5' ( $R$ - reverse) e os respectivos tamanhos de fragmento esperados, em pares de bases $(\mathrm{pb})$

Como controle positivo foram utilizadas duas amostras padrão de E. coli denominadas EDL33 (contendo os genes codificadores para Stx1, Stx2 e Intimina) e B41 (contendo os genes codificadores para Sta, F41 e K99), gentilmente cedidas pelo Prof. Dr. Marcos Bryan Heinemann (Universidade Federal de Minas Gerais). Como controle negativo foi utilizada água ultra-pura, adicionando-se um tubo para controle negativo a cada 5 amostras.

As palhetas de congelamento contendo as colônias previamente congeladas em $\mathrm{BHI}$ acrescido de $5 \%$ de glicerol foram retiradas do nitrogênio líquido e mantidas em geladeira $\left(4^{\circ} \mathrm{C}\right)$ para descongelamento de seu conteúdo. O conteúdo da palheta foi transferido para um tubo de ensaio contendo meio de cultivo $\mathrm{BHI}$ e incubado a $37^{\circ} \mathrm{C}$ por $24 \mathrm{~h}$ para crescimento bacteriano. Passado esse período, coletaram-se $20 \mu \mathrm{L}$ do meio de cultivo contendo E. coli e adicionaram-se a $180 \mu \mathrm{L}$ de tampão Tris $10 \mathrm{mM}$ - EDTA $1 \mathrm{mM}$ (TE) $\mathrm{pH}=8,0$, previamente acondicionados em um tubo tipo eppendorff de $1,5 \mathrm{~mL}$, e essa solução foi destinada à extração de DNA. 
Para a extração de DNA, a solução foi homogeneizada com auxílio de vórtex por 10 segundos e incubada a $99^{\circ} \mathrm{C}$, em banho seco, durante 10 minutos. Em seguida, transferiram-se os tubos para banho de gelo, no qual permaneceram por 15 minutos. Por fim, centrifugaram-se as soluções a 12.000 x g por 1 minuto e, com auxílio de pipetador, coletaram-se $140 \mu \mathrm{L}$ de sobrenadante, transferidos para um novo tubo como amostra.

Para a realização da multiplex-PCR, 2,6 $\mu \mathrm{L}$ de DNA total extraído foram adicionados ao mix de reação contendo: 1 x PCR Buffer (Invitrogen ${ }^{\mathrm{TM}}$ ), 0,2mM de cada dNTP, 0,5 $\mu \mathrm{M}$ de cada primer (Quadro 2), 1,5mM $\mathrm{MgCl}_{2}, 1,25 \mathrm{U}$ Taq platinum DNA polimerase (Invitrogen ${ }^{\mathrm{TM}}$ ), para uma reação final de $25 \mu \mathrm{L}$. A solução final foi submetida aos ciclos apresentados no Quadro 3.

\begin{tabular}{|c|c|c|}
\hline Passo & $\begin{array}{c}\text { Temperatura } \\
\left({ }^{\circ} \mathbf{C}\right)\end{array}$ & Tempo \\
\hline 1 & 94 & $3 \mathrm{~min}$ \\
\hline 2 & 95 & $30 \mathrm{~s}$ \\
\hline 3 & 50 & $45 \mathrm{~s}$ \\
\hline 4 & 70 & $1 \mathrm{~min}$ \\
\hline 5 & Repetir 24 vezes do passo 2 ao passo 4 \\
\hline 6 & 70 & $10 \mathrm{~min}$ \\
\hline
\end{tabular}

Quadro 3 - Ciclos de temperatura com seus respectivostempos de duração para a realização de Mutiplex-PCR para detecção de genes codificadores de fatores de virulência de E. coli (OK et al., 2009)

Dez microlitros do produto de reação foram analisados em eletroforese em gel de agarose $1,5 \%$ corado com brometo de etídeo a $0,5 \mu \mathrm{L} / \mathrm{mL}$ e observado sob luz ultravioleta, sendo consideradas positivas as amostras que demonstraram produtos amplificados de tamanhos previstos no Quadro 2.

\subsection{PESQUISA DE PROTOZOÁRIOS E HELMINTOS}

As alíquotas reservadasao exame coproparasitológico, conforme previamente descrito, foram processadas no Laboratório de Doenças Parasitárias (LDP - VPS FMVZ - USP, Campus São Paulo). 
Para a detecção de oocistos e cistos de protozoários e ovos de helmintos, realizou-se o exame parasitológico pelo método de centrífugo-sedimentação em água-éter (FERREIRA et al., 1962), também conhecido como método de Ritchie. Como a presença de gordura nas fezes de lactentes pode prejudicar a visualização de estruturas pequenas, o método de Ritchie foi utilizado, ainda, para clarificar as amostras que foram posteriormente submetidas à técnica de centrífugo-flutuação em solução supersaturada de sacarose, densidade 1,2g/cm ${ }^{3}$ (OGASSAWARA; BENASSI, 1980; LALLO, 1993), técnica também conhecida como método de Sheater. Vale lembrar que o método de Sheater permite, inclusive, a identificação de protozoários pertencentes ao gênero Cryptosporidium spp (DUBEY et al., 1990).

A Figura 6 apresenta um fluxograma dos procedimentos adotados:

Figura 6 - Fluxograma dos procedimentos realizados para diagnóstico parasitológico: método de Sheather modificado (à esquerda) e método de Ritchie modificado (à direita) 
As amostras foram classificadas, quanto à presença de cada parasita, segundo a quantidade de estruturas parasitárias observadas na maioria dos campos examinados à microscopia ótica ( $50 \%$ ou mais), conforme apresentado no Quadro 4:

\begin{tabular}{|c|c|}
\hline $\begin{array}{c}\text { Classificação } \\
\text { da amostra }\end{array}$ & $\begin{array}{c}\text { Oocistos / Cistos / Ovos } \\
\text { por Campo (250\%) }\end{array}$ \\
\hline raros & $<1$ \\
\hline$(+)$ & 1 \\
\hline$(++)$ & 2 \\
\hline$(+++)$ & 3 \\
\hline$(++++)$ & 4 \\
\hline
\end{tabular}

Nos casos em que houver divergência dos resultados obtidos em cada uma das técnicas empregadas, será considerado como resultado final o conjunto de parasitas encontrado em ambas, e nos casos em que houver diferença na quantificação dos parasitas, será considerado o maior escore encontrado.

\subsection{PESQUISA DE CORONAVÍRUS BOVINO (BCOV)}

A pesquisa de coronavírus bovino foi realizada utilizando-se uma reação de transcrição reversa seguida por reação em cadeia pela polimerase em nested (nested-RT-PCR) dirigida à amplificação de um segmento de 136 pares de bases da ORF1b, codificadora da RNA-polimerase RNA-dependente viral (RdRp), segundo descrito por Brandão et al. (2005).

Como controle positivo, utilizou-se a amostra de referência de coronavírus bovino denominada amostra Kakegawa (AKASHI et al., 1980), mantida em cultura de células da linhagem HmLu (pulmão de hamster), com título hemaglutinante de 256. 
Como controle negativo, foi utilizada água tratada com $0,1 \%$ de dietilpirocarbonato (água DEPC), na proporção de 1 controle negativo para cada 5 amostras.

O RNA total foi extraído do das alíquotas reservadas para o exame virológico (conforme item 3.1.2) utilizando-se TRIzol Reagent (Invitrogen ${ }^{\mathrm{TM}}$ ) de acordo com as instruções do fabricante.

Para a realização da transcrição reversa $(\mathrm{RT})$, foram desnaturados $3,5 \mu \mathrm{L}$ do RNA extraído, submetendo-o a $95^{\circ} \mathrm{C}$ durante 5 minutos e adicionado ao mesmo o mix de transcrição reversa contendo: 1 x First Strand Buffer (Invitrogen ${ }^{\mathrm{TM}}$ ), $1 \mathrm{mM}$ de cada dNTP, 10mM DTT, 2,5ng de Random Hexamers (Invitrogen ${ }^{\mathrm{TM}}$ ), $100 \mathrm{U}$ de MMLV Reverse Transcriptase (Invitrogen ${ }^{\mathrm{TM}}$ ) e água-DEPC q.s.p. $10 \mu \mathrm{L}$, realizando-se a transcrição reversa a $42^{\circ} \mathrm{C}$ por 60 minutos.

Para a realização da PCR, um volume de $2,5 \mu \mathrm{L}$ de cDNA, produto da RT, foi adicionado ao mix de PCR contendo: 1 x PCR Buffer (Invitrogen ${ }^{\mathrm{TM}}$ ), 0,2mM de cada dNTP, 0,5 $\mu \mathrm{M}$ de cada primer 4Bm e 2Bp (Quadro 5), 1,5mM $\mathrm{MgCl}_{2}, 0,625 \mathrm{U}$ de Taq platinum DNA polimerase (Invitrogen ${ }^{\mathrm{TM}}$ ) e água DEPC para uma reação final de $25 \mu \mathrm{L}$, submetendo-se a solução a 6 ciclos de $94^{\circ} \mathrm{C} / 1$ minuto, $40^{\circ} \mathrm{C} / 2$ minutos e $72^{\circ} \mathrm{C} / 1$ minuto; 36 ciclos de $94^{\circ} \mathrm{C} / 1$ minuto, $50^{\circ} \mathrm{C} / 1,5$ minutos e $72^{\circ} \mathrm{C} / 1$ minuto; seguidos por um ciclo de $72^{\circ} \mathrm{C} / 10$ minutos para extensão final.

Por fim, procedeu-se a segunda amplificação (Nested), adicionando-se 2,5 $\mu \mathrm{L}$ do produto da primeira amplificação (PCR) ao mix de nested-PCR contendo: $1 \mathrm{x}$ PCR Buffer (Invitrogen ${ }^{T M}$ ), 0,2mM de cada dNTP, 0,5 $\mu \mathrm{M}$ de cada primer, CV2L e CV2U (quadro X), 1,5mM $\mathrm{MgCl}_{2}, 0,625 \mathrm{U}$ de Taq DNA polimerase (Invitrogen ${ }^{\mathrm{TM}}$ ) e água DEPC, para uma reação final de $25 \mu \mathrm{L}$, submetendo-se a solução final a 26 ciclos de $94^{\circ} \mathrm{C} / 1$ minuto, $54,8^{\circ} \mathrm{C} / 1,5$ minutos e $72^{\circ} \mathrm{C} / 1$ minuto seguidos de um ciclo de $72^{\circ} \mathrm{C} / 10^{\prime}$ para extensão final. 


\begin{tabular}{|c|c|c|c|}
\hline Primer & Seqüência (5' - 3') & $\begin{array}{l}\text { Amplicon } \\
\text { (pb) }\end{array}$ & Referência \\
\hline $4 \mathrm{Bm}$ & TCACAYTTWGGATARTCCCA & \multirow{2}{*}{251} & \multirow{2}{*}{$\begin{array}{c}\text { Stephensen et al., } \\
1999\end{array}$} \\
\hline 2Bp & ACTCARWTRAATYTNAAATAYGC & & \\
\hline CV2L & TACTATGACTGGCAGAATGTTTCA & \multirow{2}{*}{136} & \multirow{2}{*}{ Brandão et al., 2005} \\
\hline CV2U & AACATCTTTAATAAGGCGRCGTAA & & \\
\hline
\end{tabular}

Dez microlitros da reação de nested foram analisados por eletroforese em gel de agarose a $1,5 \%$, corado com brometo de etídeo $0,5 \mu \mathrm{g} / \mathrm{mL}$ e observado sob luz ultravioleta, sendo consideradas positivas as amostras que resultaram na banda de $136 \mathrm{pb}$.

\subsection{RT-PCR PARA A AMPLIFICAÇÃO DA REGIÃO CODIFICADORA DA SUBUNIDADE S1 DA PROTEÍNA S DE CORONAVÍRUS BOVINO}

As amostras positivas na PCR dirigida ao gene $R d R p$ foram submetidas a uma nova PCR, dirigida à amplificação de um segmento de 488 pares de bases contendo a região hipervariável do segmento codificador da subunidade S1 da proteína $\mathrm{S}$ do coronavírus bovino, conforme protocolo descrito por Brandão et al. (2003), com o objetivo de se produzirem amplicons a serem submetidos a seqüenciamento de DNA para estudos genealógicos das amostras de BCoV detectadas.

Para tanto, utilizaram-se $5 \mu \mathrm{L}$ do cDNA obtido da RT realizada utilizando-se primers randômicos (item 3.5, Pesquisa de BCoV), que foram adicionados ao mix de PCR contendo: $1 \times$ PCR Buffer ${ }^{\mathrm{TM}}$ (Invitrogen $^{\mathrm{TM}}$ ), 0,2mM de cada dNTP, 0,5 $\mu \mathrm{M}$ de cada primer (S1HS e S1HA, Quadro 6), 1,5mM MgCl $2,25,25 \mu \mathrm{L}$ água DEPC e 1,25U de Taq platinum DNA polimerase (Invitrogen ${ }^{\mathrm{TM}}$ ), para um volume final de $50 \mu \mathrm{L}$. A solução final foi submetida a 35 ciclos de $94^{\circ} \mathrm{C} / 1 \mathrm{~min}, 53,4^{\circ} \mathrm{C} / 1,5 \mathrm{~min}$ e $72^{\circ} \mathrm{C} / 1^{\prime}$ e $72^{\circ} \mathrm{C} / 10$ min para a extensão final. 
A segunda amplificação ou nested PCR foi realizada adicionando-se $5 \mu \mathrm{L}$ do produto da primeira amplificação (PCR) ao mix de nested PCR: 1 x PCR Buffer (Invitrogen $^{\mathrm{TM}}$ ), $\quad 0,2 \mathrm{mM}$ de cada dNTP, $0,5 \mu \mathrm{M}$ de cada primer, S1NS e S1NA (Quadro 6), 1,5mM $\mathrm{MgCl}_{2}, 25,25 \mu \mathrm{L}$ de água DEPC e 1,25U de Taq platinum DNA polimerase (Invitrogen ${ }^{\mathrm{TM}}$ ), para uma reação final de $50 \mu \mathrm{L}$. A solução final foi submetida a 25 ciclos de $94^{\circ} \mathrm{C} / 1 \mathrm{~min}, 58,4^{\circ} \mathrm{C} / 1,5$ min e $72^{\circ} \mathrm{C} / 1$ min para extensão de DNA e $72^{\circ} \mathrm{C} / 10$ min para extensão final.

Nessa reação também se utilizou a amostra Kakegawa como controle positivo e água DEPC como negativo.

\begin{tabular}{|c|c|c|}
\hline Primer & Seqüência (5' - 3') & $\begin{array}{c}\text { Amplicon } \\
(\mathbf{p b})\end{array}$ \\
\cline { 1 - 2 } S1HA & CTATACCCAATGGTAGGA & \multirow{2}{*}{885} \\
\cline { 1 - 2 } S1HS & CTGAAACACGACCGCTAT & \\
\hline S1NA & GTTTCTGTTAGCAGGTTTAA & \multirow{2}{*}{488} \\
\hline S1NS & ATATTACACCTATCCCCTTG & \\
\hline
\end{tabular}

Quadro 6 - Primers utilizados para detecção do gene codificador da proteína S dos BCoV, com os respectivos tamanhos de fragmentos amplificados

Dez microlitros do produto de nested foram analisados por eletroforese em gel de agarose a $1,5 \%$ corado com brometo de etídeo a $0,5 \mu \mathrm{g} / \mathrm{mL}$ e observado sob luz ultravioleta. Foram consideradas positivas as amostras que apresentaram a banda de $488 \mathrm{pb}$.

\subsection{PESQUISA DE ROTAVIRUS (RV-A) DO GRUPO A}

Para a pesquisa de rotavírus (RV-A) do grupo A, utilizou-se o kit de ELISA duplo-sanduíche KERI para diagnóstico direto (CORNAGLIA et al., 1989), produzido pelo INTA (Instituto Nacional de Tecnologia, Argentina), gentilmente cedido ela pesquisadora Daniela Rodriguez (INTA Castellar, Argentina). 


\subsubsection{Controles positivos e negativos}

Para calibração da leitura das placas pelo espectofotômetro, utilizou-se PBS/Tween como branco. Como controle positivo utilizou-se rotavírus, amostra RVA 8209 (RODRIGUEZ et al., 2004), produzido em cultivo de células MA-104, com título de $10^{1,66} \mathrm{TCID}_{50 \%} / 200 \mu \mathrm{L}$, diluída a 1:10 em água-DEPC. Como controle negativo utilizou-se suspensão fecal diluída a 30\% em água DEPC, obtidas de amostras negativas para a presença de rotavírus segundo RT-PCR para o gene codificador da RNA polimerase viral/ VP1 (Asano, 2009), utilizando-se um controle negativo, em duplicata, para cada placa.

3.7.1.1 Sensibilização das placas, anticorpos primário, secundário e conjugado

Para a realização dos ensaios, foram utilizadas placas para ELISA (NUNC $\left.{ }^{\circledR}\right)$ com 96 poços de fundo chato.

Os poços destinados à captura positiva dos RV-A, foram sensibilizados com $100 \mu \mathrm{L}$ de soro hiperimune de cobaio imunizado com Rotavírus Bovino do Grupo A (amostra NCDV-Lincoln) diluída em tampão carbonato-bicarbonato 0,05M pH9,6, para uma razão final de 1:7000.

Os poços destinados à captura negativa foram sensibilizados com $100 \mu \mathrm{L}$ soro de cobaio não imunizado, diluído da mesma forma anteriormente descrita. As placas, já contendo os soros de captura positiva e negativa foram incubadas a $4^{\circ} \mathrm{C}$, em câmara úmida, overnight.

Como anticorpo secundário, utilizou-se soro hiperimune de bovino desafiado com a amostra de RV-A mencionada anteriormente, diluído em PBS/Tween 20 para uma razão final de 1:6000. A reação foi revelada com anticorpo comercial anti-lgG bovina marcado com peroxidase, também diluído em PBS/Tween 20, para uma diluição final de 1:7000. 
As diluições de cada um dos anticorpos foram previamente determinadas em ensaios de padronização da técnica no LABMAS.

\subsubsection{Aplicação do ELISA às amostras fecais}

As amostras fecais foram previamente diluídas a $30 \%$ em água DEPC, homogeneizadas por 15s, com auxílio de vórtex, e clarificadas a 5.000 x g por 15 minutos a $4^{\circ} \mathrm{C}$, tomando-se o sobrenadante para a pesquisa de rotavírus.

Para a realização de todo o ensaio, utilizou-se o lavador de placas We WashDenley (Uniscience $®$ ), com o auxílio do qual se descartou o conteúdo previamente aplicado para sensibilização dos poços (conforme descrito no item anterior - 4.7.1.1) e procedeu-se a lavagem dos mesmos com PBS/Tween 2 vezes.

Em seguida, $100 \mu \mathrm{L}$ de cada amostra foram aplicados em 2 poços de captura positiva e 2 poços de captura negativa, constituindo as duplicatas para análise das mesmas. Além das amostras, cada placa recebeu controle positivo, controle negativo e PBS (como branco), todos em duplicata, conforme descrito para as amostras.

Uma vez aplicadas as amostras e os controles, as placas foram incubadas em câmara úmida, por $1 \mathrm{~h}$ a $37^{\circ} \mathrm{C}$. Após isso, retiraram-se as amostras aplicadas e procedeu-se a lavagem dos poços com PBS/Tween 4 vezes.

Depois da lavagem, foram aplicados $100 \mu \mathrm{L}$ de anticorpo secundário (preparado conforme item 4.7.1.1) em cada poço, e repetiu-se a incubação em câmara úmida, por $1 \mathrm{~h}$ a $37^{\circ} \mathrm{C}$, após a qual se sucedeu a retirada do mesmo e a lavagem dos poços com PBS/Tween, 4 vezes.

Em seguida, aplicaram-se $100 \mu \mathrm{L}$ de conjugado anti-lgG bovina marcado com peroxidase (também previamente preparado conforme item 4.7.1.1) em todos os poços, repetindo-se, novamente, a mesma incubação a $37^{\circ} \mathrm{C}$, em câmara úmida. Passada $1 \mathrm{~h}$, o conteúdo dos poços foi retirado e procedeu-se a lavagem com PBS / Tween, agora $5 x$.

Por fim, utilizou-se $\mathrm{H}_{2} \mathrm{O}_{2}$ /ABTS como substrato cromógeno, aplicando-se $100 \mu \mathrm{L}$ do mesmo em cada poço e incubando-se a placa ao abrigo da luz, por 10 
minutos à temperatura ambiente. A reação do cromógeno foi interrompida pela adição de $50 \mu \mathrm{L}$ de SDS 5\% em cada poço.

A absorbância de cada poço foi lida sob comprimento de onda de $405 \mathrm{~nm}$, utilizando-se o leitor Multiskan EX (Thermo Electron Corporation $\circledast$ ) e o programa Ascent $\AA^{\circledR}$ Software for Multiskan.

A Figura 7 ilustra o fluxograma dos procedimentos descritos.

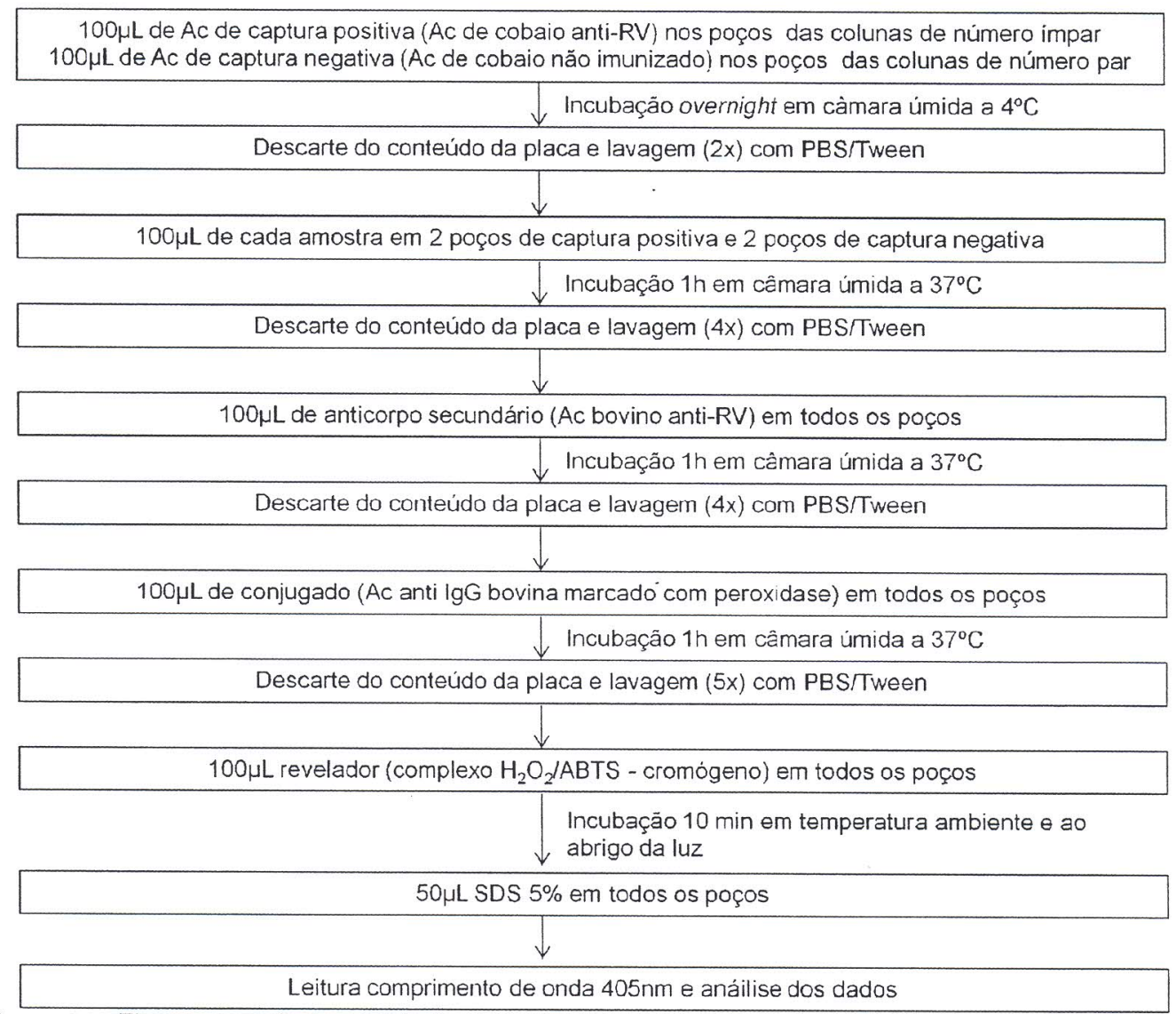

Figura 7 - Fluxograma dos procedimentos realizados para a investigação da presença de RV-A do grupo A utilizando ELISA direto duplo-sanduíche

\subsection{INTERPRETAÇÃO DOS RESULTADOS}

As planilhas contendo as absorbâncias lidas em cada poço foram copiadas para o programa Excel (Microsoft ${ }^{\circledR}$ Office). Calculou-se a densidade óptica (DO) 
corrigida de cada amostra, subtraindo-se a DO do poço de captura negativa da DO do poço de captura positiva (DO corrigida = DO captura positiva - DO captura negativa). Calculou-se, ainda, a média e o desvio padrão das DOs dos poços brancos (poços de captura positiva que receberam PBS como amostra). Por fim, calculou-se o ponto de corte para o ensaio somando-se o valor de 3 desvios padrão ao valor da média do branco (Ponto de corte $=$ Média do Branco + (3x Desvio Padrão do Branco)).

O ensaio foi considerado válido quando a DO do controle positivo foi maior que o ponto de corte e quando a média corrigida da DO do controle positivo foi maior que $0,2 \cup A$.

As amostras foram consideradas positivas quando, similarmente ao controle positivo, a DO de captura positiva foi maior que o ponto de corte do ensaio e quando a média corrigida da DO foi maior que 0,2UA. Contrariamente, as amostras foram consideradas negativas quando o valor da DO de captura positiva foi menor que 0 ponto de corte do ensaio e a DO corrigida foi menor que 0,2UA.

\subsection{ANÁLISE DOS RESULTADOS}

Com a finalidade de se determinarem os patógenos de maior importância para os casos de diarréia, a freqüência de ocorrência de cada um dos patógenos entéricos encontrados foi comparada entre as duas propriedades estudadas, pelo teste de Chi-quadrado com 1 grau de liberdade e valor de alfa de 0,05, utilizando-se o programa Minitab (Minitab Versão $14.1^{\circledR}$ 1972-2003, Minitab INC). Nos casos em que os valores das freqüências forem muito baixas, inviabilizando a aplicação de teste de Chi-quadrado, será utilizado o teste de Fisher. 
RESULTADOS 


\section{RESULTADOS}

\subsection{PROPRIEDADE COM CASOS ESPORÁDICOS DE DIARRÉIA}

Cuidando para impactar minimamente no manejo dos animais e na rotina de trabalho dos funcionários das propriedades estudadas, foi atendida a sugestão de trabalhar com 2 lotes de animais, com momentos de colheita distintos. As datas de cada uma das colheitas estão apresentadas no Quadro 7.

\begin{tabular}{|c|c|c|}
\hline Lote & Colheita & Data \\
\hline \multirow{4}{*}{ L1 } & C1 & $25 / 09 / 2008$ \\
\cline { 2 - 3 } & C2 & $26 / 11 / 2008$ \\
\cline { 2 - 3 } & C3 & $18 / 12 / 2008$ \\
\cline { 2 - 3 } & C4 & $25 / 05 / 2009$ \\
\hline \multirow{4}{*}{ L2 } & C1 & $26 / 11 / 2008$ \\
\cline { 2 - 3 } & C2 & $27 / 01 / 2009$ \\
\cline { 2 - 3 } & C3 & $24 / 02 / 2009$ \\
\cline { 2 - 3 } & C4 & $29 / 06 / 2009$ \\
\hline
\end{tabular}

Quadro 7 - Data de realização das colheitas na fazenda com casos esporádicos de diarréia dos lotes 1 (L1) e 2 (L2)

\subsubsection{Primeira colheita (c1)}

Em setembro (L1) e novembro (L2) de 2008, realizou-se a primeira colheita de amostras na fazenda com casos esporádicos de diarréia, foram colhidas amostras de 29 animais, sendo o $30^{\circ}$ incluído a partir da segunda colheita. A média de idade dos animais foi de 4 dias e nenhum dos animais apresentou diarréia. 


\subsubsection{Exame virológico}

A amostra de 1 animal foi positiva à nested-RT-PCR para detecção de BCoV $(3,44 \%)$ e 3 amostras apresentaram-se positivas no ELISA para detecção de RV-A do grupo $A(10,34 \%)$.

\subsubsection{Exame coproparasitológico}

Não se detectaram parasitas em nenhuma das amostras por nenhuma das duas técnicas realizadas.

\subsubsection{Exame bacteriológico}

Ao exame bacteriológico, dos 29 swabs semeados, obtiveram-se 33 colônias isoladas. Dessas 29 amostras, 23 (79,31\%) resultaram em isolamento de E. coli em cultura pura, isto é, sem o co-isolamento de outras espécies de bactérias; 2 (6,9\%) resultaram em isolamento de Klebsiella pneumoniae subesp. azanae, também em cultura pura; e quatro $(13,79 \%)$ resultaram em co-isolamento de duas espécies de enterobactérias: E. coli e Klebsiella oxytoca, E. coli e Klebsiella pneumoniae subesp. azanae, E. coli e Aeromonas hydrophila e, finalmente, E. coli e uma colônia bacteriana que não apresentou perfil de fermentação que permitisse caracterização pelo método utilizado no presente estudo e, por essa razão, foi chamada de "Não fermentadora". Os resultados do exame bacteriológico estão apresentados na Tabela 1. 
Tabela 1 - Espécies de bactérias isoladas de swabs retais de bezerros de corte na primeira colheita realizada na fazenda com casos esporádicos de diarréia. São Paulo, 2008

\begin{tabular}{lc}
\hline Bactéria & $\%$ \\
\hline E. coli & $79,31 \%$ \\
Klebsiella pneumoniae subesp. azanae & $6,90 \%$ \\
E. coli + 1 espécie de enterobactéria & $10,34 \%$ \\
E. coli + Não fermentadora & $3,45 \%$ \\
\hline Total & $\mathbf{1 0 0 , 0 0 \%}$ \\
\hline
\end{tabular}

4.1.1.3.1 Detecção de fatores de virulência de E. coli

Não se detectou a presença de nenhum dos genes codificadores dos fatores de virulência investigados pela Multiplex-PCR utilizada no presente estudo, em nenhuma das 27 colônias de E. coli isoladas.

\subsubsection{Segunda colheita (c2)}

$\mathrm{Na}$ segunda colheita de amostras na fazenda com casos esporádicos de diarréia, realizada em novembro (L1) de 2008 e janeiro de 2009 (L2), colheram-se amostras dos 30 animais que totalizaram o grupo experimental, e a idade média nos mesmos, nessa ocasião, foi de 63 dias. No momento da colheita, 2 animais apresentavam diarréia. 


\subsubsection{Exame virológico}

Dentre as amostras obtidas nessa segunda colheita, 2 (6,66\%) foram positivas à nested-RT-PCR para detecção de BCoV, e 1 (3,33\%) foi positiva para RV-A.

\subsubsection{Exame coproparasitológico}

No exame coproparasitológico, 3 (10\%) amostras apresentaram resultado negativo. Encontraram-se oocistos de Eimeria spp em 27 das amostras, em diferentes quantidades: raros $(22-73,33 \%), 1+(4-13,33 \%)$ e $4+(1-3,33 \%)$. Encontraram-se, ainda, raros ovos de helmintos da superfamília Strongyloidea em 5 amostras (16,66\%). Os dados descritos estão apresentados na Tabela 2.

Tabela 2 - Parasitas identificados por exame coproparasitológico em amostras fecais de bezerros de corte na segunda colheita realizada na fazenda com casos esporádicos de diarréia. São Paulo, 2008-2009

\begin{tabular}{lcc}
\hline & Coproparasitológico Final & \\
\hline Parasita & Quant. & $\%$ \\
\hline Negativo & 0 & $10,00 \%$ \\
Eimeria spp & raros & $73,33 \%$ \\
Eimeria spp & + & $13,33 \%$ \\
Eimeria spp & ++++ & $3,33 \%$ \\
Strongyloidea & raros & $16,67 \%$ \\
\hline
\end{tabular}

As técnicas de centrífugo-sedimentação em água-éter (método de Ritchie) e centrífugo-flutuação em solução supersaturada de sacarose (método de Sheater) apresentaram divergências na detecção do parasitas em 12 (40\%) das amostras investigadas. 
O método de Sheater apresentou maior sensibilidade na detecção de oocistos de Eimeria spp em 10 amostras, identificando o parasita em amostras diagnosticas negativas para o mesmo pelo método de Ritchie (5 amostras) e identificando-o em maior quantidade (5 amostras).

As técnicas divergiram, também, na identificação de ovos de Strongyloidea em 4 amostras, sendo que 2 delas apresentaram resultado negativo pelo método de Ritchie e resultado positivo (com detecção de raros ovos desses helmintos) pelo método de Sheater, e vice versa. Os resultados referentes a cada uma das técnicas estão apresentados na Tabela 3.

Tabela 3 - Parasitas identificados por exame coproparasitológico em amostras fecais de bezerros de corte na segunda colheita realizada na fazenda com casos esporádicos de diarréia, pela técnica de centrífugo-flutuação em solução supersaturada de sacarose (método de Sheater modificado) e de centrífugo-sedimentação em água-éter (método de Ritchie). São Paulo, 2008-2009

\begin{tabular}{|c|c|c|c|c|c|}
\hline \multicolumn{6}{|c|}{ Resultados obtidos pelos diferentes métodos } \\
\hline \multicolumn{3}{|c|}{ Água-Éter } & \multicolumn{3}{|c|}{ Sacarose } \\
\hline Parasita & Quant. & $\%$ & Parasita & Quant. & $\%$ \\
\hline Negativo & 0 & $26,67 \%$ & Negativo & 0 & $10,00 \%$ \\
\hline Eimeria spp & raros & $73,33 \%$ & Eimeria spp & raros & $73,33 \%$ \\
\hline Eimeria spp & + & $0,00 \%$ & Eimeria spp & + & $13,33 \%$ \\
\hline Eimeria spp & ++++ & $0,00 \%$ & Eimeria spp & ++++ & $3,33 \%$ \\
\hline Strongyloidea & raros & $10,00 \%$ & Strongyloidea & raros & $16,67 \%$ \\
\hline
\end{tabular}

\subsubsection{Exame bacteriológico}

Dos 30 swabs colhidos, isolaram-se 38 colônias de bactérias distintas. Em 23 $(73,33 \%)$ das amostras, isolou-se exclusivamente Escherichia coli; em 2 amostras foram isoladas $E$. coli e uma colônia de bactéria Não Fermentadora, e em 6 amostras (20\%) isolaram-se E. coli e mais uma das seguintes enterobactérias: Klebsiella pneumoniae subesp. Azanae, Edwarsiella tara biogrupo I e Hafnia alvei.

Os resultados descritos nesse item estão apresentados na Tabela 4. 
Tabela 4 - Espécies de bactérias isoladas de swabs retais de bezerros de corte na segunda colheita realizada na fazenda com casos esporádicos de diarréia. São Paulo, 2008-2009

\begin{tabular}{lc}
\hline Bactéria & $\%$ \\
\hline E. coli & $73,33 \%$ \\
E. coli + 1 espécie de enterobactéria & $20,00 \%$ \\
E. coli + Não Fermentadora & $6,67 \%$ \\
\hline Total & $\mathbf{1 0 0 , 0 0 \%}$ \\
\hline
\end{tabular}

\subsection{Detecção de fatores de virulência de E. coli}

Detectou-se a presença do gene codificador da toxina Shiga-like do tipo 1 (Stx1) em 1 amostra (3,33\%), do gene codificador de intimina (eae) em 2 (6,66\%) amostras e do gene codificador da adesina K99 em 3 amostras (10\%).

Vale ressaltar que foram detectados simultaneamente os genes codificadores de eae e K99 em uma mesma colônia de E. coli. Vale destacar, ainda, que foram isoladas 2 colônias de $E$. coli geneticamente distintas de um único swab, uma contendo o gene codificador da eae e outra contendo o gene codificador de K99.

Não foi detectada a presença de genes codificadores de fatores de virulência em $26(83,87 \%)$ das 31 colônias de $E$. coli isoladas no total.

\subsubsection{Terceira colheita (c3)}

Em dezembro de 2008 (L1) e fevereiro de 2009 (L2), foram colhidas amostras fecais dos mesmos 30 animais amostrados na colheita anterior. Nessa ocasião, nenhum deles apresentava diarréia e a média de idade dos mesmos era de 89 dias. 


\subsubsection{Exame virológico}

Não foi detectada a presença de BCoV em nenhuma das amostras obtidas nessa colheita.

Foi detectada a presença de RV-A em uma das amostras.

\subsubsection{Exame coproparasitológico}

Não foram detectados parasitas em 5 (16,57\%) das 30 amostras obtidas nessa terceira colheita. Detectaram-se a presença de raros oocistos de Eimeria spp em 25 (83,33\%) amostras e de, também, raros ovos de Strongyloidea em 6 (20\%) amostras. Os resultados finais referentes a essa colheita estão apresentados na Tabela 5.

Tabela 5 - Parasitas identificados por exame coproparasitológico em amostras fecais de bezerros de corte na terceira colheita realizada na fazenda com casos esporádicos de diarréia. São Paulo, 2008-2009

\section{Coproparasitológico Final}

\begin{tabular}{lcc}
\hline Parasita & Quant. & $\%$ \\
\hline Negativo & 0 & $10,00 \%$ \\
Eimeria spp & Raros & $83,33 \%$ \\
Strongyloidea & Raros & $20,00 \%$ \\
\hline
\end{tabular}

Assim como observado no exame das amostras da colheita 2, verificou-se a divergência de resultados, entre os dois métodos empregados, em 12 (40\%) das amostras investigadas.

Novamente, o método de Sheater apresentou maior sensibilidade na detecção de oocistos de Eimeria spp, identificando o coccídio em 7 amostras que haviam sido diagnosticas negativas para o mesmo pelo método de Ritchie. Em 1 das 
amostras, o método de Sheater também foi mais sensível na detecção de raros ovos de Strongyloidea que não foram detectados pelo método de Ritchie.

Contrariamente, o método de centrífugo-sedimentação em água-éter apresentou maior sensibilidade na deteação de Strongyloidea, detectando raros ovos dessa família de helmintos em 3 amostras nas quais o método de Sheater não os havia identificado. Os dados referentes a cada uma das técnicas estão apresentados da Tabela 6.

Tabela 6 - Parasitas identificados por exame coproparasitológico em amostras fecais de bezerros de corte na terceira colheita realizada na fazenda com casos esporádicos de diarréia, pela técnica de centrífugoflutuação em solução supersaturada de sacarose (método de Sheater modificado) e de centrífugo-sedimentação em água-éter (método de Ritchie). São Paulo, 2008-2009

\begin{tabular}{lccllcr}
\hline \multicolumn{5}{c}{ Resultados obtidos pelos diferentes métodos } \\
\hline & Água-Éter & & & \multicolumn{3}{c}{ Sacarose } \\
\cline { 1 - 2 } Parasita & Quant. & $\%$ & & Parasita & Quant. & $\%$ \\
Negativo & 0 & $40,00 \%$ & & Negativo & 0 & $20,00 \%$ \\
Eimeria spp & raros & $60,00 \%$ & & Eimeria spp & raros & $80,00 \%$ \\
Strongyloidea & raros & $16,67 \%$ & & Strongyloidea & raros & $6,67 \%$ \\
\hline
\end{tabular}

\subsubsection{Exame bacteriológico}

A partir dos 30 swabs colhidos, isolaram-se 42 colônias de bactérias distintas, das quais 29 foram E. colis. Em 18 (60\%) amostras, foi isolada E. coli em cultura pura. Também em cultura pura, swabs isolou-se Salmonella spp em 1 (3,33\%) das amostras examinadas. Em uma das amostras isolou-se E. coli em co-infecção com uma bactéria Não fermentadora. Nos demais swabs obteve-se o coi-isolamento de E. coli com outras espécies de enterobactérias bactérias: Klebsiella oxytoca, Klebsiella pneumoniae, Klebsiella pneumoniae subesp. azanae, Shigella spp, Edwarsiella tarda biogrupo I, Citrobacter diversus e Citrobacter freudii.

Os referidos resultados estão apresentados da Tabela 7. 
Tabela 7 - Espécies de bactérias isoladas de swabs retais de bezerros de corte na terceira colheita realizada na fazenda com casos esporádicos de diarréia. São Paulo, 2008-2009

\begin{tabular}{lc}
\hline Bactéria & $\%$ \\
\hline E. coli & $60,00 \%$ \\
Salmonella spp & $3,33 \%$ \\
E. coli + Não fermentadora & $3,33 \%$ \\
E. coli + 1 espécie de enterobactéria & $30,00 \%$ \\
E. coli + 2 espécies de enterobactérias & $3,33 \%$ \\
\hline Total & $\mathbf{1 0 0 , 0 0 \%}$ \\
\hline
\end{tabular}

\subsection{Detecção de fatores de virulência de E. coli}

Dentre as amostras examinadas, 4 (13,33\%) apresentaram-se positivas para o gene codificador da Stx1 e 3 para o gene codificador da eae. Em amos os casos, 2 das amostras positivas provieram de $E$. coli isolada em cultura pura.

Em $24(82,76 \%)$ das 29 E. coli isoladas, não foi verificada a presença de nenhum dos fatores de virulência investigados pela Multiplex-PCR empregada nesse trabalho.

\subsubsection{Quarta colheita (C4)}

A quarta colheita da fazenda com casos esporádicos de diarréia foi realizada em maio de 2009 (L1) e em junho de 2009 (L2), na ocasião da desmama dos mesmos. A idade média dos animais era de 239 dias e nenhum deles apresentou diarréia ao momento da colheita. 


\subsubsection{Exame virológico}

Nessa colheita, não detectou-se nem a presença de BcoV, nem a presença de RV-A do grupo A.

\subsubsection{Exame coproparasitológico}

Em $11(36,57 \%)$ das amostras colhidas não foi detectada a presença de parasitas. Detectaram-se raros oocistos de Eimeria spp em 18 (60\%) amostras, e raros ovos de helmintos da família Strongyloidea em 2 (6,66\%) das 30 amostras colhidas. Os resultados finais do exame coproparasitológico referente à quarta colheita de amostras está apresentado na Tabela 8.

Tabela 8 - Parasitas identificados por exame coproparasitológico em amostras fecais de bezerros de corte na quarta colheita realizada na fazenda com casos esporádicos de diarréia. São Paulo, 2009

\section{Coproparasitológico Final}

\begin{tabular}{lcc}
\hline Parasita & Quant. & $\%$ \\
\hline Negativo & 0 & $36,67 \%$ \\
Eimeria spp & Raros & $60,00 \%$ \\
Strongyloidea & Raros & $6,67 \%$ \\
\hline
\end{tabular}

Verificaram-se diferenças nos resultados obtidos pelas duas técnicas diagnósticas utilizadas em $14(46,67 \%)$ das amostras examinadas. Em apenas 1 amostra o método de Ritchie apresentou maior sensibilidade, detectando raros ovos de Strongyloidea, enquanto essa mesma amostra foi diagnosticada negativa pelo método de Sheater. Em contrapartida, a técnica de centrífugo-flutuação em solução supersaturada de sacarose foi mais sensível na detecção tanto de oocistos de Eimeria spp quanto de ovos de Strongyloidea, em 13 e 2 amostras, respectivamente, que foram diagnosticadas negativas pelo método de Ritchie. 
A Tabela 9 resume os resultados obtidos pelas duas técnicas referidas.

Tabela 9 - Parasitas identificados por exame coproparasitológico em amostras fecais de bezerros de corte na quarta colheita realizada na fazenda com casos esporádicos de diarréia, pela técnica de centrífugo-flutuação em solução supersaturada de sacarose (método de Sheater modificado) e de centrífugo-sedimentação em água-éter (método de Ritchie). São Paulo, 2009

\begin{tabular}{|c|c|c|c|c|c|}
\hline \multicolumn{6}{|c|}{ Resultados obtidos pelos diferentes métodos } \\
\hline \multicolumn{3}{|c|}{ Água-Éter } & \multicolumn{3}{|c|}{ Sacarose } \\
\hline Parasita & Quant. & $\%$ & Parasita & Quant. & $\%$ \\
\hline Negativo & 0 & $80,00 \%$ & Negativo & 0 & $40,00 \%$ \\
\hline Eimeria spp & raros & $16,67 \%$ & Eimeria spp & raros & $60,00 \%$ \\
\hline Strongyloidea & raros & $3,33 \%$ & Strongyloidea & raros & $6,67 \%$ \\
\hline
\end{tabular}

\subsubsection{Exame bacteriológico}

Foram isoladas 49 colônias de bactérias distintas, pelo cultivo dos 30 swabs colhidos. Em 27(90\%) amostras foi detectada a presença de E. coli, sendo que em $12(40 \%)$ as E. coli apresentaram-se em cultura pura. Também ocorreu isolamento em cultura pura de Klebsiella pneumoniae subesp. azanae em 2 (6,67\%) swabs. Conforme apresentado na Tabela 10, nas demais amostras verificou-se o coisolamento de E. coli com outras enterobactérias: Citrobacter amalonaticus, Citrobacter diversus, Citrobacter freudii, Edwarsiella hoshinae, Enterobacter spp, Klebsiella pneumoniae azanae, Salmonella spp e Shigella spp. 
Tabela 10 - Espécies de bactérias isoladas de swabs retais de bezerros de corte na quarta colheita realizada na fazenda com casos esporádicos de diarréia. São Paulo, 2009

\begin{tabular}{lc}
\hline Bactéria & $\%$ \\
\hline E. coli & $40,00 \%$ \\
Klebsiella pneumoniae subesp. azanae & $6,67 \%$ \\
E. coli + 1 espécie de enterobactéria & $43,33 \%$ \\
E. coli +2 espécies de enterobactérias & $10,00 \%$ \\
\hline Total & $\mathbf{1 0 0 , 0 0 \%}$ \\
\hline
\end{tabular}

4.1.4.3.1 Detecção de fatores de virulência de E. coli

Detectou-se a presença do gene codificador da Stx1 em 1 (3,33\%) amostra e da eae em outra, pela Multiplex-PCR utilizada nesse trabalho. Tendo sido o gene codificador da eae detectado em uma amostra na qual isolou-se exclusivamente $E$. coli.

Não foi detectada a presença de fatores de virulência em $26(96,3 \%)$ das 27 colônias de E. coli isoladas das amostras da quarta colheita.

\subsection{PROPRIEDADE COM CASOS RECORRENTES DE DIARRÉIA}

Em acordo com a disponibilidade de animais e mantendo a sistemática de trabalho utilizada na fazenda com casos esporádicos de diarréia, formaram-se 2 lotes de animais para a realização das colheitas. As datas em que as colheitas foram realizadas estão apresentadas no Quadro 8. 


\begin{tabular}{|c|c|c|}
\hline Lote & Colheita & Data \\
\hline \multirow{4}{*}{ L1 } & C1 & $15 / 09 / 2009$ \\
\cline { 2 - 3 } & C2 & $24 / 11 / 2009$ \\
\cline { 2 - 3 } & C3 & $19 / 01 / 2010$ \\
\cline { 2 - 3 } & C4 & $11 / 02 / 2010$ \\
\hline \multirow{4}{*}{ L2 } & C1 & $24 / 11 / 2009$ \\
\cline { 2 - 3 } & C2 & $06 / 01 / 2010$ \\
\cline { 2 - 3 } & C3 & $29 / 01 / 2010$ \\
\cline { 2 - 3 } & C4 & $02 / 03 / 2010$ \\
\hline
\end{tabular}

Quadro 8 - Datas de realização das colheitas na fazenda com casos recorrentes de diarréia dos lotes 1 (L1) e 2 (L2)

\subsubsection{Primeira colheita (C1)}

Em setembro (L1) e novembro (L2) de 2009, realizou-se a primeira colheita de amostras na fazenda com casos esporádicos de diarréia, foram colhidas amostras de 31 animais. A média de idade dos animais incluídos no grupo experimental foi de 29 dias e 7 (22.6\%) dos animais apresentava diarréia no momento da colheita.

\subsubsection{Exame virológico}

A amostra de 1 animal foi positiva à nested-RT-PCR para detecção de BCoV $(3,22 \%)$ e 3 amostras apresentaram-se positivas no ELISA para detecção de RV-A do grupo $A(9,7 \%)$. 


\subsubsection{Exame coproparasitológico}

Dentre as 31 amostras dessa colheita, 12 (38,71\%) foram negativas ao exame coproparasitológico e 7 (22,58\%) apresentaram raros ovos de helmintos da super família Strongyloidea. Detectaram-se raros oocistos de Eimeria spp em 19 $(61,29 \%)$ das amostras, e uma cruz desse mesmo coccídeo em 1 (3,23\%) das amostras. Os resultados dos exames coproparasitológicos estão apresentados na Tabela 11.

Tabela 11 - Parasitas identificados por exame coproparasitológico em amostras fecais de bezerros de corte na primeira colheita realizada na fazenda com casos recorrentes de diarréia. São Paulo, 2009

\begin{tabular}{lccc}
\hline \multicolumn{3}{c}{ Coproparasitológico Final } \\
\hline Parasita & Quant. & $\%$ \\
\hline Negativo & 0 & $38,71 \%$ \\
Eimeria spp & raros & $61,29 \%$ \\
Eimeria spp & + & $3,23 \%$ \\
Strongyloidea & raros & $22,58 \%$ \\
\hline
\end{tabular}

Assim como observado no exame coproparasitológico das amostras provenientes da propriedade com casos esporádicos de diarréia, houve divergência entre a sensibilidade das técnicas empregadas no exame de 10 (32,25\%).

A técnica de centrífugo-flutuação em solução supersaturada de sacarose foi mais sensível na detecção de oocistos de Eimeria spp em 3 amostras que foram diagnosticadas negativas pelo método de Ritchie. Adicionalmente, em 1 outra amostra na qual haviam-se detectado raros oocistos desse cocídio pela centrífugosedimentação em água-éter, o método de Sheater detectou a presença de 1 cruz do parasita. O mesmo ocorreu na detecção de ovos de Strongyloidea em 2 amostras das amostras examinadas, nas quais o método de Ritchie não permitiu a detecção de parasitas, mas o método do Sheaterpermitiu a detecção da presença de raros ovos dessa família de parasitas. 
Entretanto a centrífugo-sedimentação em água-éter apresentou sensibilidade superior na detecção de raros ovos de Strongyloidea em 6 amostras, diagnosticadas negativas pela centrífugo-flutuação em solução supersaturada de sacarose.

Os resultados referentes a cada uma das técnicas diagnóticas estão resumidos na Tabela 12.

Tabela 12 - Parasitas identificados por exame coproparasitológico em amostras fecais de bezerros de corte na primeira colheita realizada na fazenda com casos recorrentes de diarréia, pela técnica de centrífugoflutuação em solução supersaturada de sacarose (método de Sheater modificado) e de centrífugo-sedimentação em água-éter (método de Ritchie). São Paulo, 2009

Resultados obtidos pelos diferentes métodos

\begin{tabular}{lcclcc}
\hline & Água-Éter & & & Sacarose \\
\hline Parasita & Quant. & $\%$ & Parasita & Quant. & $\%$ \\
Negativo & 0 & $45,16 \%$ & Negativo & 0 & $45,16 \%$ \\
Eimeria spp & raros & $51,61 \%$ & Eimeria spp & raros & $54,84 \%$ \\
Eimeria spp & + & $0,00 \%$ & Eimeria spp & + & $3,23 \%$ \\
Strongyloidea & raros & $19,35 \%$ & Strongyloidea & raros & $6,45 \%$ \\
\hline
\end{tabular}

\subsubsection{Exame bacteriológico}

Dos 31 swabs examinados, foram isoladas 33 colônias de E. coli, sendo tendo sido $20(64,52 \%)$ delas isoladas em cultura pura. As demais 11 amostras demonstraram o co-isolamento de E. coli juntamente com outras espécies de enterobactérias, conforme apresentado na Tabela 13. Dentre as espécies de enterobactérias co-isoladas detectaram-se: Aeromonas hydrophila, Citrobacter amalonaticus, Citrobacter diversus, Citrobacter freudii, Edwarsiella hoshinae, Edwarsiella tarda biogrupo I, Klebsiella oxytoca, Klebsiella pneumoniae subesp. azanae, Providencia spp e Serratia spp. 
Tabela 13 - Espécies de bactérias isoladas de swabs retais de bezerros de corte na primeira colheita realizada na fazenda com casos recorrentes de diarréia. São Paulo, 2009

\begin{tabular}{lc}
\hline Bactéria & $\%$ \\
\hline E. coli & $64,52 \%$ \\
E. coli +1 espécie de enterobactéria & $19,35 \%$ \\
E. coli +2 espécie de enterobactéria & $12,90 \%$ \\
E. coli +3 espécie de enterobactéria & $3,23 \%$ \\
\hline Total & $\mathbf{1 0 0 , 0 0 \%}$ \\
\hline
\end{tabular}

4.2.1.3.1 Detecção de fatores de virulência de E. coli

Foi detectada a presença dos genes codificadores dos fatores de virulência Stx1 e Stx2 em $4(12,9 \%)$ das amostras colhidas, pela Multiplex-PCR utilizada no presente estudo. Quanto ao gene da Stx1, 2 das amostras positivas eram culturas puras de E. coli, e quanto ao gene da Stx2, 3.

Essa mesma técnica permitiu, ainda, a detecção do gene codificador da eae em 2 (6,45\%) das amostras investigadas.

Em $23(69,7 \%)$ das 33 colônias de E. coli isoladas, não foi detectada a presença de genes codificadores de fatres de virulência.

\subsubsection{Segunda colheita (C2)}

$\mathrm{Na}$ segunda colheita de amostras na fazenda com casos recorrentes de diarréia, realizada em novembro (L1) de 2009 e janeiro de 2010 (L2), colheram-se amostras dos mesmos 31 animais amostrados na primeira colheita, e a idade média nos mesmos, nessa ocasião, foi de 84 dias. No momento da colheita, 3 (9,67\%) animais apresentavam diarréia. Entre as colheitas 2 animais apresentaram diarréia, mas não foram colhidas amostras nas respectivas ocasiões. 


\subsubsection{Exame virológico}

Dentre as amostras obtidas na segunda colheita, $2(6,45 \%)$ foram positivas para RV-A, e não se detectou a presença de BCoV pela nested-RT-PCR.

\subsubsection{Exame coproparasitológico}

No exame coproparasitológico, 1 (3,23\%) amostra foi negativa. Encontraramse raros oocistos de Eimeria spp em 30 das amostras, em diferentes quantidades: raros $(26-83,87 \%), 2$ cruzes $(2-6,45 \%)$ e 3 cruzes $(2-6,45 \%)$. Encontraram-se, ainda, raros ovos de helmintos da superfamília Strongyloidea em 12 amostras (38,71\%) e do gênero Trichuris spp em 6 amostras (19,35\%). Os dados descritos estão apresentados na Tabela 14.

Tabela 14 - Parasitas identificados por exame coproparasitológico em amostras fecais de bezerros de corte na segunda colheita realizada na fazenda com casos recorrentes de diarréia. São Paulo, 2009

\begin{tabular}{|c|c|c|}
\hline \multicolumn{3}{|c|}{ Coproparasitológico Final } \\
\hline Parasita & Quant. & $\%$ \\
\hline Negativo & 0 & $3,23 \%$ \\
\hline Eimeria spp & Raros & $83,87 \%$ \\
\hline Eimeria spp & ++ & $6,45 \%$ \\
\hline Eimeria spp & +++ & $6,45 \%$ \\
\hline Strongyloidea & Raros & $38,71 \%$ \\
\hline Trichuris spp & Raros & $19,35 \%$ \\
\hline
\end{tabular}

Assim como relatado nos resultados obtidos em colheitas anteriores, houve divergência de resultados, entre as duas técnicas empregadas, em 13 (41,9\%) amostras. 
O método de Sheater foi mais sensível na detecção e quantificação de oocistos de Eimerias spp em 5 amostras. O mesmo ocorreu na detecção de ovos de Strongyloidea (3 amostras) e Trichuris spp (2 amostras), em amostras diagnosticadas negativas para esses parasitas pelo método de Ritchie.

O método de centrífugo-sedimentação em água-éter, por sua vez, apresentou sensibilidade superior na detecção de raros ovos de helmintos da super família Strongyloidea (3 amostras) e do gênero Trichuris spp (3 amostras), em amostras nas quais esses parasitas não foram identificados pelo método de centrífugo-flutuação em solução supersaturada de sacarose.

O resumo comparativo dos resultados apresentados conta na Tabela 15.

Tabela 15 - Parasitas identificados por exame coproparasitológico em amostras fecais de bezerros de corte na segunda colheita realizada na fazenda com casos recorrentes de diarréia, pela técnica de centrífugoflutuação em solução supersaturada de sacarose (método de Sheater modificado) e de centrífugo-sedimentação em água-éter (método de Ritchie). São Paulo, 2009

\begin{tabular}{|c|c|c|c|c|c|}
\hline \multicolumn{6}{|c|}{ Resultados obtidos pelos diferentes métodos } \\
\hline \multicolumn{3}{|c|}{ Água-Éter } & \multicolumn{3}{|c|}{ Sacarose } \\
\hline Parasita & Quant. & $\%$ & Parasita & Quant. & $\%$ \\
\hline Negativo & 0 & $6,45 \%$ & Negativo & 0 & $6,45 \%$ \\
\hline Eimeria spp & raros & $87,10 \%$ & Eimeria spp & raros & $80,65 \%$ \\
\hline Eimeria spp & ++ & $3,23 \%$ & Eimeria spp & ++ & $6,45 \%$ \\
\hline Eimeria spp & +++ & $0,00 \%$ & Eimeria spp & +++ & $6,45 \%$ \\
\hline Strongyloidea & raros & $32,26 \%$ & Strongyloidea & raros & $29,03 \%$ \\
\hline Trichuris spp & raros & $12,90 \%$ & Trichuris spp & raros & $9,68 \%$ \\
\hline
\end{tabular}

\subsubsection{Exame bacteriológico}

Isolaram-se 70 colônias distintas, a partir dos 31 swabs colhidos, dentre as quais 26 eram E. coli, resultando em $83,87 \%$ de isolamento dessa espécie de bactéria nas amostras investigadas. Entretanto, nessas amostras, obteve-se 0 isolamento de $E$. coli em cultura pura em apenas $2(6,45 \%)$ das amostras. Isolou-se, também em cultura pura, Serratia spp em 1 (3,23\%) amostra. 
Verificou-se o co-isolamento de E. coli e outras espécies de enterobactérias em $24(77,41 \%)$ das amostras examinadas. As enterobactérias detectadas incluem: Aeromonas hydrophila, Citrobacter amalonaticus, Citrobacter diversus, Edwarsiella hoshinae, Edwarsiella tarda biogrupo I, Enterobacter spp, Klebsiella oxytoca, Klebsiella pneumoniae subesp. azanae, Klebsiella pneumoniae subesp. pneumoniae, Salmonella spp e Serratia spp.

Além disso, foram co-isoladas enterobactérias sem que houvesse 0 isolamento conjunto de E. coli em 4 (12,9\%) amostras. Os resultados completos estão apresentados na Tabela 16.

Tabela 16 - Espécies de bactérias isoladas de swabs retais de bezerros de corte na segunda colheita realizada na fazenda com casos recorrentes de diarréia. São Paulo, 2009

\begin{tabular}{lc}
\hline Bactéria & $\%$ \\
\hline E. coli & $6,45 \%$ \\
Serratia spp & $3,23 \%$ \\
E. coli + 1 espécie de enterobactéria & $41,94 \%$ \\
E. coli + 2 espécie de enterobactéria & $32,26 \%$ \\
E. coli + 3 espécie de enterobactéria & $3,23 \%$ \\
+ de 1 espécie de enterobactéria sem a presença de E. coli & $12,90 \%$ \\
\hline Total & $\mathbf{1 0 0 , 0 0 \%}$ \\
\hline
\end{tabular}

4.2.2.3.1 Detecção de fatores de virulência de E. coli

Detectou-se a presença do gene codificador de Stx1 em 7 amostras (22,58\%), do gene codificador de Stx2 foi detectado em $5(16,12 \%)$ amostras e do gene codificador da eae em 3 amostras (9,67\%).

Não foi encontrado nenhum dos genes pesquisados em $12(46,15 \%)$ das 26 colônias de $E$. coli isoladas. 


\subsubsection{Terceira colheita (C3)}

Em janeiro de 2010, colheram-se novas amostras dos 31 animais estudados, $1(3,22 \%)$ deles apresentava diarréia no momento da colheita e a média de idade dos bezerros era de 119 dias.

\subsubsection{Exame virológico}

Não foi detectada a presença nem de BCoV nem de RV-A do grupo A nas amostras da terceira colheita realizada na propriedade com casos recorrentes de diarréia.

\subsubsection{Exame coproparasitológico}

Das 31 amostras fecais colhidas, 1 (3,23\%) foi negativa ao exame coproparasitológico. Adicionalmente, foram detectados raros oocistos de Eimeria spp (30 - 96,77\%), raros ovos de helmintos da superfamília Strongyloidea (11 $35,48 \%)$, e raros ovos de helmintos dos gêneros Strongyloides spp (2 - 6,45\%) e Trichuris spp (3-9,68\%). Os resultados estão apresentados na Tabela 17.

Tabela 17 - Parasitas identificados por exame coproparasitológico em amostras fecais de bezerros de corte na terceira colheita realizada na fazenda com casos recorrentes de diarréia. São Paulo, 2009

\begin{tabular}{lcc}
\multicolumn{4}{c}{ Com casos recorrentes de diarréia. São Paulo, 2009 } \\
\hline Parasita & Quant. & $\%$ \\
\hline Negativo & 0 & $3,23 \%$ \\
Eimeria spp & raros & $96,77 \%$ \\
Strongyloidea & raros & $35,48 \%$ \\
Trichuris & raros & $9,68 \%$ \\
Strongyloides & raros & $6,45 \%$ \\
\hline
\end{tabular}


Houve divergência nos resultados obtidos por cada uma das técnicas empregadas em $12(38,7 \%)$ amostras.

A técnica de centrífugo-sedimentação em água-éter apresentou maior sensibilidade na detecção de ovos de Strongyloidea em 4 amostras, nas quais o método de Sheater não os havia detectado. O mesmo ocorreu na detecção de ovos de Strongyloides spp e de ovos de Trichuris spp, em 2 amostras, para cada um desses gêneros de parasitas.

A técnica de centrífugo-flutuação em solução supersaturada de sacarose, por sua vez, foi mais sensível na detecção de oocistos de Eimeria spp, em 4 amostras, diagnosticadas negativas pelo método de Ritchie. O método de Sheater detectou, ainda, ovos de Strongyloidea em 3 amostras nas quais os ovos desse parasita não foi detectado pelo outro método.

Os resultados obtidos pelo emprego de cada uma das técnicas estão apresentados na Tabela 18.

Tabela 18 - Parasitas identificados por exame coproparasitológico em amostras fecais de bezerros de corte na terceira colheita realizada na fazenda com casos recorrentes de diarréia, pela técnica de centrífugo-flutuação em solução supersaturada de sacarose (método de Sheater modificado) e de centrífugosedimentação em água-éter (método de Ritchie). São Paulo, 2010

\begin{tabular}{|c|c|c|c|c|c|}
\hline \multicolumn{6}{|c|}{ Resultados obtidos pelos diferentes métodos } \\
\hline \multicolumn{3}{|c|}{ Água-Éter } & \multicolumn{3}{|c|}{ Sacarose } \\
\hline Parasita & Quant. & $\%$ & Parasita & Quant. & $\%$ \\
\hline Negativo & 0 & $16,13 \%$ & Negativo & 0 & $6,45 \%$ \\
\hline Eimeria spp & raros & $83,87 \%$ & Eimeria spp & raros & $93,55 \%$ \\
\hline Strongyloidea & raros & $25,81 \%$ & Strongyloidea & raros & $25,81 \%$ \\
\hline Trichuris & raros & $9,68 \%$ & Trichuris & raros & $3,23 \%$ \\
\hline Strongyloides & raros & $9,68 \%$ & Strongyloides & raros & $0,00 \%$ \\
\hline
\end{tabular}

\subsubsection{Exame bacteriológico}

Dos 31 swabs colhidos, foram isoladas 74 colônias de espécies distintas de bactérias. Ao total, isolaram-se 29 (93,54\%) E. coli das amostras, sendo que em apenas $1(3,23 \%)$ delas verificou-se o isolamento de $E$. coli em cultura pura. 
Verificou-se o co-isolamento de E. coli com mais 1, 2 e 3 espécies de enterobactérias em 17 (54,84\%), 10 (32,26\%) e 1 (3,23\%) amostra, respectivamente. Houve, ainda, o co-isolamento de mais de uma espécie de enterobactéria, sem o isolamento de $E$. coli, em $2(6,45 \%)$ swabs.

As enterobactérias isoladas incluem-se as seguintes espécies: Aeromonas hydrophila, Citrobacter amalonaticus, Citrobacter diversus, Citrobacter freudii, Edwarsiella hoshinae, Edwarsiella tarda biogrupo I, Enterobacter spp, Klebsiella oxytoca, Klebsiella pneumoniae subesp. azanae, Klebsiella pneumoniae subesp. pneumoniae e Serratia spp.

Os dados referentes aos isolamentos bacterianos estão apresentados na Tabela 19.

Tabela 19 - Espécies de bactérias isoladas de swabs retais de bezerros de corte na terceira colheita realizada na fazenda com casos recorrentes de diarréia. São Paulo, 2010

\begin{tabular}{lc}
\hline Bactéria & $\%$ \\
\hline E. coli & $3,23 \%$ \\
E. coli + 1 espécie de enterobactéria & $54,84 \%$ \\
E. coli + 2 espécie de enterobactéria & $32,26 \%$ \\
E. coli + 3 espécie de enterobactéria & $3,23 \%$ \\
+ de 1 espécie de enterobactéria sem a presença de E. Coli & $6,45 \%$ \\
\hline Total & $\mathbf{1 0 0 , 0 0 \%}$ \\
\hline
\end{tabular}

4.2.3.3.1 Detecção de fatores de virulência de E. coli

Foi detectada a presença do gene codificador da Stx1 em 6 (19,35\%) das amostras, sendo que 1 gene foi detectado em amostra de $E$. coli isolada em colônia pura. Os genes codificadores da toxina Stx2 e eae foram detectados em $4(12,9 \%)$ e $3(9,67 \%)$ das amostras.

Cabe ressaltar que em uma das amostras de E. coli houve a detecção simultânea dos genes codificadores de Stx1 e eae.

Não foi detectada a presença de genes codificadores de fatores de virulência ou adesinas em 17 (58,62\%) das 29 colônias de E. coli isoladas. 


\subsubsection{Quarta colheita (C4)}

Em fevereiro e março de 2010, foram colhidas as amostras dos bezerros, na ocasião do desmame dos mesmos. Observaram-se $5(16,12 \%)$ animais com diarréia, no momento da colheita e a média de idade desses animais era de 149 dias.

\subsubsection{Exame virológico}

Não foi detectada a presence de BCoV, nem de RV-A do grupo A nas amostras investigadas.

\subsubsection{Exame coproparasitológico}

Nessa quarta colheita, nenhuma amostra foi diagnosticada negativa ao exame coproparasitológico. Detectaram-se oocistos de Eimeria spp em 30 (96,78\%) animais, nas seguintes quantidades: raros (28 - 90,32\%), 2 cruzes $(1-3,23 \%)$ e 5 cruzes $(1-3,23 \%)$. Detectaram-se, ainda, raros ovos de helmintos da superfamília Strongyloidea ( 9 - 29,03\%), e raros ovos de helmintos dos gêneros Trichuris spp (6 - 19,35\%) e Strongyloides spp (3 - 9,68\%). O resumo dos resultados obtidos conta na Tabela 20. 
Tabela 20 - Parasitas identificados por exame coproparasitológico em amostras fecais de bezerros de corte na quarta colheita realizada na fazenda com casos recorrentes de diarréia. São Paulo, 2010

\begin{tabular}{lcc}
\hline & Coproparasitológico Final \\
\hline Parasita & Quant. & $\%$ \\
\hline Negativo & 0 & $0,00 \%$ \\
Eimeria spp & raros & $90,32 \%$ \\
Eimeria spp & ++ & $3,23 \%$ \\
Eimeria spp & +++++ & $3,23 \%$ \\
Strongyloidea & raros & $29,03 \%$ \\
Trichuris & raros & $19,35 \%$ \\
Strongyloides & raros & $9,68 \%$ \\
\hline
\end{tabular}

Houve divergência no diagnótico obtido pelas duas técnicas utilizadas no presente trabalho em $11(35,5 \%)$ amostras examinadas.

O método de Sheater foi mais sensível na detecção de oocistos de Eimeria spp em: 3 amostras, detectando raros oocistos desse cocídio em amostras negativas pelo método de Ritchie; 1 amostra, quantificando os oocistos em 2 cruzes, quando o outro método os quantificou em raros; e, finalmente, 1 amostra, quantificando os oocistos em 5 cruzes, quando o outro método os quantificou em 4 cruzes. A centrífugo-flutuação em solução supersaturada de sacarose detectou, ainda, raros ovos de Strongyloidea em 4 amostras e raros ovos de Trichuris spp em 2 amostras diagnosticadas negativas pelo método de Ritchie.

O método de centrífugo sedimentação em água-éter detectou a presença de raros ovos de Strongyloidea em 2 amostras e raros ovos de parasitas dos gêneros Trichuris spp (4) e Strongyloides (2) em amostras diagnosticadas negativas pelo método de Sheater.

A Tabela 21 contém os dados acima referida. 
Tabela 21 - Parasitas identificados por exame coproparasitológico em amostras fecais de bezerros de corte na segunda colheita realizada na fazenda com casos esporádicos de diarréia. São Paulo, 2008-2009

\begin{tabular}{|c|c|c|c|c|c|}
\hline \multicolumn{6}{|c|}{ Resultados obtidos pelos diferentes métodos } \\
\hline \multicolumn{3}{|c|}{ Água-Éter } & \multicolumn{3}{|c|}{ Sacarose } \\
\hline Parasita & Quant. & $\%$ & Parasita & Quant. & $\%$ \\
\hline Negativo & 0 & $12,90 \%$ & Negativo & 0 & $3,23 \%$ \\
\hline Eimeria spp & raros & $80,65 \%$ & Eimeria spp & Raros & $90,32 \%$ \\
\hline Eimeria spp & ++ & $0,00 \%$ & Eimeria spp & ++ & $3,23 \%$ \\
\hline Eimeria spp & ++++ & $3,23 \%$ & Eimeria spp & ++++ & $0,00 \%$ \\
\hline Eimeria spp & ++++ & $0,00 \%$ & Eimeria spp & ++++ & $3,23 \%$ \\
\hline Strongyloidea & raros & $16,13 \%$ & Strongyloidea & Raros & $22,58 \%$ \\
\hline Trichuris & raros & $12,90 \%$ & Trichuris & Raros & $6,45 \%$ \\
\hline Strongyloides & raros & $12,90 \%$ & Strongyloides & Raros & $3,23 \%$ \\
\hline
\end{tabular}

\subsubsection{Exame bacteriológico}

Dos 31 swabs colhidos, isolaram-se 76 colônias de bactérias distintas. Foram isoladas $26(83,87 \%)$ E. coli no total, sendo que 7 (22,58\%) em colônia pura. Além disso, verificou-se o co-isolamento de E. coli e outras espécies de enterobactérias em 17 (54,84\%) amostras, e o co-isolamento de enterobactérias, sem a detecção de E. coli em $7(22,58 \%)$ das amostras examinadas.

As espécies de enterobactérias isoladas incluem: Aeromonas hydrophila, Citrobacter amalonaticus, Citrobacter diversus, Edwarsiella hoshinae, Edwarsiella tarda biogrupo I, Enterobacter spp, Klebsiella pneumoniae subesp. azanae, Klebsiella pneumoniae subesp. pneumoniae, Klebsiella pneumoniae subesp. rinoscleromatis, Serratia spp, Yersinia spp. Os dados referntes aos isolamentos bacterianos das amostras da quarta colheita estão apresentados na Tabela 22. 
Tabela 22 - Espécies de bactérias isoladas de swabs retais de bezerros de corte na quarta colheita realizada na fazenda com casos recorrentes de diarréia. São Paulo, 2010

\begin{tabular}{lc}
\hline Bactéria & $\%$ \\
\hline E. coli & $22,58 \%$ \\
E. coli + 1 espécie de enterobactéria & $3,23 \%$ \\
E. coli + 2 espécie de enterobactéria & $32,26 \%$ \\
E. coli + 3 espécie de enterobactéria & $19,35 \%$ \\
+ de 1 espécie de enterobactéria sem a presença de E. coli & $22,58 \%$ \\
\hline Total & $\mathbf{1 0 0 , 0 0 \%}$ \\
\hline
\end{tabular}

4.2.4.3.1 Detecção de fatores de virulência de E. coli

Pela Multiplex-PCR empregada nesse trabalho, detectou-se a presença do gene codificador da Stx1 em 4 (12,9\%) das amostras investigadas, tendo sido uma proveniente de $E$. coli isolada em cultura pura. O mesmo ocorreu para 1 das 2 amostras $(6,45 \%)$ nas quais foi detectado o gene codificador da Stx2. Por fim, foi verificada a presença do gene para eae em duas (6,45\%) amostras.

Em 20 (76,92\%) das 26 colônias E. coli isoladas não foi verificada a presença de nehhum dos genes pesquisados.

\subsection{COMPARAÇÃO DE RESULTADOS}

4.3.1 Comparação entre colheitas realizadas na fazenda com casos esporádicos de diarréia (fazenda 1) 
$\mathrm{Na}$ fazenda com casos esporádicos de diarréia, foi possível observar que os casos de enterite concentraram-se na segunda colheita de amostras, para ambos os lotes investigados (C2L1 e C2L2).

Quanto à freqüência de ocorrência do BCoV foram detectados em amostras de animais do segundo lote na primeira colheita (C1L2) e em animais de ambos os lotes da segunda colheita (C2L1 e C2L2).

A detecção dos rotavírus, por sua vez, ocorreu exclusivamente em amostras colhidas de animais pertencentes ao segundo lote de animais, nas 3 primeiras colheitas (C1L2, C2L2 e C3L2).

Com relação ao exame coproparasitológico, não foi observada infecção nos animais neonatos (C1L1 e C1L2). Entretanto pode-se observar um aumento na freqüência de ocorrência de parasitas na segunda e terceira colheitas, com uma tendência a decréscimo na colheita 4.

Um perfil semelhante foi verificado quanto à freqüência de ocorrência de $E$. coli portadora de genes codificadores de fatores de virulência, havendo ausência desses tipos de colônias bacterianas em animais neonatos, uma aumento de sua freqüência de ocorrência nas amostras das colheitas 2 e 3 e uma tendência de redução de sua detecção na última colheita.

Os dados descritos anteriormente estão apresentados na Figura 8.

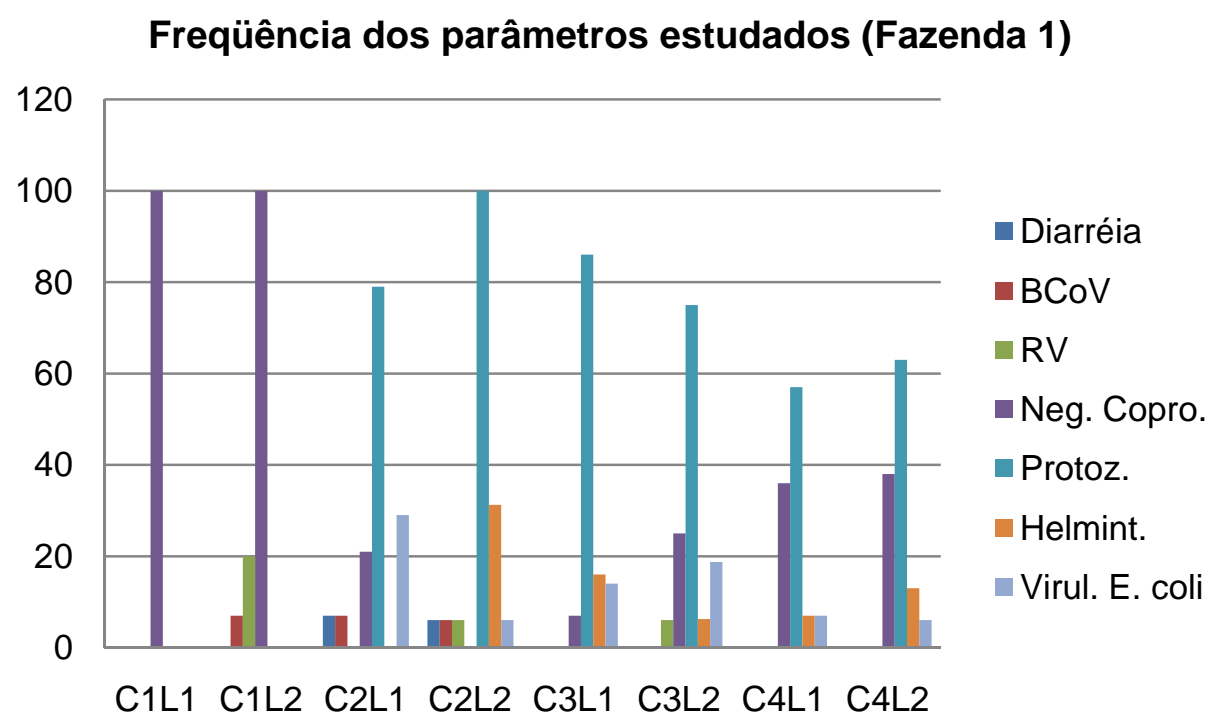

Figura 8 - Freqüência de ocorrência de diarréia, coronavírus bovino (BCoV), rotavírus do grupo $V$ (RV-A), amostras negativas ao exame coproparasitológico, protozoários, helmintos e E. coli portadora de genes codificadores para fatores de virulência nas 4 colheitas realizadas $(1,2,3$ e 4) nos dois lotes de animais (L1 e L2), na propriedade com casos esporádicos de diarréia 
Quanto aos genes codificadores de fatores de virulência pesquisados,detectaram-se os genes para Stx1, eae e K99. O gene para K99 foi detectado exclusivamente em amostras dos animais pertencentes ao lote 1, na segunda colheita realizada (C2L1). O gene codificador da Stx1foi detectado em colônias de E. coli isoladas de animais de ambos os lotes nas três últimas colheitas (C2, C3 e C4), com uma tendência de aumento da terceira colheita (C3L1 e C3L2). Por fim, o gene para intimina oi detectado em amostras dos animais pertencentes ao lote 1 na segunda e quarta colheitas (C2L1 e C4L1) e em animais do lote 2 na terceira colheita. Os dados descritos nesse parágrafo estão resumidos na Figura 9.

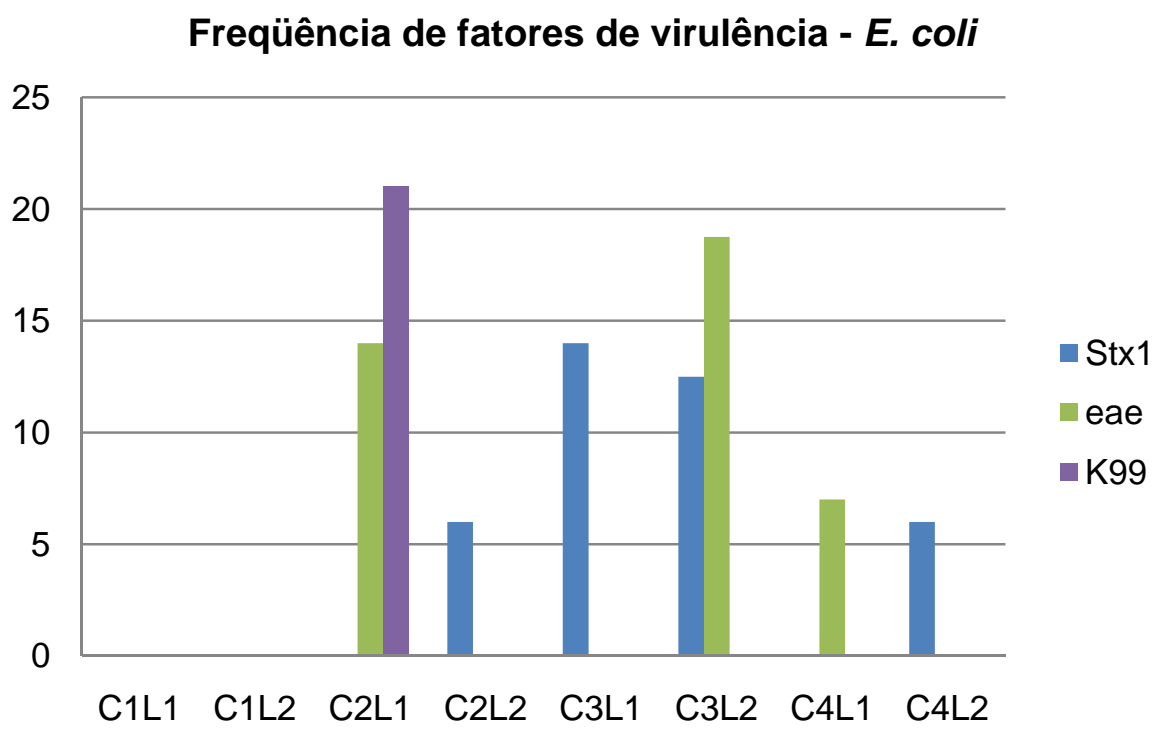

Figura 9 - Freqüência de ocorrência de genes codificadores de toxina Shiga-like 1(Stx1), intimina (eae) e adesina K99 em colônias de E. coli isoladas de amostras fecais de bezerros da propriedade com casos esporádicos de diarréia

\subsubsection{Comparação entre colheitas realizadas na fazenda com casos recorrentes de diarréia (fazenda 2)}

Nesta propriedade, observaram-se casos de diarréia nas 4 colheitas realizadas nos animais pertencentes ao lote 2 (C1L2, C2L2, C3L2 e C4L2), 
enquanto nos animais do lote 1 , observou-se a ocorrência de enterite apenas na primeira colheita (C1L1).

Quanto à detecção de vírus, foi detectado BCoV apenas na primeira colheita do lote 2 , e houve a detecção de rotavírus apenas em animais do lote 1 na primeira e segunda colheitas.

No que se refere infecções por parasitas e E. coli portadoras de genes codificadores de fatores de virulência, ocorreu a detecção destes microorganismos em ambos os lotes e em todas as colheitas, excetuando-se a infecção por helmintos nos animais do lote 2 na primeira colheita. (C1L2).

Os resultados acima descritos estão apresentados na Figura 10.

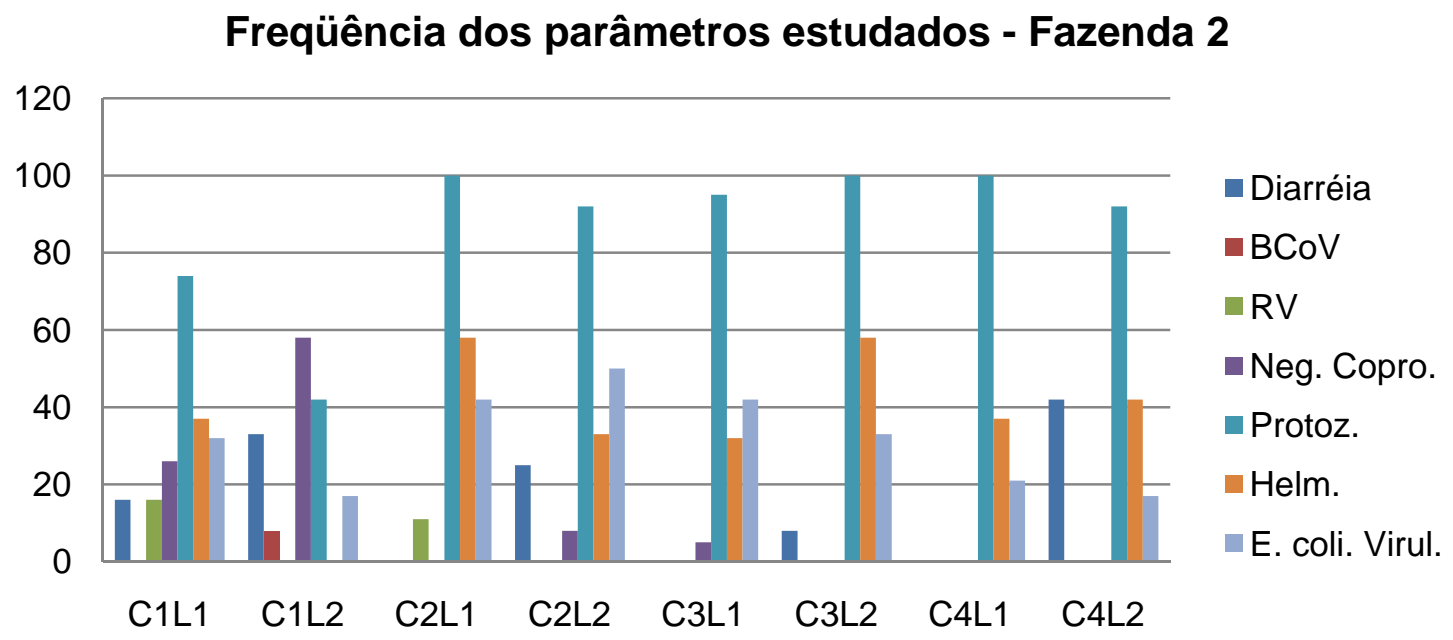

Figura 10 - Freqüência de ocorrência de diarréia, coronavírus bovino (BCoV), rotavírus do grupo $\mathrm{V}$ (RV-A), amostras negativas ao exame coproparasitológico, protozoários, helmintos e E. coli portadora de genes codificadores para fatores de virulência nas 4 colheitas realizadas (1, 2, 3 e 4) nos dois lotes de animais (L1 e L2), na propriedade com casos recorrentes de diarréia

Com relação à freqüência de detecção de genes codificadores de fatores de virulência nas $E$. coli isoladas, foram detectados os genes codificadores de Stx1, Stx2 e eae em amostras dos animais de ambos os lotes em todas as colheitas (Figura 11). 


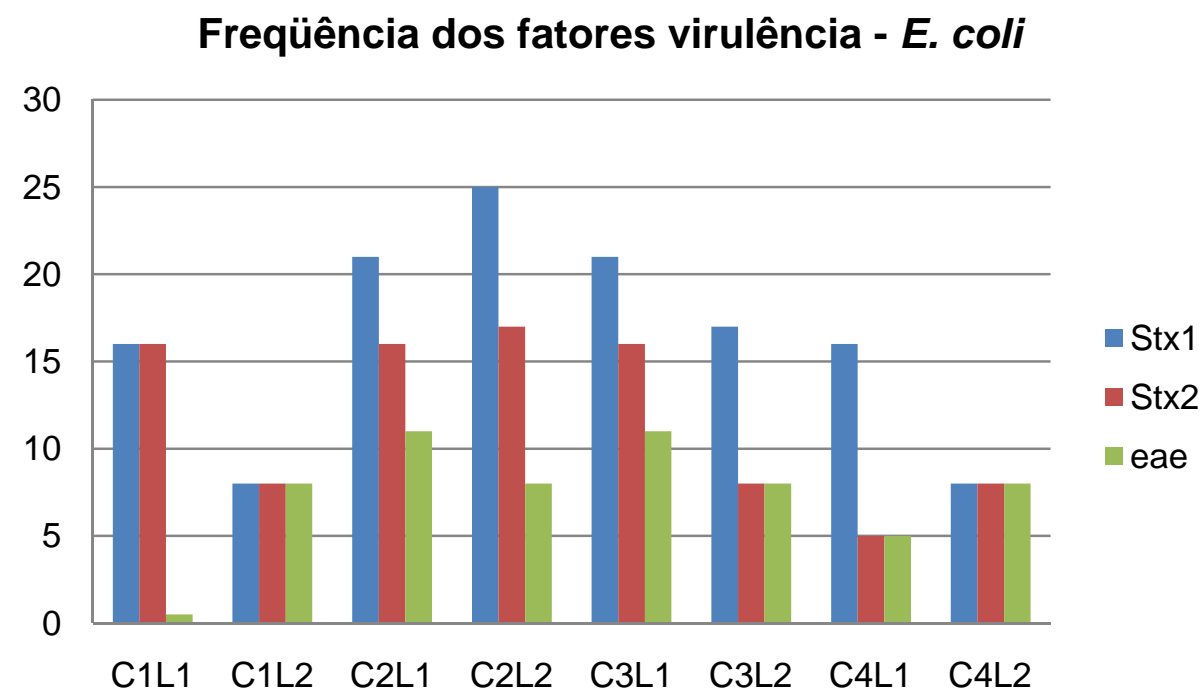

Figura 11 - Freqüência de ocorrência de genes codificadores de toxina Shiga-like 1 (Stx1), Shiga-like 2 (Stx2) e intimina (eae) em colônias de E. coli isoladas de amostras fecais de bezerros da propriedade com casos esporádicos de diarréia

\subsubsection{Comparação entre fazendas}

Comparando-se os resultados encontrados nas duas propriedades, observase que nas fazendas com casos esporádicos de diarréia, os mesmos concentraramse na segunda colheita de amostras, enquanto que os casos de diarréia na fazenda 2 ocorreram em todas as colheitas, excetuando-se a terceira colheita da lote 1, quando não foi verificado nenhum caso de diarréia, conforme apresentado na Figura 12. Além disso, é possível verificar que a freqüência de casos é superior na fazenda 2, em relação à propriedade com casos esporádicos da doença. 


\section{Freqüência Diarréia}

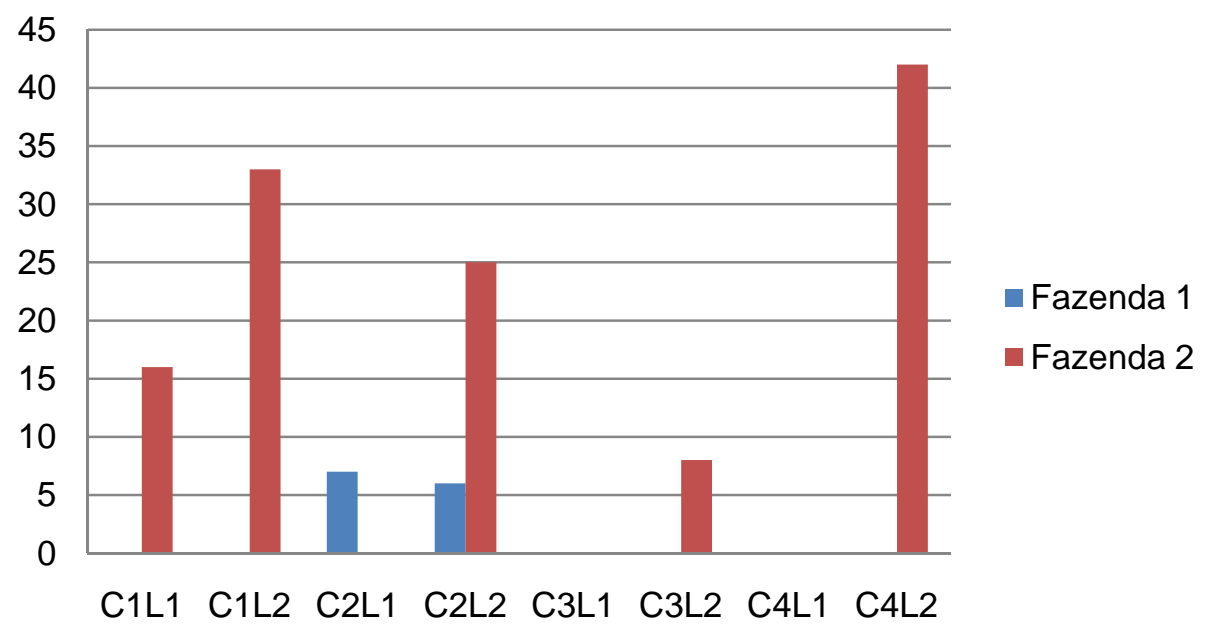

Figura 12 - Freqüência de ocorrência de casos de diarréia nas propriedades com casos esporádicos (fazenda 1) e recorrentes (fazenda 2) nos dois lotes (L1 e L2) de animais estudados, nas colheitas (C1, C2, C3 e C4)

Quanto à detecção de vírus, é possível perceber que tanto a detecção de $\mathrm{BCoV}$ quanto de RV-A, foi mais freqüente nas duas primeiras colheitas em ambas as propriedades, conforme ilustrado na Figura 13.

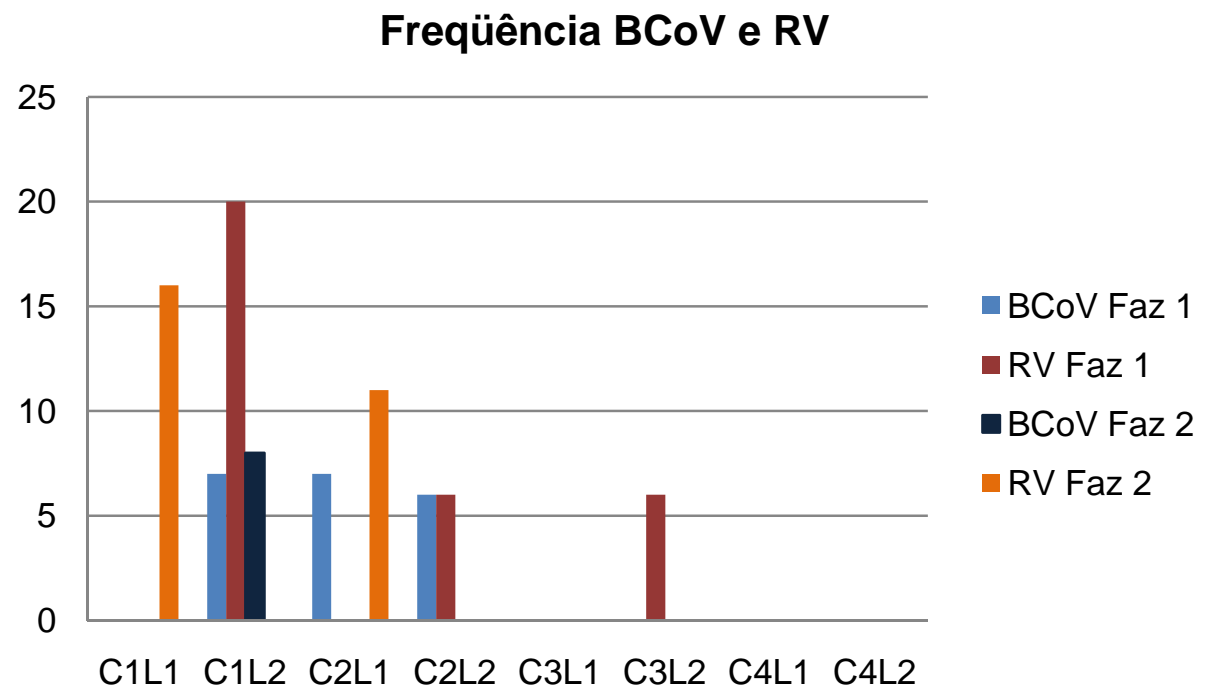

Figura 13 - Freqüência de ocorrência de coronavírus bovino $(B C o V)$ e rotavírus do grupo $A(R V-A)$ nas propriedades com casos esporádicos (fazenda 1) e recorrentes (fazenda 2) nos dois lotes (L1 e L2) de animais estudados, nas colheitas (C1, C2, C3 e C4) 
Com relação à infecção por parasitas, observa-se que, na maioria das colheitas, a freqüência de amostras negativas ao exame coproparasitológico foi superior na fazenda com casos esporádicos de diarréia, excetuando-se a segunda colheita do lote 2(C2L2).

De modo complementar, nota-se também que a freqüência de detecção de parasitas nas amostras da fazenda 2 foi superior, com relação à fazenda 1, na maioria das colheitas, excetuando-se a detecção de protozoários nas amostras da segunda colheita dos animais do L2, na qual a freqüência de protozoários foi maior na fazenda 1, em comparação à fazenda com casos recorrentes.

Os resultados acima descritos estão compilados na Figura 14.

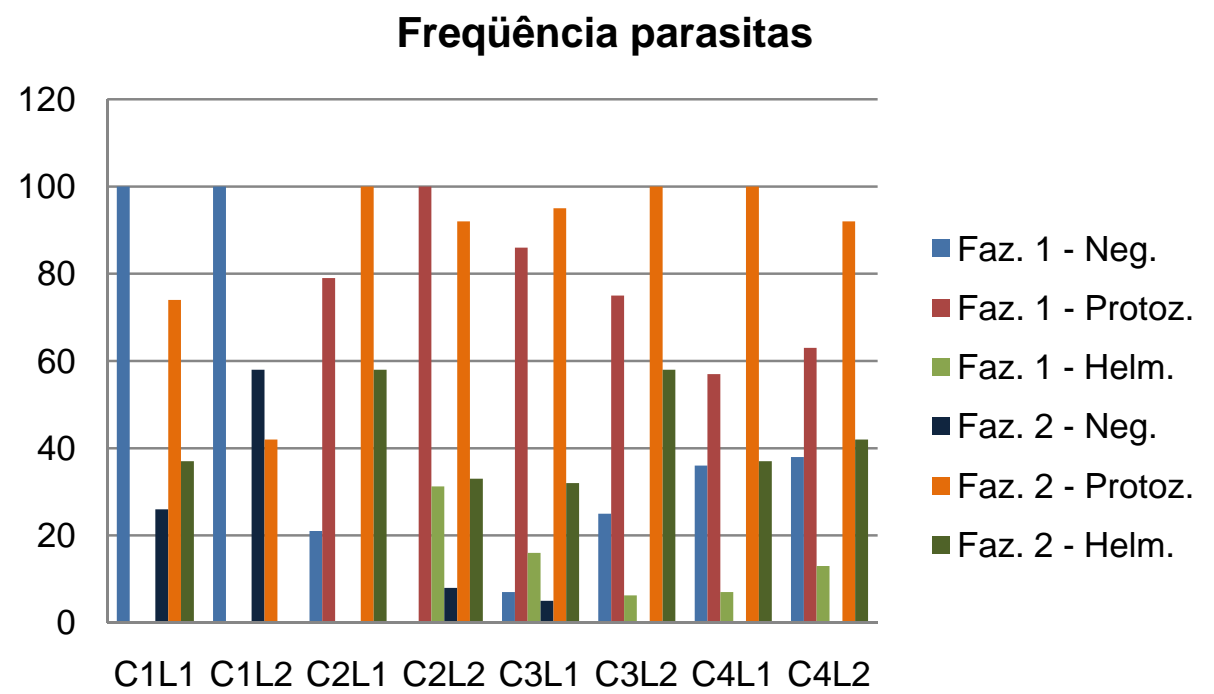

Figura 14 - Freqüência de ocorrência de amostras negativas (Neg.) e positivas para protozoários (Protoz.) e helmintos (Helm.) nas propriedades com casos esporádicos (fazenda 1) e recorrentes (fazenda 2) nos dois lotes (L1 e L2) de animais estudados, nas colheitas (C1, $\mathrm{C} 2, \mathrm{C} 3$ e C4)

Considerando-se a freqüência de detecção $E$. coli portadora de genes codificadores para os fatores de virulência investigados observa-se que, em ambos os lotes e em todas as colheitas realizadas, a detecção foi superior na fazenda com casos recorrentes de diarréia, em relação à fazenda 1, conforme Figura 15. 
Freqüência de $E$. coli virulenta

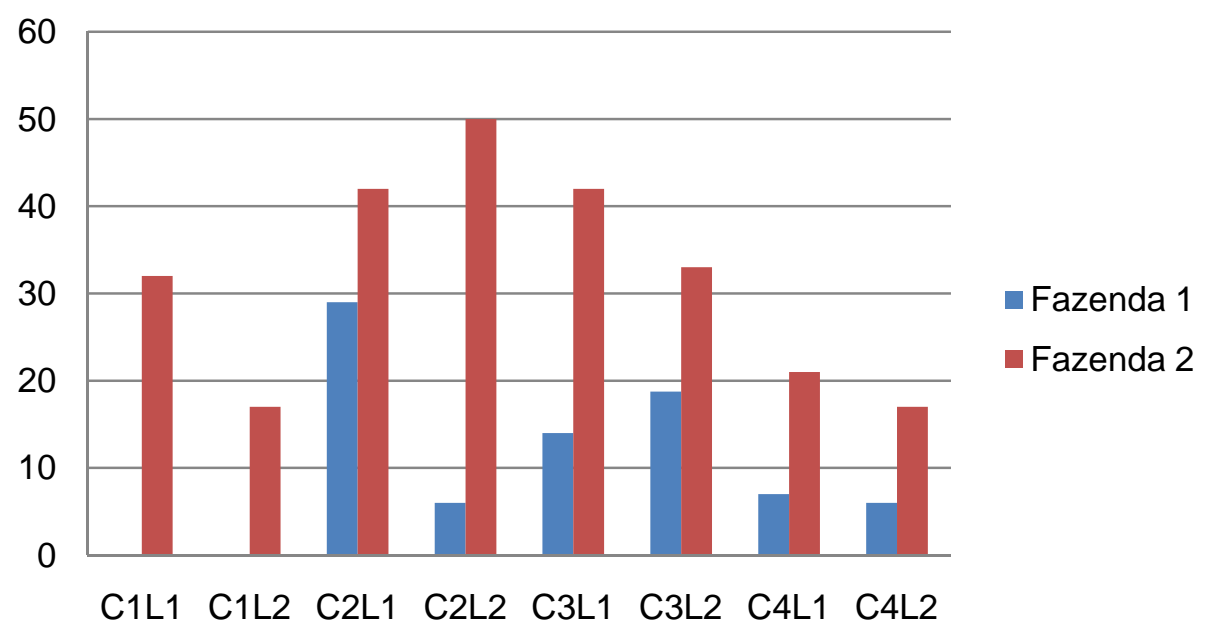

Figura 15 - Freqüência de ocorrência de E. coli portadora de genes codificadores de fatores de virulência nas propriedades com casos esporádicos (fazenda 1) e recorrentes (fazenda 2) nos dois lotes (L1 e L2) de animais estudados, nas colheitas (C1, C2, C3 e C4)

Por fim, considerando-se os fatores de virulência detectados nas E. coli isoladas, foi verificada a ocorrência dos genes codificadores de Stx1 e eae em ambas as propriedades. Além disso, detectou-se o gene para K99 apenas na fazenda 1 e do gene para Stx2 apenas na fazenda 2. A Figura 16 ilustra as freqüências de ocorrências encontradas para cada um dos genes. 


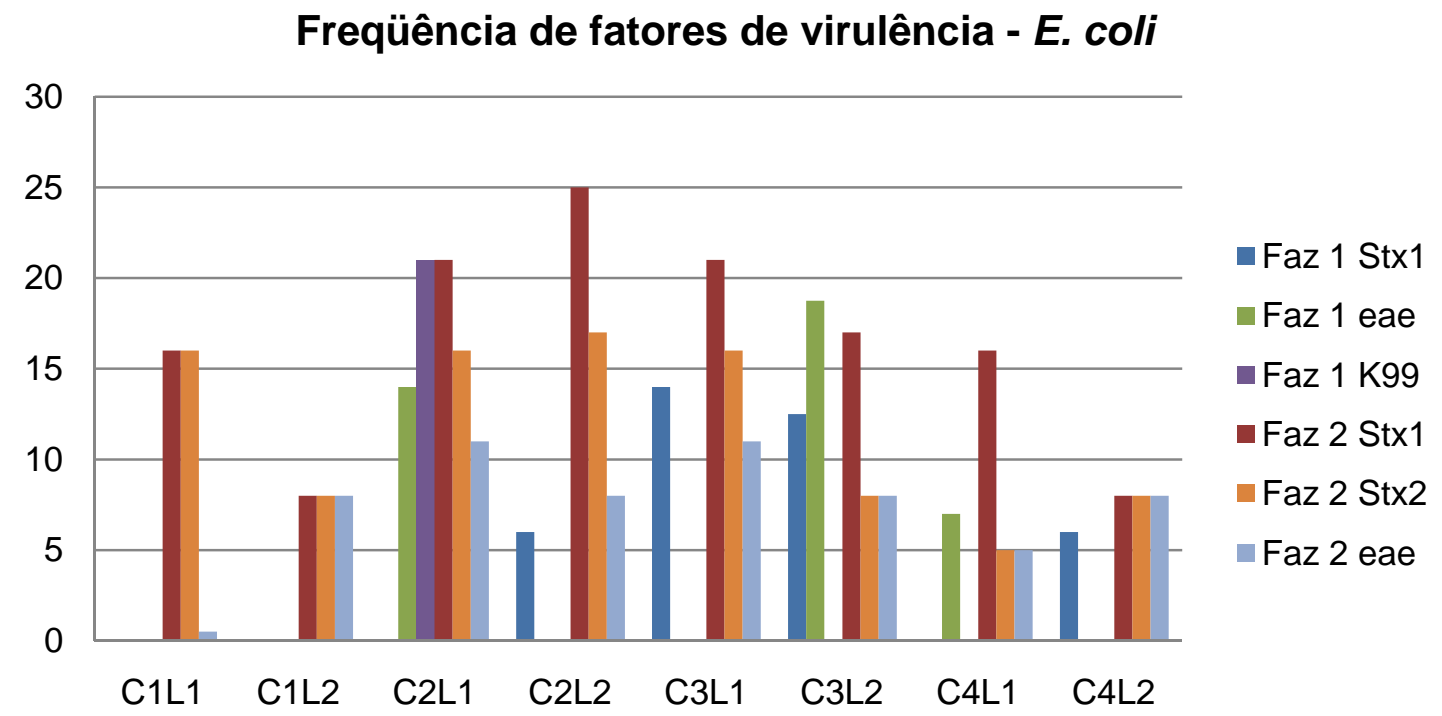

Figura 16 - Freqüência de ocorrência de genes codificadores de toxina Shiga-like 1(Stx1), toxina Shiga-like2 (Stx2) intimina (eae) e adesina K99 em colônias de E. coli isoladas de amostras fecais colhidas nas propriedades com casos esporádicos (fazenda 1) e recorrentes (fazenda 2) nos dois lotes (L1 e L2) de animais estudados, nas colheitas (C1, $\mathrm{C} 2, \mathrm{C} 3$ e C4)

\subsection{ANÁLISE DOS RESULTADOS}

Utilizando-se o programa Minitab (Minitab Versão $14.1^{\circledR}$ 1972-2003, Minitab INC), aplicou-se o teste de Fisher para se compararem as freqüências de ocorrência de infecções por parasitas nos animais com e sem diarréia, pertencentes às 2 fazendas, não tendo sido verificada diferença estatística entre as mesmas $(p=0,784)$. O mesmo teste foi empregado para verificar se foi significante a diferença entre a freqüência de detecção de E. coli virulenta em amostras diarréicas e não diarréicas, novamente não foi verificada diferença estatisticamente significante $(p=0,546)$.

Foi empregado o teste de Chi-quadrado para compararem-se as freqüências de ocorrência de parasitas e E. coli virulenta entre as propriedades. Verificou-se uma diferença significante tanto entre a freqüência de ocorrência de parasitas $\left(X^{2}=37,19\right.$, $\mathrm{p}=0,000)$ quanto de $E$. coli virulenta $\left(X^{2}=208,810, p=0,000\right)$, entre a propriedade com casos esporádicos de diarréia e àquela com casos recorrentes, para a qual as freqüências foram mais elevadas. 
DISCUSSÃO 


\section{DISCUSSÃO}

$\mathrm{Na}$ presente investigação, agente patogênicos comumente associados a enterite em gado de corte foram investigados de modo longitudinal por um período de dez meses em uma fazenda com casos esporádicos e sete meses em outra com casos recorrentes de diarréia em bezerros, encontrando-se diferenças relacionáveis às idades dos animais amostrados e às condições sanitárias em casa fazenda.

Em relação ao coronavírus bovino e aos rotavírus do grupo $A$, a freqüência de ocorrência foi baixa, encontrando-se raros casos de animais positivos nas duas fazendas, sendo que não houve nenhuma detecção destes vírus em animais com idade superior ou igual a 149 dias (figura 13).

BCoV e rotavírus são patógenos associados com grande freqüência em casos de diarréias em bovinos, sobretudo em neonatos (BOILEAU; KAPIL, 2010; STIPP et al., 2009; OLIVEIRA FILHO et al., 2007; BUZINARO et al., 2003; JEREZ et al., 2002), mas, também em animais adultos (BRANDÃO et al., 2007) sendo raros em animais sadios, com poucos relatos desta detecção (STIPP et al., 2009).

Assim sendo, uma vez que entre os animais amostrados no presente estudo raros se apresentaram com diarréia, dentre os quais apenas dois para os quais se detectaram rotavírus e coronavírus, pode-se sugerir que estes patógenos, ainda que presentes na população estejam em baixa freqüência em contaminação ambiental.

A detecção destes vírus em animais mais velhos, como aqueles das colheitas 2 e 3 de ambas fazendas (figura 13) pode elevar a probabilidade de que estes animais se comportem como importantes fontes de infecção para animais mais jovens, mais susceptíveis à manifestação de enterites.

Entretanto, a maior parte dos estudos publicados em coronavírus bovino e rotavírus refere-se a rebanhos leiteiros, sendo raros aqueles em gado de corte (STIPP et al., 2009; OLIVEIRA FILHO et al., 2007; BUZINARO et al., 2003).

Em um estudo realizado em gado de corte do Estado de São Paulo, criado em modalidade semi-extensiva, investigou-se a presença de rotavírus, por eletroforese em gel de poliacrilamida (PAGE) e ensaio imunoenzimático (ELISA) em amostras fecais de bezerros apresentando diarréia, durante três estações de parição 
consecutivas, tendo se encontrado rotavírus do grupo A em 63,8\% (44/69) das amostras investigadas (BUZINARO et al., 2003).

Deve-se considerar, entretanto, que no trabalho supracitado, todos os animais amostrados apresentavam diarréia no momento da colheita, o que pode de fato ter sido a causa da elevada detecção de rotavírus quando em comparação com os resultados aqui apresentados, visto que, neste caso, a maioria dos animais era de assintomáticos à colheita.

Paralelamente, em um levantamento realizado em amostras fecais de bezerros de corte e de leite, com até 60 dias de idade, provenientes das regiões Sul, Sudeste e Centro-Oeste do Brasil, utilizou-se uma semi-nested PCR para detecção de coronavírus bovino, tendo sido encontrado BCoV em 15,6\% (44/282) das amostras, sendo que 95,4\% delas (42/44) eram diarréicas e 4,6\% (2/44) eram normais, tendo-se associado a presença do vírus com sinais clínicos de diarréia, e havendo maior freqüência de ocorrência em animais entre 16 e 30 dias de idade (STIPP et al., 2009).

Sabe-se que a excreção de agentes virais em animais com diarréia ocorre com títulos mais elevados no início do aparecimento dos sintomas, estimando-se que a eliminação nas primeiras horas seja da ordem de $10^{8}-10^{9}$ partículas virais/mL de fezes, caindo progressivamente (JEREZ, 2006). Para coronavírus, em animais experimentalmente infectados, foi verificada a excreção viral em altos títulos por apenas 3 dias e, posteriormente, a excreção intermitente e em baixos títulos (KAPIL; TRENT; GOYAL, 1990).

Assim, ainda que as idades dos animais nos quais se detectaram rotavírus do grupo $\mathrm{A}$ e $\mathrm{BCoV}$ no presente estudo sejam compatíveis com àquelas já descritas para infecções por estes vírus, a amostragem de animais sadios no presente estudo é a mais provável causa da baixa freqüência de detecção.

Nota-se que para as cinco amostras de BCoV detectadas pela RT-PCR de triagem para o gene codificador da RNA-polimerase RNA-dependente,presente na ORF1, nenhuma resultou no amplicon esperado de 488pb para a região codificadora da subunidade S1 da proteína $S$, o que impediu que se realizassem estudos de diversidade molecular para este vírus em gado de corte.

Uma das razões mais prováveis para explicar esta discrepância é que a RTPCR utilizada para a triagem já foi demonstrada como sendo mais sensível do que 
aquela para o gene S (BRANDÃO, 2004), principalmente em função do menos intenso polimorfismo encontrado na ORF1 de BCoV (MASTERS, 2006).

Observando-se a freqüência de detecção de helmintos e coccídeos, nota-se (Figura 14) uma tendência ascendente de acordo com a idade dos animais amostrados, com uma queda na freqüência na última das colheitas para a fazenda com casos esporádicos de diarréia.

Sabe-se que a imunidade contra parasitas em é dependente da concentração de imunoglobulinas colostrais, a qual decresce até os 60 dias pós-parto, enquanto que, para gado leiteiro, este período é de 60 dias (VETTORATO et al., 2009).

Somando-se a isto o fato de que a exposição continuada dos bezerros às pastagens contaminadas leva a um mais intenso desafio parasitário, pode-se propor que a tendência crescente inicial na freqüência de helmintos nesta fazenda seja e vida à associação das primo-infecções à imunidade ainda em desenvolvimento a qual, uma vez estabelecida, contaria para o decréscimo na freqüência quando os animais estavam com 239 dias de idade na quarta colheita.

Entretanto, observando-se a freqüência de parasitas para a fazenda com casos recorrentes de diarréia, ainda que a mesma tendência ascendente tenha sido observada com a progressão das idades dos animais, não se observou queda para os animais mais velhos (149 dias), ao contrário do que foi observado para a fazenda 1.

Este achado é concordante com o fato de ter sido detectada diferença estatisticamente significativa para a freqüência de ocorrência de parasitas entre as duas fazendas, quando tal freqüência foi superior para aquela com casos recorrentes de diarréia.

Observando-se as diferenças de manejo e de sanidade entre as duas fazendas, podem-se sugerir como variáveis associáveis a esta maior freqüência uma mais elevada densidade populacional, ausência de separação de animais por idades e qualidade da dieta das vacas em gestação e lactação.

Por exemplo, em uma investigação realizada em rebanhos leiteiros, na Noruega, apontaram-se os seguintes fatores de risco para diarréia: alta densidade animal, especialmente em aglomerados de vacas e bezerros (fato que poderia promover a disseminação de agentes infecciosos e aumentar a infecção ambiental), aumento da tecnificação da produção (o que poderia reduzir a atenção diária a cada animal), nascimento em estações frias e úmidas (que aumentam a viabilidade de 
patógenos no ambiente) e a qualidade do colostro produzido (potencialmente pior em estações de privação de alimento, contendo concentrações inferiores de IgGs) e seu adequado consumo pelos neonatos (GULLIKSEN et al., 2009).

No Rio Grande do Sul, investigou-se a influência do clima sobre a viabilidade de parasitas em pastagens, monitorando-se o número de ovos por grama de fezes em bezerros de corte criados extensivamente, com idade média de 5 meses, e o número de larvas nas pastagens, em intervalos de 15 dias. Esse estudo encontrou aumento significativo da infecção por Eimeria spp e Strongyloidea nas sucessivas colheitas, e os autores o associaram ao aumento de parasitas infectantes nas pastagens e ao aumento do índice pluviométrico no referido período, e as alterações de temperaturas não influenciaram na contagem de parasitas (HECK et al., 2005).

Assim, como na fazenda com casos recorrentes de diarréia não havia estação de parição controlada, o nascimento de bezerros em épocas do ano nas quais a qualidade nutricional dos alimentos fosse menor e a viabilidade dos patógenos no meio ambiente fosse prolongada, como em meses de inverno, com menores temperatura e incidência de luz ultra-violeta, pode ter favorecido não só a recorrência de casos mas também a manutenção de uma mais elevada carga parasitária no ambiente.

Apoiando esta hipótese de mais intensa carga parasitária ambiental fator de risco em detrimento da causalidade entre parasitas e diarréia, nota-se que, ainda que na fazenda com casos recorrentes de diarréia a freqüência de animais positivos tenha sido superior com significância estatística, a diferença entre animais com e sem diarréia positivos para a presença de helmintos ou protozoários, contabilizados entre as duas fazendas, não foi estatisticamente significativa, sugerindo que a presença de fatores predisponentes como imunossupressão poderiam desencadear infecções sintomáticas.

Foi notável, no presente estudo, a ausência de qualquer animal positivo para a presença de oocistos de Cryptosporidium spp. Ainda que este seja um patógeno já descrito como importante para diarréia em bezerros (OLIVEIRA FILHO et al., 2007) sua pesquisa em amostras fecais é imperativa, dada a relevância deste protozoário em Saúde Pública.

Observando-se os resultados dos exames bacteriológicos para as duas propriedades amostras, nota-se que a diversidade das espécies bacterianas encontradas progrediu com a idade dos animais. 
Inicialmente, pode-se sugerir que este achado seja devido ao perfil e à progressão da formação da microbiota entérica nos bovinos, uma vez que enterobactérias fazem parte da microbiota de bovinos saudáveis e espera-se que a mesma tenha sua complexidade elevada com a continuidade da exposição dos animais às bactérias presentes no meio ambiente.

Observando-se o anexo A, entretanto, nota-se que houve casos nos quais culturas puras de bactérias foram isoladas, como, por exemplo, Salmonella spp, Serratia spp e, em maioria, E. coli, tanto em animais com diarréia quanto em animais saudáveis.

Pode-se sugerir que estes achados sejam devidos à competição entre as espécies de bactérias durante seu isolamento, prevalecendo aquela que estivesse em maior contagem inicial, indicando uma menos complexa microbiota entérica.

Pode-se, com isto, especular que, em alguns casos para os quais se obtiveram isolamentos de culturas puras representem animais nos quais houve favorecimento da expansão populacional determinada espécie bacteriana que poderia resultar em diarréia caso a população bacteriana da espécie em questão continuasse em ascensão ou fatores predisponentes como co-infecções virais ou parasitárias e estresse de manejo.

Deve-se considerar, ainda, que alguns destes casos de isolamento de culturas bacterianas puras de E. coli, estes achados podem ser simplesmente devidos ao fato de que esta espécie é uma das primeiras a colonizar o trato gastrointestinal de bovinos (FOSTER; SMITH, 2009).

Com relação aos isolamentos de Salmonella spp tanto no caso em cultura pura quanto naqueles casos nos quais a diversidade de espécies foi maior (Anexo A), ainda que os animais em questão não apresentassem diarréia no momento da colheita, deve-se considerar que as salmonelas são bactérias de relevância em Saúde Pública (OLIVEIRA FILHO et al., 2007) e que podem eventualmente levar a enterite em bezerros (LANGONI et al., 2004).

Para as colônias de $E$. coli nas quais se pesquisaram fatores de virulência e de adesão, encontraram-se os fatores Stx1, eae e K99 para a fazenda com casos esporádicos e Stx1 e 2 e eae para a fazenda com casos recorrentes de diarréia.

A presença de $E$. coli com os genes para Shiga-like toxinas simultaneamente ao gene para intimina (eae), encontrado em algumas das colônias aqui detectadas caracteriza bactérias capazes de levar a lesões de adesão e erosão (HORNITZKY et 
al., 2005; SALVADORI et al., 2003), associado a colite hemorrágica e síndrome urêmica-hemolítica em seres humanos (SALVADORI et al., 2003).

Com isso, uma vez que este padrão Stx e eae foi encontrado sem uma tendência em relação à presença ou não de diarréia nos animais do presente trabalho, deve-se considerar que as cepas de $E$. coli com estes fatores sejam, na verdade, de maior significado para a saúde dos tratadores em contato com estes animais ou para a cadeia de produção de carne, considerando manipuladores e consumidores dado o seu potencial zoonótico.

Para a cepa de $E$. coli na qual se encontraram simultaneamente os fatores K99 e eae (Anexo A), cabe a denominação de genótipo atípico de E. coli, já descrita como potencial patógeno para humanos com transmissão alimentar (HORNITZKY et al., 2005).

Para a maioria das colônias de E. coli isoladas nas duas fazendas amostradas, houve a detecção de apenas um dos seis fatores de virulência pesquisados; ainda que considerando apenas a colônia em questão o encontro de um único fator de virulência reduza seu potencial patogênico em um nível individual, a existência de mais de um fator de virulência em uma população de $E$. coli, ainda que em indivíduos diferentes, possibilitaria a troca de fatores de virulência entre $E$. coli por meio de conjugação e transformação, elevando a probabilidade da emergência de um genótipo de maior significado patológico.

Como o encontrado para o caso de parasitas (helmintos e protozoários), a freqüência de E.coli com pelo menos um fator de virulência ou adesão foi significativamente superior na fazenda com casos recorrentes de diarréia. Neste caso, pode-se propor que este achado possa ser interpretado como conseqüência do menor padrão sanitário nesta fazenda em comparação àquela com casos esporádicos, podendo-se considerar estes genes como marcadores de risco para a emergência de genótipos virulentos.

Deve-se considerar, finalmente, que o simples encontro de um determinado fator de virulência em uma colônia de E. coli não necessariamente significa que aquela é de fato uma colônia de bactérias patogênicas, sendo mais adequada a atribuição de potencial patógeno, isto devido ao fato de que nem sempre a presença de um determinado gene de virulência significa necessariamente que a proteína por ele codificada e que exerce de fato o papel patogênico esteja sendo expressa. 
O conjunto de primers utilizados no presente trabalho foi eleito para a pesquisa de fatores de virulência em função de terem os fatores em questão sido propostos como os mais freqüentemente isolados em $E$. coli de bezerros de corte (OK et al., 2009).

Todavia, deve-se considerar que algumas das cepas de E. coli aqui classificadas como não patogênicas podem na verdade ser portadoras de fatores outros não previstos neste conjunto de primers, tanto em função de diversidade molecular dos genes codificadores destes fatores ou pela presença de outros fatores não pesquisados.

Assim sendo, para uma mais aprofundada elucidação do potencial patogênico das E. coli aqui encontradas, sugere-se pesquisar a presença de genes codificadores de um mais diverso número de fatores de virulência, incluindo aqueles não descritos para bezerros de corte.

Estudos longitudinais sobre patógenos entéricos em gado de corte são raros, o que impossibilita que os resultados aqui obtidos sejam levados à comparação com situações epidemiológicas quer similares, quer diversas àquelas presentes nas populações estudadas.

Um dos exemplos é um estudo conduzido em gado de corte criado extensivamente, foram colhidas amostras de bezerros sadios e com diarréia, em uma propriedade localizada no estado do Mato Grosso do Sul, com o intuito de se investigar a presença de: Salmonella spp, Escherichia coli, rotavírus, coronavírus, Cryptosporidium spp e ovos de helmintos. Foi verificada a presença de enteropatógenos em 79\% das amostras diarréicas e em 70\% das não diarréicas. Nas amostras diarréicas, a $E$. coli foi o agente mais freqüentemente isolado (69\%), seguido por Cryptosporidium spp (30\%), coronavírus (16\%) e rotavírus (11\%). Entre as amostras colhidas de animais sadios, a $E$. coli foi novamente o agente mais encontrado (66,7\%), seguindo-se os Cryptosporidium spp (10\%) e coronavírus (3,3\%) (OLIVEIRA FILHO et al., 2007).

O presente trabalho colabora para a caracterização da microbiota entérica de bezerros, mas mantém abertas as questões relativas às diferenças específicas entre as biotas entéricas de bezerros sadios e com diarréia, enfatizando a importância de se realizarem mais estudos que investiguem simultaneamente diversos enteropatógenos potenciais nestes animais. 
Embora não se tenha esclarecido o papel direto de cada um dos enteropatógenos potenciais no desencadeamento dos quadros de diarréia, foi possível marcar algumas das diferenças que podem expor lotes de bezerros a um risco mais elevado de ocorrência de casos de diarréia, destacando-se as medidas de manejo como prováveis causas para a maior freqüência de detecção de protozoários, helmintos e E. coli portadoras de genes codificadores para fatores de virulência.

Por fim, o presente trabalho colaborou para a caracterização genotípica de colônias de $E$. coli isoladas de bezerros de corte do Brasil, nas quais encontraram-se padrões genéticos de relevância em Saúde Pública, como as E. coli produtora de toxina Shiga-like (STEC) dos tipo 1 e 2 e as E. coli aderentes-erosivas (AEEC), comumente associadas a quadros de a colite hemorrágica e síndrome urêmicahemolítica em seres humanos. Além de terem sido encontradas amostras atípicas, nas detectou-se, simultaneamente, K99 e eae.

Esses achados ressaltam a importância de se continuar investigando os potenciais reservatórios de E. coli potencialmente patogênica, com o intuito de se delinearem estratégias que previnam os agravos à saúde animal e humana. 
CONCLUSÕES 


\section{CONCLUSÕES}

A partir dos resultados obtidos e dos pontos notados na Discussão, podem feitas as seguintes conclusões:

- Nas populações de bezerros de bovinos de corte estudadas, a freqüência de ocorrência de coronavírus bovino e rotavírus do grupo A foi baixa, restrita a animais com até quatro meses de idade, enquanto que protozoários, helmintos e enterobactérias apresentaram tendência crescente em freqüência relacionada à progressão da idade dos animais.

- Em bezerros de corte, ocorrem os patotipos STEC, EAEC e um padrão atípico com os genes de K99 e eae.

Há associação entre baixo padrão sanitário e maior freqüência de ocorrência de Eimeria spp, Strongyloidea, Strongyloides spp, Trichuris spp e Escherichia coli portadora de fatores de virulência Stx1, Stx2, K99 e eae. 
REFERÊNCIAS 


\section{REFERÊNCIAS}

ABRAHAM, S.; KIENZLE, T. E.; LAPPS, W.; BRIAN, D. A.. Deduced sequence of the bovine coronavirus spike protein and identification of the internal proteolytic cleavage site. Virology, v.176, p.296-301, 1990.

AKASHI, H.; INABA, Y.; MIURA, Y.; TOKUHISHA, S.; SATO, K.. Properties of a coronavirus isolated from a cow with epizootic diarrhea. Veterinary Microbiology, v.5, p.265-276, 1980.

ALFIERI, A. F.; ALFIERI, A. A.; BARREIROS, M. A. B.; LEITE, J. P. G.; RICHTZENHAIN, L. J.. G and $P$ genotypes of group A rotavirus strains in calves in Brazil, 1996-1999. Veterinary Microbiology, v.99 p.167-173, 2004.

ASANO, K. M.. Detecção simultânea de coronavírus bovino e rotavírus do grupo A em amostras fecais de bovinos utilizando uma multiplex hemi-nested RT-PCR. Dissertação (Mestrado em Medicina Veterinária Preventiva e Saúde Animal) - Faculdade de Medicina Veterinária e Zootecnia, Universidade de São Paulo, São Paulo, 2009.

ATHANASSIOUS, R.; MARSOLAIS, G.; ASSAF, R.; DEA, S.; DESCOTEAUX, J. P.; DULUDE, S.; MONTPETIT, C.. Detection of bovine coronavirus and type A rotavirus in neonatal calf diarrhea and winter dysentery of cattle in Quebec: Evaluation of three diagnostic methods. Clin. Vet. J., v.35, p. 163-169, 1994.

BARBOSA, E. F.; FIGUEIREDO, H. C .P.; GARCIA, A. M.; LOBATO, Z. I. P.; LAGE, A. P.. Rotavírus do grupo A em bezerros lactentes no estado de Minas Gerais. Santa Maria, Ciência Rural, v.28, n.3, p.435-439, 1998.

BENESI, F. J.. Síndrome diarréia dos bezerros. Revista CRMV-ES, Vitória, v.2, n.3, p. 10-13, 1999.

BLANCO, M.; LAZO, L.; BLANCO, J. E.; DHABI, G.; MORA, A.; LOPEZ, C.; GONZALES, E. A; BLANCO J.. Serotypes, virulence genes, and PFGE patterns of enteropathogenic Escherichia coli isolated from Cuban pigs with diarrhea. Int. Microbiol., v.9, p.53-60, 2006.

BOILEAU, M. \& KAPIL, S.. Bovine Coronavirus Associated Syndromes. Vet. Clin. Food. Anim., v.26, n.1, p. 123-146, 2010. DOl:10.1016/j.cvfa.2009.10.003.

BRANDÃO, P. E.; GREGORI, F.; MONTELEONE, G. S.; SOARES, R. M.; ROSALES, C. A. R.; JEREZ; J. A.. Nested PCR assay for detection of bovine coronavirus S1 gene. São Paulo, Arq. Inst. Biol., v.70, n.1, p.1-3, 2003.

BRANDÃO, P. E.. Coronavírus bovino (BCoV): ocorrência, diversidade molecular e padronização de PCR para diagnóstico a partir de amostras fecais de bezerros com e sem diarréia criados em municípios dos Estados de São Paulo e Minas Gerais, Brasil. Tese (Doutorado em Medicina Veterinária Preventiva 
e Saúde Animal) - Faculdade de Medicina Veterinária e Zootecnia, Universidade de São Paulo, São Paulo, 2004.

BRANDÃO, P. E.; GREGORI, F.; VILLARREAL, L. Y. B.; RODRIGUEZ, C. A. R; SOARES, R. M.; JEREZ, J. A.. A nested polymerase chain reaction to bovine coronavirus diagnosis. Virus Reviews \& Research, v.10, n.1, p.45-49, 2005.

BRANDÃO, P. E., VILLARREAL, L. Y. B., DE SOUZA, S. L. P., RICHTZENHAIN, L. J., JEREZ, J. A.. Mixed Infections by bovine coronavirus, rotavirus and Cryptosporidium in an outbreak of neonatal diarrhea in beef cattle. São Paulo, Arq. Inst. Biol., v. 74, n.1, p.33-34, 2007.

BUZINARO, M. G.; MISTIERI, M. L. A.; CARVALHO, A. A. B.; SAMARA, S. I.; REGITANO, L. C. A.; JEREZ, J. A.. Prevalência de rotavírus do grupo A em fezes diarréicas de bezerros de corte em sistema semi-intensivo de produção. Arq. Bras. Med. Vet. Zootec., v.55, n.3, 2003.

CHOMKCYNSKI, P. A.. A reagent for the single-step simultaneous isolation of RNA, DNA and protein from the cell and tissues samples. Biotechniques, v.15, n.3, p.532537, 1993.

COLLINS, A. R.; KNOBLER, R. L.; POWELL, H.; BUCHMEIER, M. J.. Monoclonal antibodies to murine hepatitis virus-4 (strain JHM) define the viral glycoprotein responsible for cell attachment and cell-cell fusion. Virology, v.119, p.358-371, 1982.

CORNAGLIA, E. M.; BARRANDEGUY, M.; FIJTMAN, N.; SCHUDEL, A.. Enzymelinked immunosorbent assay, immunofluorescence test and eletrophoretic analysis os rotaviral RNA in the diagnosis and characterization of the bovine rotavirus. Rev. Lat. Am. Microbiol., v. 31, n.1, p.59-62, 1989.

DAUGSCHIES, A.; NAJDROWSKI, M.. Eimeriosis in cattle: current understanding. J. Vet. Med. B., v.52, p.417-427, 2005.

DE LA FUENTE, R.; GARCIA, A.; RUIZ-SANTA-QUITERIA, J. A.; LUZÓN, M.; CID, D.; GARCIA, S.; ORDEN, J. A.; GÓMEZ-BAUTISTA, M.. Proportional morbidity rates of enteropathogens among diarrheic dairy calves in central Spain. Preventive Veterinary Medicine, v.36, p.145-152, 1998.

DUBEY, J. P.; SPEER, C. A.; FAYER, R.. Cryptosporidiosis of Man and Animals. Boston, CRC Press, 1990. 199pp.

ESTES, M.; KAPIAKIAN, A. Z.. Rotaviruses. In: Fields Virology, $5^{\mathrm{a}}$ ed. Philadelphia: Lippincott WILLIAMS \& Wilkins, p.1918-1976, 2007.

FAGAN, J. G.; DWYER, P. J.; QUINLAN, J. G.. Factors that may affect the occurrence of enteropathogens in the feces of diarrheic calves in Ireland. Irish Vet. Journal., v.48, p.17-21, 1995. 
FABER, J. E.; KOLLMANN, D.; HEISE, A.; BAUER, C.; FAILING, K.; BÜRGER, H. J.; ZAHNER, H.. Eimeria infections in cows in the periparturient phase and their calves: oocyst excretion and levels of specific serum and colostrum antibodies. Vet.

Parasitol., v.104, p.1-17, 2002.

FAYER, R.; MORGAN, U.; UPTON, S. J.. Epidemiology of Cryptosporidium: transmission, detection and identification. International Journal for Parasitology, v.30, n.12-13, p.1305-1322, 2000.

FERREIRA, L. F.; MORTEO, R. E.; SILVA, J. R.. Padronização de técnicas para exame parasitológico de fezes. Jornal Brasileiro de Medicina, v.6, n.1, p.241-257, 1962.

FOSTER, D. M.; SIMTH, G. W.. Pathophysiology of diarrhea in calves. Vet. Clin. Food Anim., v.25, p.13-36, 2009. DOI: 10.1016/j.cvfa.2008.10.013

GARCIA, A.; RUIZ-SANTA-QUITERIA, J. A.; ORDEN, J. A.; CID, D.; SANZ, R.; GÓMEZ-BAUTISTA, M.; DE LA FUENTE, R.. Rotavirus and concurrent infections with other enteropathogens in neonatal diarrheic dairycalves in Spain. Comparative Immunology, Microbiology \& Infectious Diseases., v.23, p.175-183, 2000.

GULLIKSEN, S. M.; LIE, I. K.; HAMMES, I. S.; LOKEN, T.; AKERSTEDT, J.; OSTERAS, O.. Enteropathogens and risk factors for diarrhea in Norwegian dairy calves. J. Dairy Sci., v.52, p. 5057 - 5066, 2009. DOI: 10.3168/jds.2009-2080.

GULLIKSEN, S. M.; LIE, I. K.; SOLVEROD, L.; OSTERAS, O.. Risk factors associated with colostrums quality in Norwegian dairy cows. J. Dairy Sci., v. 91, p. 704 - 712, 2008. DOI: 10.3168/jds.2007-0450.

HECK, I.; LEANDRO, A. S.; LEITE, C. T.; GRINDI, J. K.; SOUZA, M. B. M.; DEPNER, R.; MOLENTO, M.B.. Efeito do clima sobre a infecção parasitária em bezerros e presença de larvas em manejo rotativo de pasto em Santa Maria, RS, Brasil. Ciência Rural, v. 53, n.6, p. 1461 - 1464, 2005.

HERRING, A. J.; INGLIS, N. F.; OJEH, C. K.; SNODGRASS, D. R.; MENZIES, J. D.. Rapid diagnosis of rotavirus infection by direct detection of viral nucleic aCID in silver-stained polyacrylamide gels. Journal of Clinical Microbiology, v.16, p.473477, 1982.

HOLT, J. G.; KRIEG, N. R.; SNEATH, P. H. A.; STALEY, J. T.; WILLIAMS, ST.. Bergey's Manual of determinative bacteriology, 9th ed. WILLIAMS \& Wilkins, Baltimore, 1994.

HORNITZKY, M. A.; MERCIECA, K.; BETTELHEIM, K. A.; DJORDJEVIC, S. P.. Bovine feces from animals with gastrointestinal infections are a source of serologically diverse atypical enteropathogenic Escherichia coli and shiga toxin producing E. coli strains that commonly posses intimin. Applied and Environmental Microbiology, p.3405-3412, 2005. DOI: 10.1128/aem.71.7.3412.2005 
HOUSE, J. A.. Economic impact of rotaviruses and other neonatal disease agents of animals. Journal of American Veterinary Medical Association, v.173, n.5, p.573576, 1978.

JÄGER, M.; GAULY, M.; BAUER, C.; FAILING, K.; ERHARDT, G.; ZAHNER. H.. Endoparasites in calves of beef cattle herds: Management systems dependent and genetic influences. Veterinary Parasitology, v.191, p.131-173. 2005.

JEREZ, J. A.. Diarréias virais dos bovinos: rotavirose e coronavirose. Tese (Livre Docência em Medicina Veterinária Preventiva e Saúde Animal) - Faculdade de Medicina Veterinária e Zootecnia, Universidade de São Paulo, São Paulo, 2006.

JEREZ, J. A.; BRANDÃO, P. E.; BUZINARO, M. G.; GREGORI, F.; ROSALES, C. A. R.; ITO, F. H.; SAKAI, T.. Detecção de rotavírus e coronavírus em fezes de bezerros neonatos com diarréia criados em vários municípios do estado de São Paulo, Brasil. Arqs Inst. Biol., São Paulo, v.69, n.2, p.19-23, 2002.

KAPIL, S.; TRENT, A. M.; GOYAL, S. M.. Excretion and persistence of bovine coronavirus in neonatal calves. Archives of virology, v.115, n.1-2, p. 127-132, 1990.

KRIEG, N. R.; HOLT, J. G... Bergey's Manual of Sistematic Bacteriology. WILLIAMS \& Wilkins, Baltimore, 1986.

KVÁC, M.; KOUBA, M.; VÍTOVEC, J.. Age-related and housing-dependence of Cryptosporidium infection of calves from dairy and beef herds in South Bohemia, Czech Republic. Veterinary Parasitology, v. 137, n.30, p.202-209, 2006.

LAI, M. M. C; PERLMAN, S.; ANDERSON, L. J.. Coronaviridae. In: Fields Virology, $5^{\mathrm{a}}$ ed. Philadephia: Lippincott WILLIAMS \& Wilkins, pp1305-1335, 2007.

LALLO, M. A.. Ocorrência de Cryptosporidium parvum em cães na Grande São Paulo. São Paulo, 1993, 45pp. Dissertação (mestrado). Faculdade de Medicina Veterinária e Zootecnia, Universidade de São Paulo.

LANGONI, H.; LINHARES, A. C.; AVILA, F. A.; DA SILVA, A. V.; ELIAS, A. O.. Contribution to the study of diarrhea etiology in neonate dairy calves in São Paulo state, Brazil. Bras. J. Vet. Res. Anim. Sci., v.41, p.313-319, 2004.

MASTERS, P. S.. The molecular biology of coronaviruses. Advances in Virus Research, v.66, p.193-292, 2006.

MÉDICI, K. C.; STIPP, D. T.; OLIVEIRA, D. B.; FERREIRA, M. C.; BOCADELLO, R. Z.; ALFIERI, A. F.; ALFIERI A. A.. Detection of bovine coronavirus as etiological agent of neonatal diarrhea. Vírus Rev. Res., v.6, p.149-150, 2001.

MOTA, R. A.; SILVA, K. P. C.; RIBEIRO, T. C. F.; RAMOS, G. A. B.; LIMA, E. T.; SILVA, L. B. G.; ZÜNIGA, C. E. A.. Eficácia do Nuflor no tratamento de diarréias em bezerros e leitões. Hora Vet., v.118, p.21-24, 2000. 
MOURA, C.. Caracterização de amostras de Escherichia coli isoladas de bezerros com e sem diarréia: pesquisa de fatores de colonização e toxinas. Dissertação (Mestrado em Biologia) - Faculdade de Biologia, Universidade Estadual de Campinas, Campinas, SP, 2005.

MOXLEY, R. A.; SMITH, D. R.. Attaching-effacing E. coli in cattle. Vet. Clin. North. Am. Food. Anim. Prat., v.26, n.1, p. 29 - 56, 2010.

O'HANDLEY, R. M.. Cryptosporidium parvum infection in cattle: are current perceptions accurate? Trends in Parasitology, v.23, n.10, p.477-480, 2007.

OGASSAWARA, S.; BENASSI, S.. Infeç̧ão experimental de gatos com coração de bovino parasitado por Sarcocystis sp. Sao Paulo. Arq. Inst. Biol., v.47, p.27-32, 1980.

OK, M.; GÜLER, L.; TURGUT, K.; OK, Ü.; SEN, I.; GÜNDÜZ, I.K.; BIRDANE, M. F.; GÜZELBEKTES, H.. The studies on aetiology of diarrhoea in neonatal calves and determination of virulence gene markers of Escherichia coli strains by multiplex PCR. Zoonoses and Public Health, v. 56, p. 94-101, 2009.

OLIVEIRA FILHO, J. P., SILVA, D. P. G.; PACHECO, M. D.; MASCARINI, L. M.; RIBEIRO, M. G.; ALFIERI, A. A.; ALFIERI, A. F.; STIPP, D. T.; BARROS, B. J. P.; BORGES, A. S.. Diarréia em bezerros da raça Nelore criados extensivamente: estudo clínico e etiológico. Pesq. Vet. Bras., v.27, n.10, p.419-424, 2007.

OLSON, M. E.; O'HANDLEY, R. M.; ROLSTON, B. J.; MCALLISTER, T. A.; TOMPSON, R. C. A.. Update on Cryptosporidium and Giardia infections in cattle. Treds. Parasitol., v.20, p.185-191, 2004.

RODRIGUEZ, C. A. R.; BRANDÃO, P. E.; FERREIRA, F.; GREGORI, F.; BUZINARO, M. G.; JEREZ, J. A.. Improved animal rotavirus isolation in MA-104 cells using different trypsin concentrations. Arqs. do Instit. Biol., São Paulo, v. 71, n. 4, p. 437-441, 2004.

SALVADORI, M. R.; VALADARES, G. F.; LEITE, D. S.; BLANCO, J.; YANO, T.. Virulence factors of Escherichia coli isolated from calves with diarrhea in Brazil. Braz. J. Microbiol., v.34, p.230-235, 2003.

SNODGRASS, D. R.; TERZOLO, H. R.; SHERWOOD, D.; CAMPBEL, I.; MENZIES, J. D.; SYNGE, B. A.. Aetiology of diarrhea in young calves. Veterinary Record, V.119, p. 31-34, 1986.

STIPP, D. T.; BARRY, A.; ALFIERI, A. F.; TAKIUCHI, E; T. S.; AMUDE, A. M.; ALFIERI, A. A.. Frequency of BCoV detection by a semi-nested PCR assay in faeces of calves from Brazilian cattle herds. Tropical Anim. Helath Prod., DOI: 10.1007/s11250-009-9347-2, 2009.

TAKIUCHI, E; T. S.; STIPP, D. T.; ALFIERI, A. F.; ALFIERI, A. A.. Improved detection of bovine coronavirus $\mathrm{N}$ gene in faeces of calves infected naturally by a 
semi-nested PCR assay and an internal control. Journal of Virological Methods, v.131, p.148-154, 2006.

VAN REGENMORTEL, M. H. V.; FAUQUET, C. M;. BISHOP, D. H. L;. CARSTENS, E. B;. ESTES, M. K; LEMON, S. M.; MANILOFF, J.; MAYO, M. A.; MACGEOCH, D. J.; PRINGLE, C. R.; WICKNER, R. B.. Virus Taxonomy: The Classification and Nomenclature of Viruses. The Seventh Report of the International Committee on Taxonomy of Viruses. San Diego: Academic Press. 2000. 1167p.

VETTORATO E. D.; FLAIBAN, K. K. M. C.; COSTA, M. C.; BALARIM, M. R. S.; VIDOTTO, O.; LISBÔA, J. A. N.. Concentrações séricas de gamaglobulinas e IgG em bezerros das raças Nelore e Holandesa aos seis mess de vida. In: VIII CONGRESSO BRASILEIRO DE BUIATRIA, VIII, 2009, Minas Gerais. Anais. Ciência Animal Brasileira, supl.1, p.238-243, 2009.

XIAO, L.; HERD, R. P.. Short communication Infection patterns of Cryptosporidium and Giardia in calves. Veterinary Parasitology, v.55, p.257-262, 1994.

WHITE, R. G.; MEBUS, C. A.; TWIEHAUS, M. J.. Incidence of herds infected with a neonatal Calf Diarrhea Virus (NCDV). Veterinary Medicine, Small Animal Clinician, v.65, p.487- 490, 1970. 
APÊNDICES

\begin{tabular}{|c|c|c|c|c|c|c|c|c|c|c|c|c|c|c|c|c|}
\hline \multirow{3}{*}{ Animal } & \multirow{3}{*}{$\begin{array}{l}\text { Idade } \\
\text { (dias) }\end{array}$} & \multirow{3}{*}{ Clínica } & \multirow{3}{*}{ BCoV } & \multirow{3}{*}{$\mathbf{R V}$} & \multicolumn{4}{|c|}{ Coproparasitológico } & \multirow{3}{*}{ Bacteriológico } & \multicolumn{6}{|c|}{ Multiplex } & \multirow{3}{*}{ Obs. } \\
\hline & & & & & \multicolumn{2}{|c|}{ Sacarose } & \multicolumn{2}{|c|}{ H2O-éter } & & \multirow{2}{*}{ Stx1 } & \multirow{2}{*}{ Stx2 } & \multirow{2}{*}{ eae } & \multirow{2}{*}{ K99 } & \multirow{2}{*}{ F41 } & \multirow{2}{*}{ Sta } & \\
\hline & & & & & Qtd. & Parasita & Qtd. & Parasita & & & & & & & & \\
\hline 1843 & 8 & Normal & Neg. & Neg. & 0 & Neg. & 0 & Neg. & $\begin{array}{l}\text { E. coli + Não } \\
\text { fermentadora }\end{array}$ & - & - & - & - & - & - & \\
\hline 1845 & 8 & Normal & Neg. & Neg. & 0 & Neg. & 0 & Neg. & E.coli & - & - & - & - & - & - & \\
\hline 1847 & 8 & Normal & Neg. & Neg. & 0 & Neg. & 0 & Neg. & E.coli & - & - & - & - & - & - & \\
\hline 1855 & 8 & Normal & Neg. & Neg. & 0 & Neg. & 0 & Neg. & E.coli & - & - & - & - & - & - & \\
\hline 1871 & 6 & Normal & Neg. & Neg. & 0 & Neg. & 0 & Neg. & E.coli & - & - & - & - & - & - & \\
\hline 1881 & 3 & Normal & Neg. & Neg. & 0 & Neg. & 0 & Neg. & E.coli & - & - & - & - & - & - & \\
\hline 1882 & 3 & Normal & Neg. & Neg. & 0 & Neg. & 0 & Neg. & E.coli & - & - & - & - & - & - & \\
\hline 1883 & 3 & Normal & Neg. & Neg. & 0 & Neg. & 0 & Neg. & E.coli & - & - & - & - & - & - & \\
\hline 1884 & 3 & Normal & Neg. & Neg. & 0 & Neg. & 0 & Neg. & E.coli & - & - & - & - & - & - & \\
\hline 1886 & 2 & Normal & Neg. & Neg. & 0 & Neg. & 0 & Neg. & E.coli & - & - & - & - & - & - & \\
\hline 1887 & 2 & Normal & Neg. & Neg. & 0 & Neg. & 0 & Neg. & E.coli & - & - & - & - & - & - & \\
\hline 1893 & 1 & Normal & Neg. & Neg. & 0 & Neg. & 0 & Neg. & $\begin{array}{c}\text { E. coli + } \\
\text { Klebsiella } \\
\text { oxytoca }\end{array}$ & - & - & - & - & - & - & \\
\hline 2097 & 6 & Normal & Neg. & Pos. & 0 & Neg. & 0 & Neg. & $\begin{array}{c}\text { E. coli + } \\
\text { Klebsiella } \\
\text { pneumoniae } \\
\text { sbsp. azanae }\end{array}$ & - & - & - & - & - & - & \\
\hline 2098 & NA & NA & NA & NA & NA & NA & NA & NA & NA & - & - & - & - & - & - & Incluído na C2 \\
\hline 2101 & 5 & Normal & Neg. & Pos. & 0 & Neg. & 0 & Neg. & $\begin{array}{c}\text { E. coli }+ \\
\text { Aeromonas } \\
\text { hydrophila }\end{array}$ & - & - & - & - & - & - & \\
\hline 2102 & 5 & Normal & Neg. & Neg. & 0 & Neg. & 0 & Neg. & E. coli & - & - & - & - & - & - & \\
\hline
\end{tabular}

Quadro 9 - Resumo dos resultados obtidos na primeira colheita de amostras na fazenda com casos esporádicos de diarréia (Continua) 


\begin{tabular}{|c|c|c|c|c|c|c|c|c|c|c|c|c|c|c|c|c|}
\hline \multirow{3}{*}{ Animal } & \multirow{3}{*}{$\begin{array}{l}\text { Idade } \\
\text { (dias) }\end{array}$} & \multirow{3}{*}{ Clínica } & \multirow{3}{*}{ BCoV } & \multirow{3}{*}{ RV } & \multicolumn{4}{|c|}{ Coproparasitológico } & \multirow{3}{*}{ Bacteriológico } & \multicolumn{6}{|c|}{ Multiplex } & \multirow{3}{*}{ Obs. } \\
\hline & & & & & \multicolumn{2}{|c|}{ Sacarose } & \multicolumn{2}{|c|}{ H2O-éter } & & \multirow{2}{*}{ Stx1 } & \multirow{2}{*}{ Stx2 } & \multirow{2}{*}{ eae } & \multirow{2}{*}{ K99 } & \multirow{2}{*}{ F41 } & \multirow{2}{*}{ Sta } & \\
\hline & & & & & Qtd. & Parasita & Qtd. & Parasita & & & & & & & & \\
\hline 2103 & 5 & Normal & Neg. & Neg. & 0 & Neg. & 0 & Neg. & E. coli & - & - & - & - & - & - & \\
\hline 2106 & 4 & Normal & Neg. & Neg. & 0 & Neg. & 0 & Neg. & E. coli & - & - & - & - & - & - & \\
\hline 2107 & 4 & Normal & Neg. & Neg. & 0 & Neg. & 0 & Neg. & E. coli & - & - & - & - & - & - & \\
\hline 2108 & 4 & Normal & Neg. & Neg. & 0 & Neg. & 0 & Neg. & E. coli & - & - & - & - & - & - & \\
\hline 2109 & 4 & Normal & Neg. & Neg. & 0 & Neg. & 0 & Neg. & $\begin{array}{c}\text { Klebsiella } \\
\text { pneumoniae } \\
\text { sbsp. azanae }\end{array}$ & - & - & - & - & - & - & \\
\hline 2110 & 1 & Normal & Neg. & Neg. & 0 & Neg. & 0 & Neg. & E. coli & - & - & - & - & - & - & \\
\hline 2111 & 1 & Normal & Neg. & Neg. & 0 & Neg. & 0 & Neg. & E. coli & - & - & - & - & - & - & \\
\hline 2112 & 1 & Normal & Neg. & Neg. & 0 & Neg. & 0 & Neg. & E. coli & - & - & - & - & - & - & \\
\hline 2114 & 1 & Normal & Neg. & Neg. & 0 & Neg. & 0 & Neg. & E. coli & - & - & - & - & - & - & \\
\hline 2115 & 1 & Normal & Neg. & Pos. & 0 & Neg. & 0 & Neg. & E. coli & - & - & - & - & - & - & \\
\hline 2116 & 1 & Normal & Neg. & Neg. & 0 & Neg. & 0 & Neg. & E. coli & - & - & - & - & - & - & \\
\hline $\begin{array}{l}2117 \\
\text { (RN) }\end{array}$ & 1 & Normal & Pos. & Neg. & 0 & Neg. & 0 & Neg. & $\begin{array}{c}\text { Klebsiella } \\
\text { pneumoniae } \\
\text { sbsp. azanae }\end{array}$ & - & - & - & - & - & - & \\
\hline
\end{tabular}

Quadro 9 - Resumo dos resultados obtidos na primeira colheita de amostras na fazenda com casos esporádicos de diarréia. (Conclusão) 


\begin{tabular}{|c|c|c|c|c|c|c|c|c|c|c|c|c|c|c|c|c|c|c|}
\hline \multirow{3}{*}{ Animal } & \multirow{3}{*}{$\begin{array}{l}\text { Idade } \\
\text { (dias) }\end{array}$} & \multirow{3}{*}{ Clínica } & \multirow{3}{*}{ BCoV } & \multirow{3}{*}{ RV } & \multicolumn{4}{|c|}{ Coproparasitológico } & \multirow{2}{*}{\multicolumn{2}{|c|}{$\begin{array}{c}\text { Coproparasiotológico } \\
\text { Final }\end{array}$}} & \multirow{3}{*}{ Bacteriológico } & \multicolumn{6}{|c|}{ Multiplex } & \multirow{3}{*}{ Obs. } \\
\hline & & & & & \multicolumn{2}{|c|}{ Sacarose } & \multicolumn{2}{|c|}{ H2O-éter } & & & & \multirow{2}{*}{ Stx1 } & \multirow{2}{*}{ Stx2 } & \multirow{2}{*}{ eae } & \multirow{2}{*}{ K99 } & \multirow{2}{*}{ F41 } & \multirow{2}{*}{ Sta } & \\
\hline & & & & & Qtd. & Parasita & Qtd. & Parasita & Qtd. & Parasita & & & & & & & & \\
\hline 1843 & 70 & Normal & Neg. & Neg. & + & $\begin{array}{l}\text { Eimeria } \\
\text { spp }\end{array}$ & raros & Eimeria spp & + & Eimeria spp & $\begin{array}{c}\text { E. coli + } \\
\text { Edwarsiella } \\
\text { tarda biogrupo } \\
I\end{array}$ & - & - & + & + & - & - & \\
\hline \multirow{2}{*}{1845} & \multirow{2}{*}{70} & \multirow[b]{2}{*}{ Normal } & \multirow{2}{*}{ Neg. } & \multirow[b]{2}{*}{ Neg. } & \multirow{2}{*}{ raros } & \multirow{2}{*}{$\begin{array}{c}\text { Eimeria } \\
\text { spp }\end{array}$} & raros & Eimeria spp & raros & Eimeria spp & \multirow{2}{*}{$\begin{array}{l}\text { E. coli + Não } \\
\text { fermentadora }\end{array}$} & \multirow{2}{*}{-} & \multirow{2}{*}{ - } & \multirow{2}{*}{ - } & \multirow{2}{*}{ - } & \multirow{2}{*}{ - } & \multirow{2}{*}{-} & \\
\hline & & & & & & & raros & Strongyloidea & raros & Strongyloidea & & & & & & & & \\
\hline 1847 & 70 & Normal & Neg. & Neg. & raros & $\begin{array}{c}\text { Eimeria } \\
\text { spp }\end{array}$ & raros & Eimeria spp & raros & Eimeria spp & E. coli & - & - & - & - & - & - & \\
\hline 1855 & 70 & Normal & Neg. & Neg. & 0 & Neg. & 0 & Neg. & 0 & Neg. & E. coli & - & - & - & - & - & - & $\begin{array}{l}\text { Lavado de } \\
\text { luva, pouco } \\
\text { conteúdo }\end{array}$ \\
\hline 1870 & 68 & Normal & Neg. & Neg. & raros & $\begin{array}{c}\text { Eimeria } \\
\text { spp }\end{array}$ & raros & Eimeria spp & raros & Eimeria spp & $\begin{array}{c}\text { E. coli + Hafnia } \\
\text { alvei }\end{array}$ & - & - & - & - & - & - & \\
\hline 1871 & 68 & Normal & Neg. & Neg. & + & $\begin{array}{l}\text { Eimeria } \\
\text { spp }\end{array}$ & raros & Eimeria spp & + & Eimeria spp & $\begin{array}{c}\text { E. coli }+ \\
\text { Klebisiella } \\
\text { pneumoniae } \\
\text { sbspp azanae }\end{array}$ & - & - & - & - & - & - & \\
\hline 1881 & 65 & Normal & Neg. & Neg. & 0 & Neg. & 0 & Neg. & 0 & Neg. & $\begin{array}{l}\text { E. coli + Não } \\
\text { fermentadora }\end{array}$ & - & - & - & + & - & - & $\begin{array}{l}\text { Lavado de } \\
\text { luva, pouco } \\
\text { conteúdo }\end{array}$ \\
\hline 1882 & 65 & Normal & $\mathrm{Neq}$ & $\mathrm{Neg}$ & raros & Eimeria & 0 & $\mathrm{Neq}$ & raros & Fimeria snn & F coli & - & - & - & + & - & - & $\begin{array}{c}\text { Colônia } 1 \\
\text { E.coli }\end{array}$ \\
\hline 1002 & S & - & Treg. & tveg. & tarus & spp & 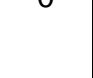 & Treg. & tarus & 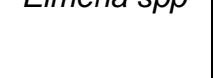 & L. Lon & - & - & + & - & - & - & $\begin{array}{c}\text { Colônia } 2 \\
\text { E.coli }\end{array}$ \\
\hline 1883 & 65 & Normal & Neg. & Neg. & raros & $\begin{array}{l}\text { Eimeria } \\
\text { spp }\end{array}$ & 0 & Neg. & raros & Eimeria spp & E. coli & - & - & - & - & - & - & \\
\hline 1884 & 65 & Diarréia & Pos. & Neg. & ++++ & $\begin{array}{c}\text { Eimeria } \\
\text { spp }\end{array}$ & raros & Eimeria spp & ++++ & Eimeria spp & E. coli & - & - & - & - & - & - & \\
\hline
\end{tabular}

Quadro 10 - Resumo dos resultados obtidos na segunda colheita de amostras na fazenda com casos esporádicos de diarréia (continua) 


\begin{tabular}{|c|c|c|c|c|c|c|c|c|c|c|c|c|c|c|c|c|c|}
\hline \multirow{3}{*}{ Animal } & \multirow{3}{*}{$\begin{array}{l}\text { Idade } \\
\text { (dias) }\end{array}$} & \multirow{3}{*}{ Clínica } & \multirow{3}{*}{$\mathrm{BCoV}$} & \multirow{3}{*}{ RV } & \multicolumn{4}{|c|}{ Coproparasitológico } & \multirow{2}{*}{\multicolumn{2}{|c|}{$\begin{array}{c}\text { Coproparasiotológico } \\
\text { Final }\end{array}$}} & \multirow{3}{*}{ Bacteriológico } & \multicolumn{6}{|c|}{ Multiplex } \\
\hline & & & & & \multicolumn{2}{|c|}{ Sacarose } & \multicolumn{2}{|c|}{ H2O-éter } & & & & \multirow{2}{*}{ Stx1 } & \multirow{2}{*}{ Stx2 } & \multirow{2}{*}{ eae } & \multirow{2}{*}{ K99 } & \multirow{2}{*}{ F41 } & \multirow{2}{*}{ Sta } \\
\hline & & & & & Qtd. & Parasita & Qtd. & Parasita & Qtd. & Parasita & & & & & & & \\
\hline 1886 & 64 & Normal & Neg. & Neg. & raros & Eimeria spp & raros & Eimeria spp & raros & Eimeria $s p p$ & E. coli & & - & - & & - & \\
\hline 1887 & 64 & Normal & Neg. & Neg. & raros & Eimeria spp & raros & Eimeria spp & raros & Eimeria spp & E. coli & & - & - & - & - & \\
\hline 1892 & 63 & Normal & Neg. & Neg. & 0 & Neg. & 0 & Neg. & 0 & Neg. & E. coli & - & - & - & - & - & - \\
\hline 1893 & 63 & Normal & Neg. & Neg. & raros & Eimeria spp & raros & Eimeria spp & raros & Eimeria spp & E. coli & - & - & - & - & - & - \\
\hline 2097 & 58 & Normal & Neg. & Neg. & raros & Eimeria spp & raros & Eimeria spp & raros & Eimeria spp & $\begin{array}{c}\text { E. coli + } \\
\text { Klebisiella } \\
\text { pneumoniae } \\
\text { sbspp azanae }\end{array}$ & - & - & - & - & - & \\
\hline 2098 & 58 & Diarréia & Neg. & Pos. & raros & Eimeria spp & raros & Eimeria spp & raros & Eimeria spp & E. coli & & - & - & - & - & \\
\hline \multirow{2}{*}{2101} & \multirow{2}{*}{59} & \multirow{2}{*}{ Normal } & \multirow{2}{*}{ Neg. } & \multirow{2}{*}{ Neg. } & raros & Eimeria spp & raros & Eimeria spp & raros & Eimeria spp & \multirow{2}{*}{ E. coli } & \multirow{2}{*}{ - } & \multirow{2}{*}{ - } & \multirow{2}{*}{ - } & \multirow{2}{*}{ - } & & \\
\hline & & & & & raros & Strongyloidea & raros & Strongyloidea & raros & Strongyloidea & & & & & & & \\
\hline \multirow{2}{*}{2102} & \multirow{2}{*}{59} & \multirow{2}{*}{ Normal } & & & raros & Eimeria spp & raros & Eimeria spp & raros & Eimeria spp & & & & & & & \\
\hline & & & & & raros & Strongyloidea & raros & Strongyloidea & raros & Strongyloidea & & & & & & & \\
\hline & & & & & raros & Eimeria spp & & & raros & Eimeria spp & & & & & & & \\
\hline 2103 & 59 & Normal & iveg. & iveg. & raros & Strongyloidea & & Trey. & raros & Strongyloidea & & & 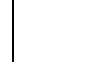 & & & 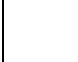 & \\
\hline 2106 & 60 & Normal & Neg. & Neg. & raros & Eimeria spp & raros & Eimeria spp & raros & Eimeria spp & E. coli & - & - & - & - & - & - \\
\hline 2107 & 60 & Normal & Neg. & Neg. & raros & Eimeria spp & raros & Eimeria spp & raros & Eimeria spp & E. coli & - & - & - & - & - & - \\
\hline
\end{tabular}

Quadro 10 - Resumo dos resultados obtidos na segunda colheita de amostras na fazenda com casos esporádicos de diarréia (continua) 


\begin{tabular}{|c|c|c|c|c|c|c|c|c|c|c|c|c|c|c|c|c|c|}
\hline \multirow{3}{*}{ Animal } & \multirow{3}{*}{$\begin{array}{l}\text { Idade } \\
\text { (dias) }\end{array}$} & \multirow{3}{*}{ Clínica } & \multirow{3}{*}{ BCoV } & \multirow{3}{*}{$\mathbf{R V}$} & \multicolumn{4}{|c|}{ Coproparasitológico } & \multirow{2}{*}{\multicolumn{2}{|c|}{$\begin{array}{c}\text { Coproparasiotológico } \\
\text { Final }\end{array}$}} & \multirow{3}{*}{ Bacteriológico } & \multicolumn{6}{|c|}{ Multiplex } \\
\hline & & & & & \multicolumn{2}{|r|}{ Sacarose } & \multicolumn{2}{|c|}{ H2O-éter } & & & & \multirow{2}{*}{ Stx1 } & \multirow{2}{*}{ Stx2 } & \multirow{2}{*}{ eae } & \multirow{2}{*}{ K99 } & \multirow{2}{*}{ F41 } & \multirow{2}{*}{ Sta } \\
\hline & & & & & Qtd. & Parasita & Qtd. & Parasita & Qtd. & Parasita & & & & & & & \\
\hline 2108 & 60 & Normal & Neg. & Neg. & raros & Eimeria spp & 0 & Neg. & raros & Eimeria spp & E. coli & - & - & - & - & - & - \\
\hline 2109 & 60 & Normal & Neg. & Neg. & raros & Eimeria spp & 0 & Neg. & raros & Eimeria spp & $\begin{array}{c}\text { E. coli + } \\
\text { Klebisiella } \\
\text { pneumoniae } \\
\text { sbspp azanae }\end{array}$ & - & - & - & - & - & - \\
\hline 2110 & 63 & Normal & Neg. & Neg. & + & Eimeria spp & raros & Eimeria spp & + & Eimeria spp & E. coli & - & - & - & - & - & - \\
\hline 2111 & 63 & Normal & Neg. & Neg. & raros & Eimeria spp & raros & Eimeria spp & raros & Eimeria spp & E. coli & + & - & - & - & - & - \\
\hline \multirow{2}{*}{2112} & \multirow{2}{*}{63} & \multirow{2}{*}{ Normal } & \multirow{2}{*}{ Pos. } & \multirow{2}{*}{ Neg. } & raros & Eimeria spp & raros & Eimeria spp & raros & Eimeria spp & \multirow{2}{*}{ E. coli } & \multirow{2}{*}{-} & \multirow{2}{*}{-} & \multirow{2}{*}{-} & \multirow{2}{*}{-} & \multirow{2}{*}{-} & \multirow{2}{*}{-} \\
\hline & & & & & raros & Strongyloidea & raros & Strongyloidea & raros & Strongyloidea & & & & & & & \\
\hline 2114 & 63 & Normal & Neg. & Neg. & raros & Eimeria spp & raros & Eimeria spp & raros & Eimeria spp & E. coli & - & - & - & - & - & - \\
\hline \multirow{2}{*}{2115} & \multirow{2}{*}{63} & \multirow{2}{*}{ Normal } & \multirow{2}{*}{ Neg. } & & raros & Eimeria spp & & & raros & Eimeria spp & & & & & & & \\
\hline & & & & They. & raros & Strongyloidea & tintos & Litictic opp & raros & Strongyloidea & ㄴ. & & & ( & & & \\
\hline 2116 & 63 & Normal & Neg. & Neg. & raros & Eimeria spp & raros & Eimeria spp & raros & Eimeria spp & E. coli & - & - & - & - & - & - \\
\hline & & & & & & & raros & Eimeria $s p p$ & & & E. coli + & & & & & & \\
\hline 2117 & 63 & Normal & Neg. & Neg. & + & Eimeria spp & raros & Strongyloidea & + & Eimeria spp & $\begin{array}{c}\text { Klebisiella } \\
\text { pneumoniae } \\
\text { sbspp azanae }\end{array}$ & - & - & - & - & - & - \\
\hline
\end{tabular}

Quadro 10 - Resumo dos resultados obtidos na segunda colheita de amostras na fazenda com casos esporádicos de diarréia (conclusão) 


\begin{tabular}{|c|c|c|c|c|c|c|c|c|c|c|c|c|c|c|c|c|c|}
\hline \multirow{3}{*}{ Animal } & \multirow{3}{*}{$\begin{array}{l}\text { Idade } \\
\text { (dias) }\end{array}$} & \multirow{3}{*}{ Clínica } & \multirow{3}{*}{ BCoV } & \multirow{3}{*}{ RV } & \multicolumn{4}{|c|}{ Coproparasitológico } & \multirow{2}{*}{\multicolumn{2}{|c|}{$\begin{array}{c}\text { Coproparasiotológico } \\
\text { Final }\end{array}$}} & \multirow{3}{*}{ Bacteriológico } & \multicolumn{6}{|c|}{ Multiplex } \\
\hline & & & & & \multicolumn{2}{|r|}{ Sacarose } & \multicolumn{2}{|c|}{ H2O-éter } & & & & \multirow{2}{*}{ Stx1 } & \multirow{2}{*}{ Stx2 } & \multirow{2}{*}{ eae } & \multirow{2}{*}{ K99 } & \multirow{2}{*}{ F41 } & \multirow{2}{*}{ Sta } \\
\hline & & & & & Qtd. & Parasita & Qtd. & Parasita & Qtd. & Parasita & & & & & & & \\
\hline 1843 & 92 & Normal & Neg. & Neg. & raros & Eimeria spp & 0 & Neg. & raros & Eimeria spp & E. coli & - & - & - & - & - & - \\
\hline 1845 & 92 & Normal & Neg. & Neg. & raros & Strongyloidea & 0 & Neg. & raros & Strongyloidea & E. coli & - & - & - & - & - & 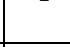 \\
\hline 1847 & 92 & Normal & Neg. & Neg. & raros & Eimeria spp & raros & Eimeria spp & raros & Eimeria spp & E. coli & - & - & - & - & - & - \\
\hline & & & & & & & raros & Eimeria spp & raros & Eimeria spp & 5 ondi & 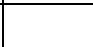 & 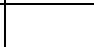 & 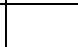 & & 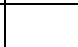 & \\
\hline 1871 & 90 & Normal & $\mathrm{Neq}$ & $\mathrm{Neq}$ & raros & Fimeria snn & raros & Eimeria spp & raros & Eimeria spp & F coli & 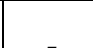 & 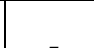 & 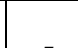 & 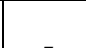 & 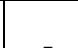 & \\
\hline $18 / 1$ & 90 & INormal & Neg. & Neg. & raros & EImenta spp & raros & Strongyloidea & raros & Strongyloidea & ㄷ. COII & - & - & - & - & - & - \\
\hline 1881 & 87 & Normal & Neg. & Neg. & raros & Eimeria spp & 0 & Neg. & raros & Eimeria spp & $\begin{array}{c}\text { E. coli + } \\
\text { Klebsiella } \\
\text { oxytoca }\end{array}$ & + & - & - & - & - & - \\
\hline 1882 & 87 & Normal & Neg. & Neg. & raros & Eimeria spp & raros & Eimeria spp & raros & Eimeria spp & $\begin{array}{c}\text { E. coli + } \\
\text { Shigella sppp }\end{array}$ & - & - & - & - & - & - \\
\hline 2101 & 88 & Normal & Neg. & Pos. & raros & Eimeria spp & raros & Eimeria spp & raros & Eimeria spp & $\begin{array}{l}\text { E. coli + } \\
\text { Citrobacter } \\
\quad \text { freudii }\end{array}$ & - & - & + & - & - & - \\
\hline 2102 & 88 & Normal & Neg. & Neg. & 0 & Neg. & 0 & Neg. & 0 & Neg. & E. coli & - & - & - & - & - & - \\
\hline
\end{tabular}

Quadro 11 - Resumo dos resultados obtidos na terceira colheita de amostras na fazenda com casos esporádicos de diarréia (continua) 


\begin{tabular}{|c|c|c|c|c|c|c|c|c|c|c|c|c|c|c|c|c|c|}
\hline \multirow{3}{*}{ Animal } & \multirow{3}{*}{$\begin{array}{l}\text { Idade } \\
\text { (dias) }\end{array}$} & \multirow{3}{*}{ Clínica } & \multirow{3}{*}{ BCoV } & \multirow{3}{*}{ RV } & \multicolumn{4}{|c|}{ Coproparasitológico } & \multirow{2}{*}{\multicolumn{2}{|c|}{$\begin{array}{c}\text { Coproparasiotológico } \\
\text { Final }\end{array}$}} & \multirow{3}{*}{ Bacteriológico } & \multicolumn{6}{|c|}{ Multiplex } \\
\hline & & & & & \multicolumn{2}{|r|}{ Sacarose } & \multicolumn{2}{|r|}{ H2O-éter } & & & & \multirow{2}{*}{ Stx 1} & \multirow{2}{*}{ Stx2 } & \multirow{2}{*}{ eae } & \multirow{2}{*}{ K99 } & \multirow{2}{*}{ F41 } & \multirow{2}{*}{ Sta } \\
\hline & & & & & Qtd. & Parasita & Qtd. & Parasita & Qtd. & Parasita & & & & & & & \\
\hline 2103 & 88 & Normal & Neg. & Neg. & raros & Eimeria spp & raros & Eimeria spp & raros & Eimeria spp & E. coli & - & & - & - & & - \\
\hline 2106 & 89 & Normal & Neg. & Neg. & raros & Eimeria spp & raros & Eimeria spp & raros & Eimeria spp & $\begin{array}{c}\text { E. coli + } \\
\text { Citrobacter } \\
\text { diversus }\end{array}$ & - & & - & - & - & - \\
\hline 2107 & 89 & Normal & Neg. & Neg. & raros & Eimeria spp & 0 & Neg. & raros & Eimeria spp & E. coli & - & - & - & - & - & - \\
\hline 2108 & 89 & Normal & Neg. & Neg. & raros & Eimeria spp & raros & Eimeria spp & raros & Eimeria spp & E. coli & - & - & - & - & - & - \\
\hline 2109 & 89 & Normal & Neg. & Neg. & raros & Eimeria spp & 0 & Neg. & raros & Eimeria spp & $\begin{array}{c}\text { E. colit } \\
\text { Edwasiella } \\
\text { tarda biogrupo } \\
I\end{array}$ & - & - & - & - & - & - \\
\hline 2110 & 91 & Normal & Neg. & Neg. & 0 & Neg. & 0 & Neg. & 0 & Neg. & Salmonella spp & NA & NA & NA & NA & NA & NA \\
\hline 2111 & 91 & Normal & Neg. & Neg. & 0 & Neg. & raros & Eimeria spp & raros & Eimeria spp & E. coli & - & - & - & - & - & - \\
\hline \multirow{2}{*}{2112} & \multirow{2}{*}{91} & \multirow{2}{*}{ Normal } & \multirow{2}{*}{ Neg. } & \multirow{2}{*}{ Neg. } & raros & Eimeria spp & raros & Eimeria spp & raros & Eimeria spp & \multirow{2}{*}{ E. coli } & \multirow{2}{*}{+} & \multirow{2}{*}{-} & \multirow{2}{*}{+} & \multirow{2}{*}{-} & \multirow{2}{*}{-} & \multirow{2}{*}{-} \\
\hline & & & & & raros & Strongyloidea & raros & Strongyloidea & raros & Strongyloidea & & & & & & & \\
\hline 2114 & 91 & Normal & Neg. & Neg. & 0 & Neg. & 0 & Neg. & 0 & Neg. & E. coli & - & - & - & - & - & - \\
\hline 2115 & 91 & Normal & Neg. & Neg. & 0 & Neg. & 0 & Neg. & 0 & Neg. & E. coli & + & - & + & - & - & - \\
\hline 2116 & 91 & Normal & Neg. & Neg. & raros & Eimeria spp & raros & Eimeria spp & raros & Eimeria spp & E. coli & - & & - & - & - & \\
\hline 2117 & 91 & Normal & Neg. & Neg. & raros & Eimeria spp & raros & Eimeria spp & raros & Eimeria spp & $\begin{array}{c}\text { E. coli }+ \\
\text { Shigella sppp }\end{array}$ & - & & - & & & \\
\hline
\end{tabular}

Quadro 11 - Resumo dos resultados obtidos na terceira colheita de amostras na fazenda com casos esporádicos de diarréia (conclusão) 


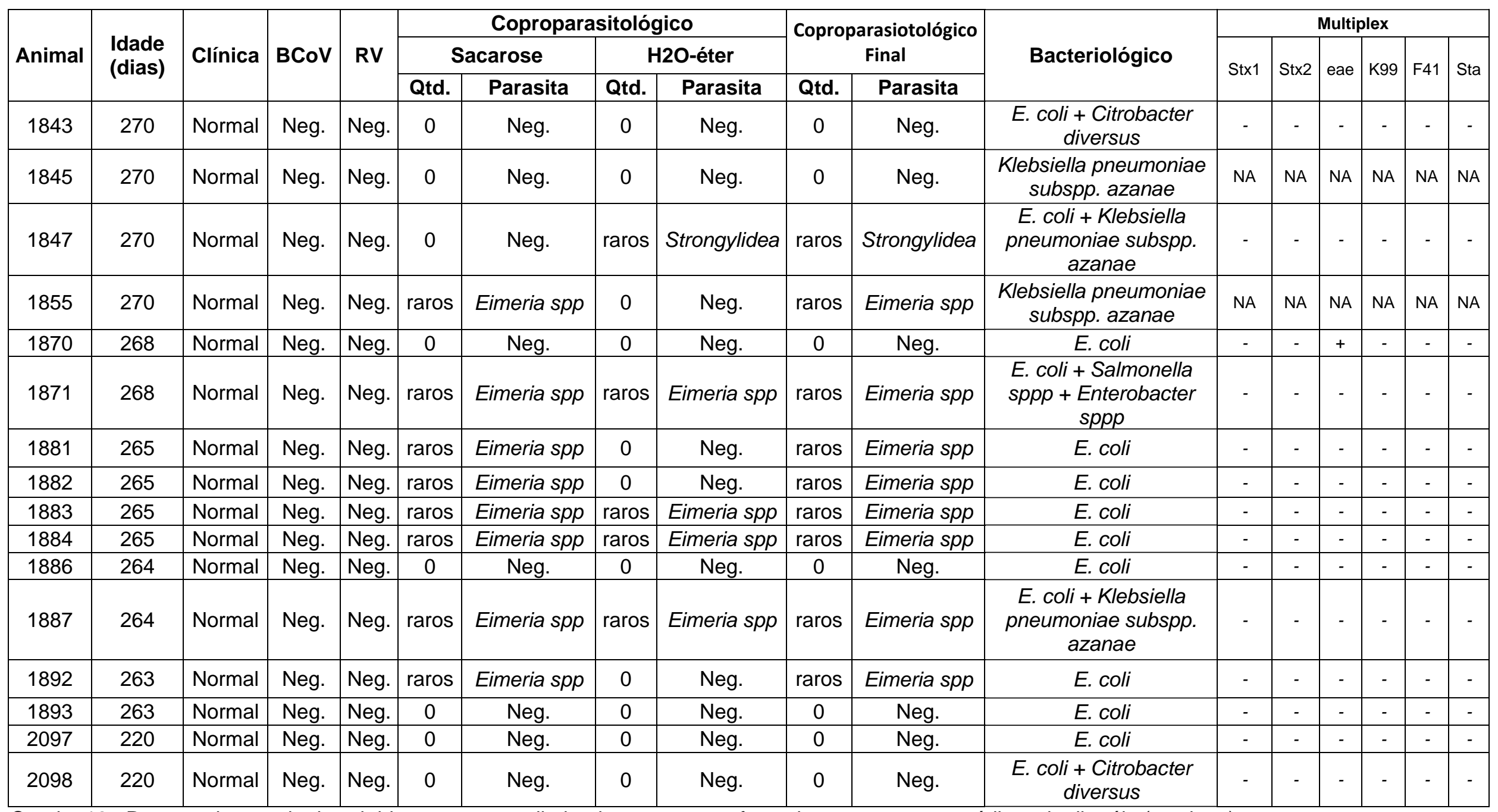

Quadro 12 - Resumo dos resultados obtidos na quarta colheita de amostras na fazenda com casos esporádicos de diarréia (continua) 


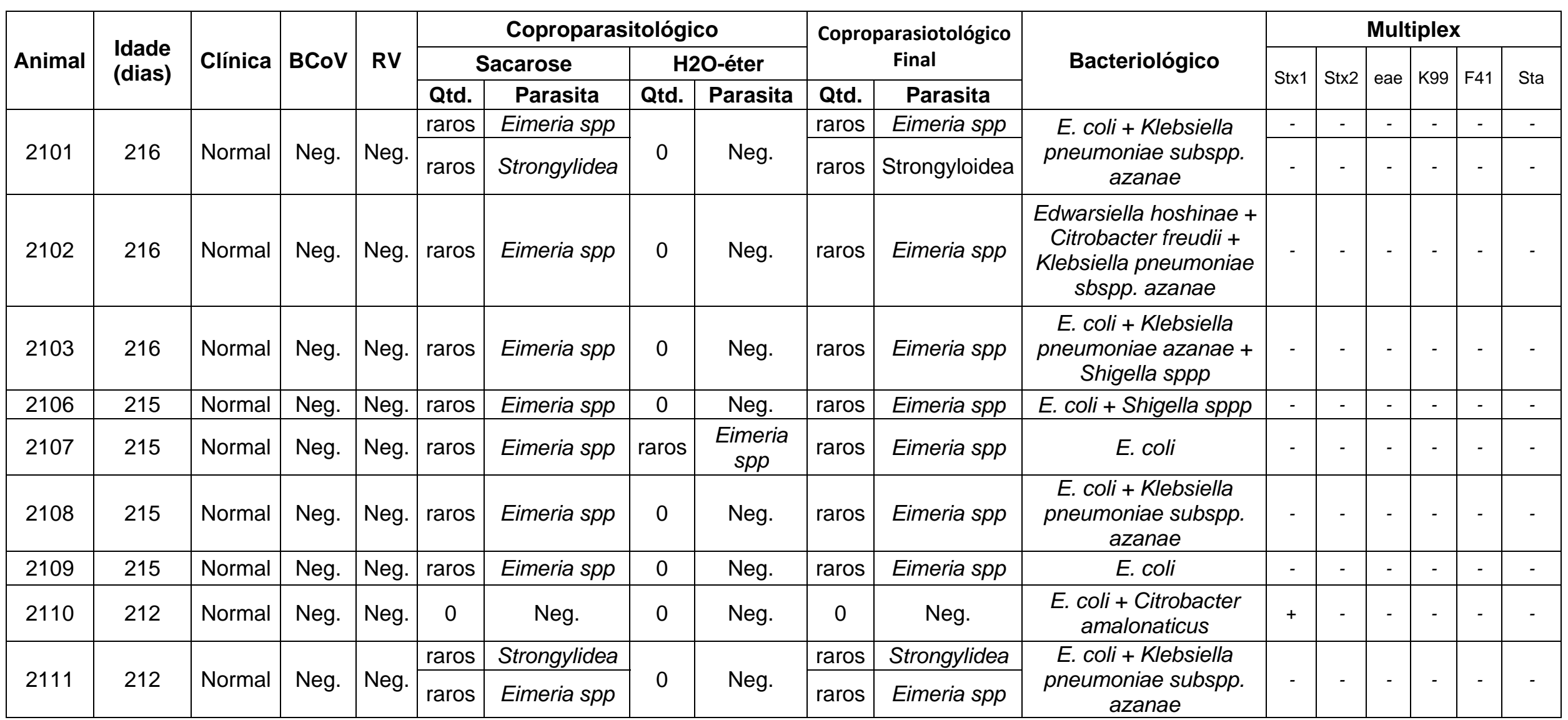

Quadro 12 - Resumo dos resultados obtidos na quarta colheita de amostras na fazenda com casos esporádicos de diarréia (continua) 


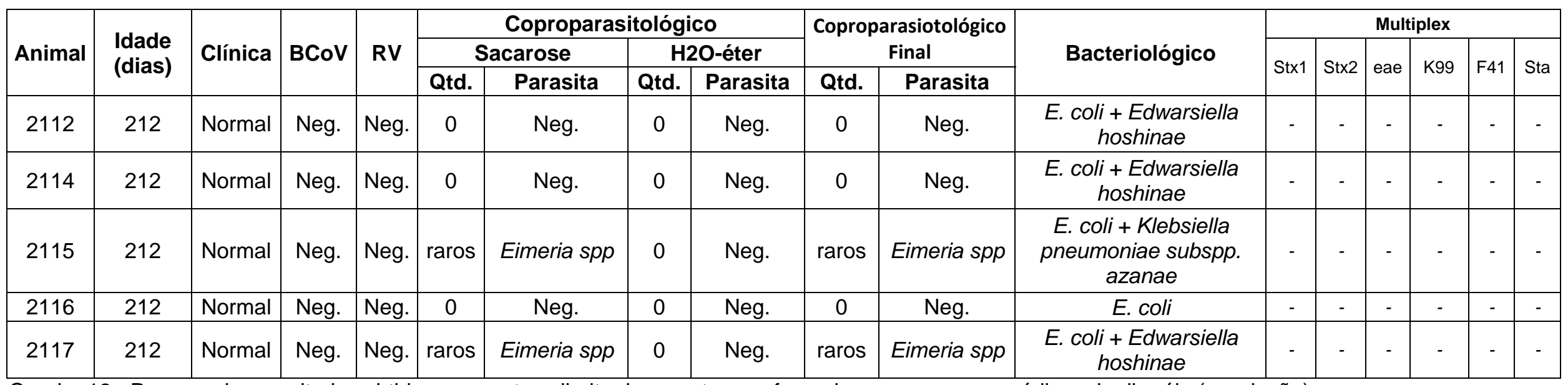

Quadro 12 - Resumo dos resultados obtidos na quarta colheita de amostras na fazenda com casos esporádicos de diarréia (conclusão) 


\begin{tabular}{|c|c|c|c|c|c|c|c|c|c|c|c|c|c|c|c|c|c|c|c|}
\hline \multicolumn{2}{|c|}{ Animal } & \multirow{3}{*}{$\begin{array}{l}\text { Idade } \\
\text { (dias) }\end{array}$} & \multirow{3}{*}{ Clínica } & \multirow{3}{*}{ BCoV } & \multirow{3}{*}{ RV } & \multicolumn{4}{|c|}{ Coproparasitológico } & \multirow{2}{*}{\multicolumn{2}{|c|}{$\begin{array}{c}\text { Coproparasiotológico } \\
\text { Final }\end{array}$}} & \multirow{3}{*}{ Bacteriológico } & \multicolumn{6}{|c|}{ Multiplex } & \multirow{3}{*}{ Obs. } \\
\hline \multirow{2}{*}{$\begin{array}{l}\text { Núm. } \\
\text { Exp. }\end{array}$} & \multirow{2}{*}{$\begin{array}{l}\text { Nome } \\
\text { Eldorado }\end{array}$} & & & & & \multicolumn{2}{|c|}{ Sacarose } & \multicolumn{2}{|c|}{ H2ONeg.éter } & & & & \multirow{2}{*}{ Stx 1} & \multirow{2}{*}{ St×2 } & \multirow{2}{*}{ eae } & \multirow{2}{*}{ K99 } & \multirow{2}{*}{$F 41$} & \multirow{2}{*}{ Sta } & \\
\hline & & & & & & Qtd. & Parasita & Qtd. & Parasita & Qtd. & Parasita & & & & & & & & \\
\hline 1 & Brincado & 10 & Normal & Neg. & Neg. & raros & Eimeria $s p p$ & raros & Eimeria $s p p$ & raros & Eimeria $s p p$ & E. coli & - & & - & - & - & - & \\
\hline 2 & Brincado & 7 & Normal & Neg. & Neg. & raros & Eimeria spp & raros & Eimeria $s p p$ & raros & Eimeria $s p p$ & E. coli & - & - & - & - & - & - & \\
\hline \multirow{2}{*}{3} & \multirow{2}{*}{ Brincado } & \multirow{2}{*}{30} & \multirow{2}{*}{ Normal } & \multirow{2}{*}{ Neg. } & \multirow{2}{*}{ Neg. } & raros & Eimeria spp & \multirow{2}{*}{0} & \multirow{2}{*}{ Neg. } & raros & Eimeria spp & 5 coli & & 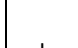 & 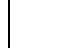 & 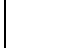 & & & \\
\hline & & & & & & raros & Strongyloidea & & & raros & Strongyloidea & E. coil & & + & - & - & - & - & \\
\hline 4 & Brincado & 60 & Normal & Neg. & Neg. & raros & Eimeria spp & raros & Eimeria spp & raros & Eimeria $s p p$ & E. coli & - & - & - & - & - & - & \\
\hline 5 & Brincado & 5 & Diarréia & Neg. & Neg. & 0 & Neg. & 0 & Neg. & 0 & Neg. & E. coli & - & - & - & - & - & - & \\
\hline 6 & Brincado & 30 & Normal & Neg. & Neg. & raros & Eimeria $s p p$ & raros & Eimeria $s p p$ & raros & Eimeria $s p p$ & E. coli & + & - & - & - & - & - & \\
\hline 7 & Brincado & 45 & Normal & Neq. & Neg. & raros & Eimeria spp & raros & Eimeria spp & raros & Eimeria spp & E coli & - & - & - & - & - & - & \\
\hline & & & & & & & 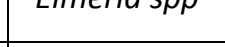 & raros & Strongyloidea & raros & Strongyloidea & L. con & 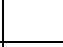 & 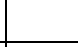 & 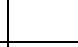 & 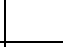 & 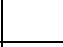 & 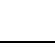 & \\
\hline 8 & Brincado & 60 & Normal & $\mathrm{Neg}$ & $\mathrm{Neg}$ & raros & Fimeria spo & raros & Eimeria spp & raros & Eimeria spp & E coli & - & - & - & - & - & & \\
\hline & Dimicauv & & & & iveg. & & етпетис spp & raros & Strongyloidea & raros & Strongyloidea & E. coll & - & - & - & - & - & - & \\
\hline 9 & Brincado & 30 & Normal & Neg & $\mathrm{Neg}$ & raros & Fimeria snn & raros & Eimeria spp & raros & Eimeria spp & F coli & \pm & & \pm & & & & 2 colônias \\
\hline$y$ & Brimidauo & 30 & Ivormal & Tveg. & Tveg. & raros & EImeria spp & raros & Strongyloidea & raros & Strongyloidea & E. coil & + & - & + & - & - & & $\begin{array}{l}\text { alrerentes } \\
\text { de E. coli }\end{array}$ \\
\hline & & & & & & & & raros & Eimeria spp & raros & Eimeria spp & & & & & & & & $\begin{array}{c}\text { Pouco } \\
\text { conteúdo }\end{array}$ \\
\hline 10 & Brincado & 60 & Normal & Neg. & Neg. & 0 & Neg. & raros & Strongyloidea & raros & Strongyloidea & E. coli & - & + & - & - & - & - & $\begin{array}{l}5 \mathrm{~mL} \mathrm{H} 2 \mathrm{O} \\
\text { DEPC }\end{array}$ \\
\hline 11 & Brincado & 45 & Normal & Neg. & Pos. & raros & Eimeria spp & raros & Eimeria spp & raros & Eimeria spp & E. coli & - & - & - & - & - & - & $\begin{array}{c}\text { Pouco } \\
\text { conteúdo } \\
5 \mathrm{~mL} \mathrm{H2O} \\
\text { DEPC }\end{array}$ \\
\hline 12 & Brincado & 30 & Normal & Neg. & Pos. & raros & Eimeria spp & raros & Eimeria $s p p$ & raros & Eimeria $s p p$ & E. coli & - & - & - & - & - & - & \\
\hline 13 & Brincado & 30 & Diarréia & Neg. & Neg. & 0 & Neg. & 0 & Neg. & 0 & Neg. & E. coli & - & - & - & - & - & - & $\begin{array}{c}\text { Pouco } \\
\text { conteúdo } \\
7 \mathrm{~mL} \text { H2O } \\
\text { DEPC }\end{array}$ \\
\hline & & & & & & raros & Eimeria spp & & & raros & Eimeria $s p p$ & & & & & & & & \\
\hline $1+$ & Dimano & 80 & (Nemina & Nege & iveg. & raros & Strongyloidea & ratos & Litic & raros & Strongyloidea & & & & & & & & \\
\hline
\end{tabular}

Quadro 13 - Resumo dos resultados obtidos na primeira colheita de amostras na fazenda com casos recorrentes de diarréia (continua) 


\begin{tabular}{|c|c|c|c|c|c|c|c|c|c|c|c|c|c|c|c|c|c|c|c|}
\hline \multicolumn{2}{|c|}{ Animal } & \multirow{2}{*}{$\begin{array}{l}\text { Idade } \\
\text { (dias) }\end{array}$} & \multirow[b]{2}{*}{ Clínica } & \multirow[b]{2}{*}{$\mathrm{BCoV}$} & \multirow[b]{2}{*}{ RV } & \multicolumn{4}{|c|}{ Coproparasitológico } & \multirow{2}{*}{\multicolumn{2}{|c|}{$\begin{array}{c}\text { Coproparasiotológico } \\
\text { Final }\end{array}$}} & \multirow[b]{2}{*}{ Bacteriológico } & \multicolumn{6}{|c|}{ Multiplex } & \multirow[b]{2}{*}{ Obs. } \\
\hline Núm. & Nome & & & & & \multicolumn{2}{|c|}{ Sacarose } & \multicolumn{2}{|c|}{ H2ONeg.éter } & & & & $c+2$ & $\mathrm{a}+\mathrm{z}$ & L & Ko & 501 & $c+$ & \\
\hline \multirow{2}{*}{15} & \multirow{2}{*}{ Brincado } & \multirow{2}{*}{60} & \multirow{2}{*}{ Normal } & \multirow{2}{*}{ Neg. } & \multirow{2}{*}{ Neg. } & \multirow{2}{*}{0} & \multirow{2}{*}{ Neg. } & raros & Eimeria spp & raros & Eimeria spp & \multirow{2}{*}{ E. coli } & \multirow{2}{*}{ - } & \multirow{2}{*}{-} & \multirow{2}{*}{ - } & \multirow{2}{*}{ - } & \multirow{2}{*}{ - } & \multirow{2}{*}{ - } & \\
\hline & & & & & & & & raros & Strongyloidea & raros & Strongyloidea & & & & & & & & \\
\hline 16 & Brincado & 30 & Normal & Neg. & Neg. & raros & $\begin{array}{l}\text { Eimeria } \\
\text { spp }\end{array}$ & raros & Eimeria $s p p$ & raros & Eimeria spp & $\begin{array}{c}\text { E. coli }+ \\
\text { Citrobacter } \\
\text { diversus }+ \\
\text { Aeromonas } \\
\text { hydrophila } \\
\end{array}$ & - & - & - & - & - & - & \\
\hline 17 & Brincado & 30 & Diarréia & Neg. & Pos. & 0 & Neg. & 0 & Neg. & 0 & Neg. & $\begin{array}{c}\text { E. coli }+ \\
\text { Citrobacter } \\
\text { diversus }\end{array}$ & - & + & - & - & - & - & \\
\hline 18 & Brincado & 7 & Normal & Neg. & Neg. & 0 & Neg. & 0 & Neg. & 0 & Neg. & $\begin{array}{c}\text { E. coli }+ \\
\text { Edwarsiella } \\
\text { tarda biogrupo } \\
\text { I+ Citrobacter } \\
\text { diversus }+ \\
\text { Providencia } \\
\text { spp } \\
\end{array}$ & + & - & - & - & - & - & $\begin{array}{l}\text { Pouco } \\
\text { conteúdo } \\
7 \mathrm{~mL} \text { DEPC } \\
\text { / Com } \\
\text { diarréia }\end{array}$ \\
\hline 19 & Brincado & 10 & Normal & Neg. & Neg. & 0 & Neg. & 0 & Neg. & 0 & Neg. & $\begin{array}{c}\text { E. coli }+ \\
\text { Serratia spp }+ \\
\text { Klebsiella } \\
\text { pneumoniae } \\
\text { subesp. azanae }\end{array}$ & - & - & - & - & - & - & \\
\hline 20 & $\begin{array}{c}07 \mathrm{sem} \\
\text { brinco }\end{array}$ & 20 & Diarréia & Neg. & Neg. & 0 & Neg. & 0 & Neg. & 0 & Neg. & $\begin{array}{c}\text { E. coli }+ \\
\text { Klebsiella } \\
\text { oxytoca }\end{array}$ & + & - & + & - & - & - & $\begin{array}{c}\text { Com } \\
\text { diarréia }\end{array}$ \\
\hline 21 & $\begin{array}{c}\text { Adotado } \\
160\end{array}$ & 3 & Normal & Neg. & Neg. & 0 & Neg. & 0 & Neg. & 0 & Neg. & E. coli & - & + & - & - & - & - & \\
\hline
\end{tabular}

Quadro 13 - Resumo dos resultados obtidos na primeira colheita de amostras na fazenda com casos recorrentes de diarréia (continua) 


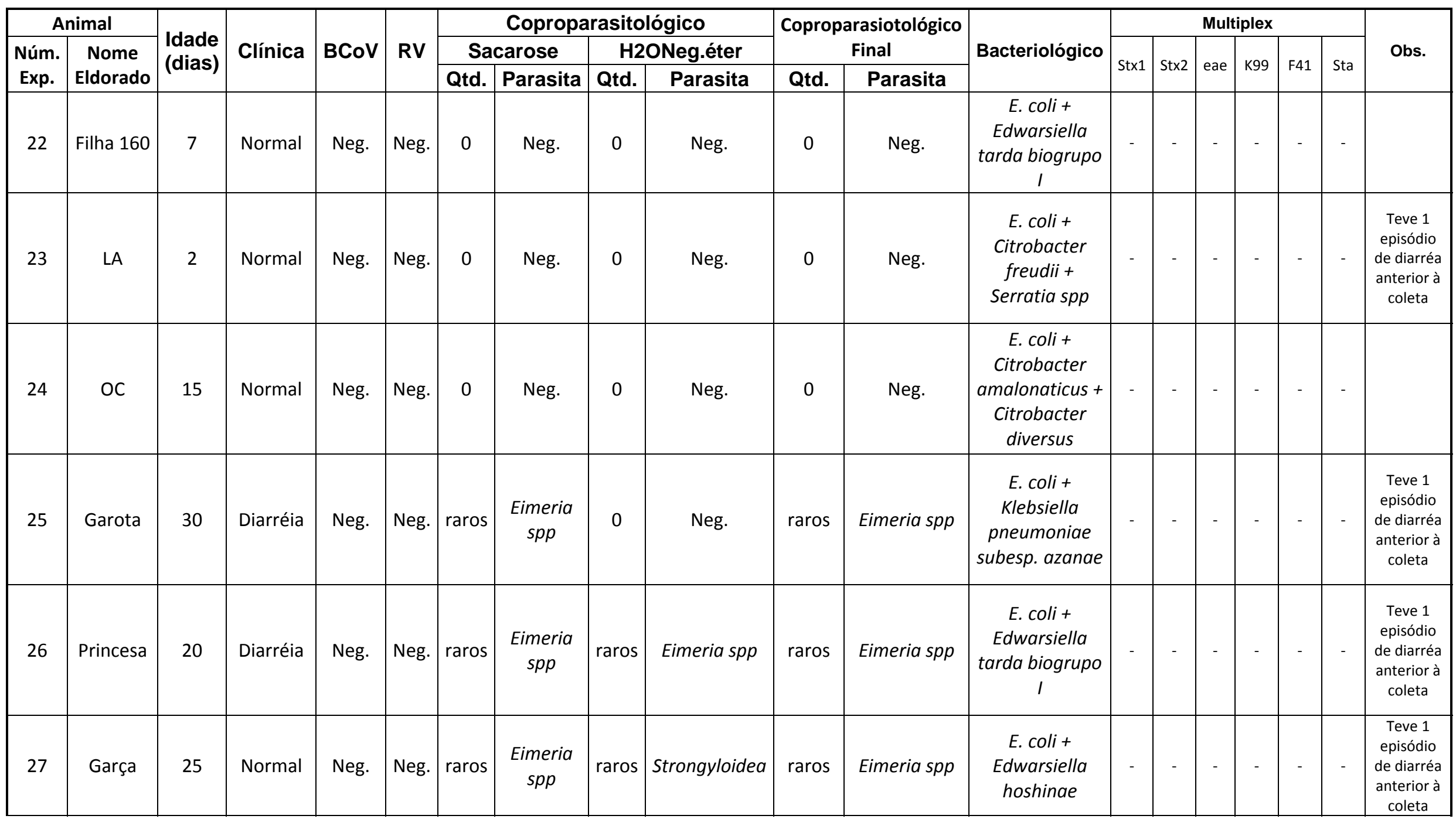

Quadro 14 - Resumo dos resultados obtidos na primeira colheita de amostras na fazenda com casos recorrentes de diarréia (continua) 


\begin{tabular}{|c|c|c|c|c|c|c|c|c|c|c|c|c|c|c|c|c|c|c|c|}
\hline \multicolumn{2}{|c|}{ Animal } & \multirow{3}{*}{$\begin{array}{l}\text { Idade } \\
\text { (dias) }\end{array}$} & \multirow{3}{*}{ Clínica } & \multirow{3}{*}{$\mathrm{BCoV}$} & \multirow{3}{*}{ RV } & \multicolumn{4}{|c|}{ Coproparasitológico } & \multirow{2}{*}{\multicolumn{2}{|c|}{$\begin{array}{c}\text { Coproparasiotológico } \\
\text { Final }\end{array}$}} & \multirow{3}{*}{ Bacteriológico } & \multicolumn{6}{|c|}{ Multiplex } & \multirow{3}{*}{ Obs. } \\
\hline Núm. & Nome & & & & & \multicolumn{2}{|c|}{ Sacarose } & \multicolumn{2}{|c|}{ H2ONeg.éter } & & & & & & & & & & \\
\hline Exp. & Eldorado & & & & & Qtd. & Parasita & Qtd. & Parasita & Qtd. & Parasita & & stxi & Stx2 & eae & K99 & $F 41$ & Sta & \\
\hline 28 & Pintura & 15 & Normal & Neg. & Neg. & raros & $\begin{array}{c}\text { Eimeria } \\
\text { spp }\end{array}$ & raros & $\begin{array}{c}\text { Eimeria } \\
\text { spp }\end{array}$ & raros & Eimeria spp & E. coli & - & - & - & - & - & - & \\
\hline 29 & Mansinha & 5 & Normal & Pos. & Neg. & + & $\begin{array}{c}\text { Eimeria } \\
\text { spp }\end{array}$ & raros & $\begin{array}{c}\text { Eimeria } \\
\text { spp }\end{array}$ & + & Eimeria spp & E. coli & - & - & - & - & - & - & \\
\hline 30 & $\begin{array}{l}\text { Gêmea } \\
\text { Escura }\end{array}$ & 60 & Normal & Neg. & Neg. & 0 & Neg. & 0 & Neg. & 0 & Neg. & E. coli & - & - & - & - & - & - & $\begin{array}{c}\text { Já } \\
\text { apresentou } \\
\text { episódios de } \\
\text { diarréia } \\
\text { anteriores à à } \\
\text { coleta }\end{array}$ \\
\hline 31 & $\begin{array}{l}\text { Gêmea } \\
\text { Clara }\end{array}$ & 60 & Diarréia & Neg. & Neg. & 0 & Neg. & 0 & Neg. & 0 & Neg. & E. coli & - & & & - & - & - & $\begin{array}{l}\text { Com diarréia } \\
/ 2 \text { colônias } \\
\text { de E. coli }\end{array}$ \\
\hline
\end{tabular}

Quadro 14 - Resumo dos resultados obtidos na primeira colheita de amostras na fazenda com casos recorrentes de diarréia (conclusão) 


\begin{tabular}{|c|c|c|c|c|c|c|c|c|c|c|c|c|c|c|c|c|c|c|}
\hline \multicolumn{2}{|c|}{ Animal } & \multirow{3}{*}{$\begin{array}{l}\text { Idade } \\
\text { (dias) }\end{array}$} & \multirow[b]{3}{*}{ Clínica } & \multirow[b]{3}{*}{ BCoV } & \multirow[b]{3}{*}{ RV } & \multicolumn{4}{|c|}{ Coproparasitológico } & \multirow{2}{*}{\multicolumn{2}{|c|}{$\begin{array}{c}\text { Coproparasiotológico } \\
\text { Final }\end{array}$}} & \multirow[b]{3}{*}{ Bacteriológico } & \multicolumn{6}{|c|}{ Multiplex } \\
\hline \multirow{2}{*}{$\begin{array}{l}\text { Núm. } \\
\text { Exp. }\end{array}$} & \multirow{2}{*}{$\begin{array}{l}\text { Nome } \\
\text { Eldorado }\end{array}$} & & & & & & acarose & & 120-éter & & & & & & & & & \\
\hline & & & & & & Qtd. & Parasita & Qtd. & Parasita & Qtd. & Parasita & & Stx1 & Stx2 & eae & K99 & F41 & Sta \\
\hline \multirow[b]{3}{*}{1} & \multirow[b]{3}{*}{ Brincado } & \multirow[b]{3}{*}{75} & \multirow[b]{3}{*}{ Normal } & \multirow[b]{3}{*}{ Neg. } & \multirow[b]{3}{*}{ Pos. } & raros & Eimeria $s p p$ & raros & Eimeria $s p p$ & raros & Eimeria $s p p$ & \multirow{3}{*}{$\begin{array}{c}\text { E. coli }+ \\
\text { Edwarsiella } \\
\text { hoshinae }+ \\
\text { Klebsiella } \\
\text { pneumoniae } \\
\text { subesp. } \\
\text { pneumoniae }\end{array}$} & \multirow[b]{3}{*}{-} & \multirow[b]{3}{*}{-} & \multirow[b]{3}{*}{-} & \multirow[b]{3}{*}{-} & \multirow[b]{3}{*}{-} & \multirow[b]{3}{*}{ - } \\
\hline & & & & & & raros & Strongyloidea & & & raros & Strongyloidea & & & & & & & \\
\hline & & & & & & raros & Trichuris & raros & Strongyloidea & raros & Trichuris & & & & & & & \\
\hline 2 & Brincado & 72 & Normal & Neg. & Neg. & raros & Eimeria $s p p$ & raros & Eimeria spp & raros & Eimeria spp & $\begin{array}{c}\text { E. coli + } \\
\text { Klebsiella } \\
\text { pneumoniae } \\
\text { subesp. } \\
\text { pneumoniae + } \\
\text { Edwarsiella } \\
\text { tarda biogrupo I }\end{array}$ & + & - & - & - & - & - \\
\hline 3 & Brincado & 95 & Normal & Neg. & Neg. & +++ & Eimeria spp & raros & Eimeria spp & +++ & Eimeria spp & $\begin{array}{c}\text { Klebsiella } \\
\text { pneumoniae } \\
\text { subesp. azanae + } \\
\text { Citrobacter } \\
\text { diversus }\end{array}$ & NA & NA & NA & NA & NA & NA \\
\hline 4 & Brincado & 125 & Normal & Neg. & Neg. & raros & Eimeria spp & raros & Eimeria spp & raros & Eimeria spp & $\begin{array}{c}\text { E. coli }+ \\
\text { Edwarsille tarda } \\
\text { biogrupo I }\end{array}$ & - & - & - & - & - & - \\
\hline \multirow[b]{2}{*}{5} & \multirow[b]{2}{*}{ Brincado } & \multirow[b]{2}{*}{70} & \multirow[b]{2}{*}{ Normal } & \multirow[b]{2}{*}{ Neg. } & \multirow[b]{2}{*}{ Neg. } & raros & Eimeria spp & & & raros & Eimeria spp & \multirow{2}{*}{$\begin{array}{c}\text { E. coli + } \\
\text { Klebsiella } \\
\text { pneumoniae } \\
\text { subesp. } \\
\text { pneumoniae } \\
\end{array}$} & \multirow[b]{2}{*}{+} & \multirow[b]{2}{*}{-} & & & & \\
\hline & & & & & & raros & Strongyloidea & raros & Eimeria $s p p$ & raros & Strongyloidea & & & & + & - & - & - \\
\hline & & & & & & & & raros & Eimeria spp & raros & Eimeria $s p p$ & $\begin{array}{c}\text { E. coli }+ \\
\text { Citrobacter }\end{array}$ & & & & & & \\
\hline 6 & Brincado & 95 & Normal & Neg. & Neg. & raros & Eimeria spp & raros & Trichuris & raros & Trichuris & $\begin{array}{c}\text { Klebsiella } \\
\text { pneumoniae } \\
\text { subesp. azanae }\end{array}$ & - & - & - & - & - & - \\
\hline 7 & Brincado & 110 & Normal & Neg. & Neg. & raros & Eimeria $s p p$ & raros & Eimeria spp & raros & Eimeria $s p p$ & $\begin{array}{c}\text { E. coli }+ \\
\text { Enterobacter spp }\end{array}$ & - & - & - & - & - & - \\
\hline
\end{tabular}

Quadro 15 - Resumo dos resultados obtidos na segunda colheita de amostras na fazenda com casos recorrentes de diarréia (continua) 


\begin{tabular}{|c|c|c|c|c|c|c|c|c|c|c|c|c|c|c|c|c|c|c|}
\hline \multicolumn{2}{|c|}{ Animal } & \multirow{3}{*}{$\begin{array}{l}\text { Idade } \\
\text { (dias) }\end{array}$} & \multirow{3}{*}{ Clínica } & \multirow[b]{3}{*}{ BCoV } & \multirow[b]{3}{*}{ RV } & \multicolumn{4}{|c|}{ Coproparasitológico } & \multirow{2}{*}{\multicolumn{2}{|c|}{$\begin{array}{c}\text { Coproparasiotológico } \\
\text { Final }\end{array}$}} & \multirow[b]{3}{*}{ Bacteriológico } & \multicolumn{6}{|c|}{ Multiplex } \\
\hline \multirow{2}{*}{$\begin{array}{l}\text { Núm. } \\
\text { Exp. }\end{array}$} & \multirow{2}{*}{\begin{tabular}{|c|} 
Nome \\
Eldorado
\end{tabular}} & & & & & & acarose & & 420-éter & & & & \multirow[b]{2}{*}{ Stx1 } & \multirow[b]{2}{*}{ Stx2 } & \multirow[b]{2}{*}{ eae } & \multirow[b]{2}{*}{ K99 } & \multirow[b]{2}{*}{ F41 } & \multirow[b]{2}{*}{ Sta } \\
\hline & & & & & & Qtd. & Parasita & Qtd. & Parasita & Qtd. & Parasita & & & & & & & \\
\hline \multirow[b]{2}{*}{8} & \multirow[b]{2}{*}{ Brincado } & \multirow[b]{2}{*}{125} & \multirow[b]{2}{*}{ Normal } & \multirow[b]{2}{*}{ Neg. } & \multirow[b]{2}{*}{ Pos. } & raros & Eimeria spp & raros & Eimeria $s p p$ & raros & Eimeria spp & \multirow{2}{*}{\begin{tabular}{|c} 
E. coli + Serratia \\
spp + Klebsiella \\
pneumoniae \\
subesp. \\
pneumoniae
\end{tabular}} & & & & & & \\
\hline & & & & & & raros & Strongyloidea & raros & Strongyloidea & raros & Strongyloidea & & - & + & - & - & - & - \\
\hline \multirow{3}{*}{9} & \multirow{3}{*}{ Brincado } & \multirow{3}{*}{95} & \multirow{3}{*}{ Normal } & \multirow{3}{*}{ Neg. } & \multirow{3}{*}{ Neg. } & raros & Eimeria spp & raros & Eimeria $s p p$ & raros & Eimeria $s p p$ & E. coli + & & & & & & \\
\hline & & & & & & raros & Strongyloidea & raros & Strongyloidea & raros & Strongyloidea & $\begin{array}{l}\text { Citrobacter } \\
\text { diversus + } \\
\text { Klehsiella }\end{array}$ & - & - & - & - & - & - \\
\hline & & & & & & raros & Trichuris & raros & Trichuris & raros & Trichuris & $\begin{array}{c}\text { pneumoniae } \\
\text { subesp. azanae }\end{array}$ & & & & & & \\
\hline & & & & & & raros & Eimeria $s p p$ & & & raros & Eimeria $s p p$ & Enterobacter $s p p$ & & & & & & \\
\hline 10 & Brincado & 125 & Normal & Neg. & Neg. & raros & Strongyloidea & raros & Eimeria spp & raros & Strongyloidea & $\begin{array}{c}\text { + Citrobacter } \\
\text { diversus }\end{array}$ & NA & NA & NA & NA & NA & NA \\
\hline 11 & Brincado & 110 & Normal & Neg. & Neg. & raros & Eimeria spp & raros & Eimeria spp & raros & Eimeria spp & $\begin{array}{c}\text { E. coli + } \\
\text { Edwarsiella } \\
\text { hoshinae }\end{array}$ & - & - & + & - & - & - \\
\hline 12 & Brincado & 95 & Normal & Neg. & Neg. & raros & Eimeria spp & raros & Eimeria spp & raros & Eimeria spp & $\begin{array}{c}\text { E. coli + } \\
\text { Citrobacter } \\
\text { amalonaticus + } \\
\text { Serratia spp + } \\
\text { Aeromonas } \\
\text { hydrophyla }\end{array}$ & + & - & - & - & - & \\
\hline 13 & Brincado & 95 & Normal & Neg. & Neg. & raros & Eimeria $s p p$ & raros & Eimeria $s p p$ & raros & Eimeria spp & $\begin{array}{c}\text { E. coli }+ \\
\text { Edwarsiella } \\
\text { tarda biogrupo I }\end{array}$ & - & - & - & - & - & - \\
\hline & & & & & & & & raros & Eimeria $s p p$ & raros & Eimeria spp & E. coli + & & & & & & \\
\hline 14 & Brincado & 125 & Normal & Neg. & Neg. & raros & Eimeria spp & raros & Strongyloidea & raros & Strongyloidea & $\begin{array}{c}\text { Citrobacter } \\
\text { amalonaticus + } \\
\text { Serratia spp }\end{array}$ & - & + & - & - & - & - \\
\hline & & & & & & ++ & Eimeria $s p p$ & & & ++ & Eimeria $s p p$ & E. coli + & & & & & & \\
\hline 15 & Brincado & 125 & Normal & Neg. & Neg. & raros & Trichuris & raros & Eimeria $s p p$ & raros & Trichuris & $\begin{array}{c}\text { Enterobacter spp } \\
+ \text { Edwarsiella } \\
\text { tarda biogrupo I }\end{array}$ & - & - & - & - & - & - \\
\hline & & & & & & & & raros & Eimeria $s p p$ & raros & Eimeria spp & E. coli + & & & & & & \\
\hline 16 & Brincado & 95 & Normal & Neg. & Neg. & 0 & Neg. & raros & Trichuris & raros & Trichuris & $\begin{array}{l}\text { Edwarsiella } \\
\text { hoshinae }\end{array}$ & + & - & - & - & - & - \\
\hline
\end{tabular}

Quadro 15 - Resumo dos resultados obtidos na segunda colheita de amostras na fazenda com casos recorrentes de diarréia (continua) 


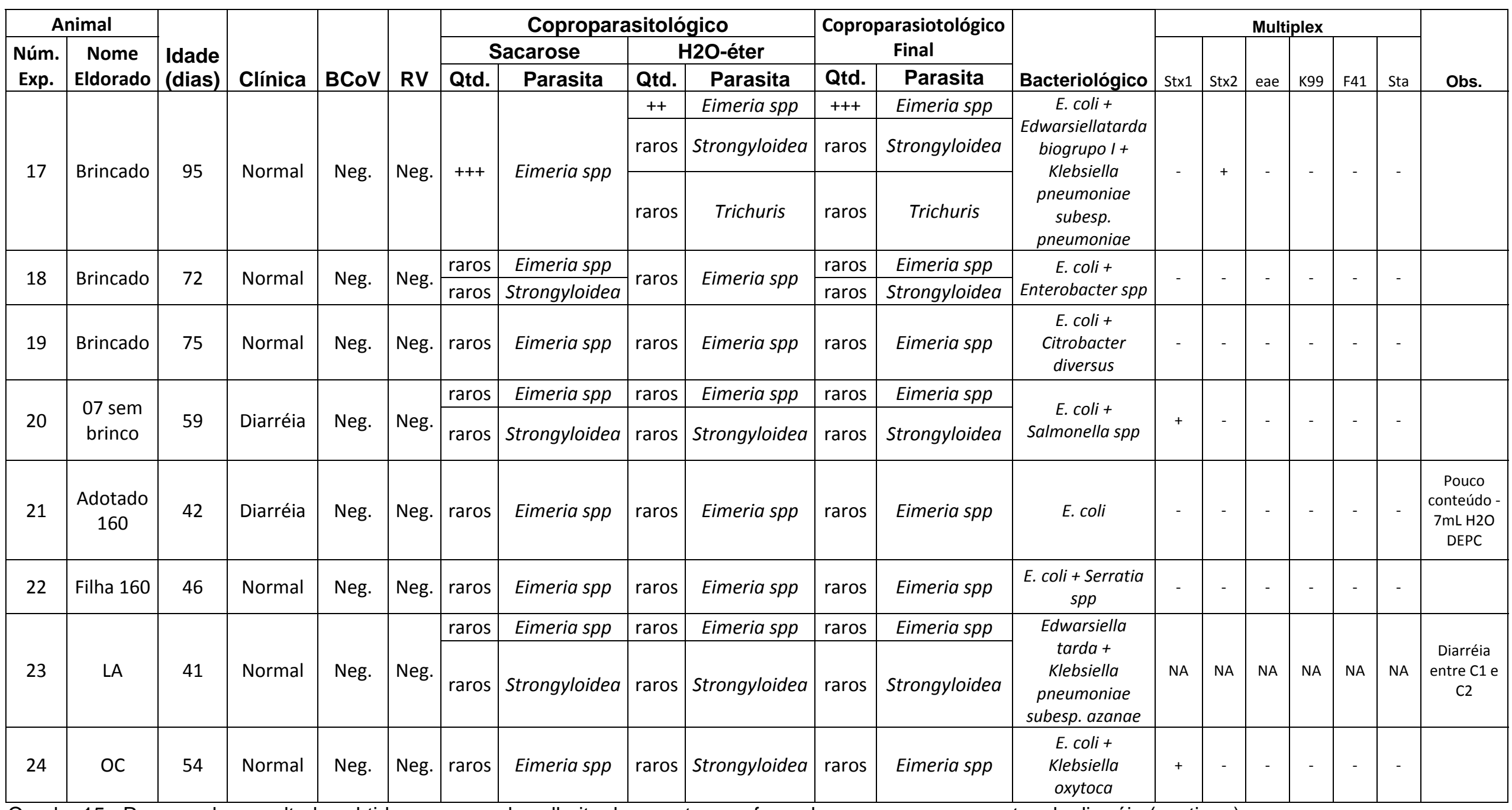

Quadro 15 - Resumo dos resultados obtidos na segunda colheita de amostras na fazenda com casos recorrentes de diarréia (continua) 


\begin{tabular}{|c|c|c|c|c|c|c|c|c|c|c|c|c|c|c|c|c|c|c|c|}
\hline \multicolumn{2}{|c|}{ Animal } & \multirow{3}{*}{$\begin{array}{l}\text { Idade } \\
\text { (dias) }\end{array}$} & \multirow[b]{3}{*}{ Clínica } & \multirow{3}{*}{$\begin{array}{c}\text { BCo } \\
\text { V }\end{array}$} & \multirow[b]{3}{*}{ RV } & \multicolumn{4}{|c|}{ Coproparasitológico } & \multirow{2}{*}{\multicolumn{2}{|c|}{$\begin{array}{c}\text { Coproparasiotológico } \\
\text { Final }\end{array}$}} & \multirow{3}{*}{$\begin{array}{c}\text { Bacteriológi } \\
\text { co }\end{array}$} & \multicolumn{6}{|c|}{ Multiplex } & \multirow[b]{3}{*}{ Obs. } \\
\hline Núm. & Nome & & & & & \multicolumn{2}{|c|}{ Sacarose } & \multicolumn{2}{|c|}{ H2O-éter } & & & & \multirow[b]{2}{*}{ Stx1 } & \multirow[b]{2}{*}{ Stx2 } & \multirow[b]{2}{*}{ eae } & \multirow[b]{2}{*}{ K99 } & \multirow[b]{2}{*}{ F41 } & \multirow[b]{2}{*}{ Sta } & \\
\hline Exp. & Eldorado & & & & & Qtd. & Parasita & Qtd. & Parasita & Qtd. & Parasita & & & & & & & & \\
\hline 25 & Garota & 69 & Normal & Neg. & Neg. & raros & Eimeria $s p p$ & raros & Eimeria $s p p$ & raros & Eimeria $s p p$ & $\begin{array}{c}\text { E. coli }+ \\
\text { Salmonella spp }\end{array}$ & - & + & - & - & - & - & \\
\hline \multirow[b]{2}{*}{26} & \multirow[b]{2}{*}{ Princesa } & \multirow[b]{2}{*}{59} & \multirow[b]{2}{*}{ Diarréia } & \multirow[b]{2}{*}{ Neg. } & \multirow[b]{2}{*}{ Neg. } & ++ & Eimeria spp & raros & Eimeria spp & ++ & Eimeria spp & \multirow{2}{*}{$\begin{array}{c}\text { Klebsiella } \\
\text { pneumoniae } \\
\text { subesp. azanae } \\
+ \text { Edwarsiella } \\
\text { hoshinae }\end{array}$} & \multirow[b]{2}{*}{ NA } & \multirow[b]{2}{*}{ NA } & \multirow[b]{2}{*}{ NA } & \multirow[b]{2}{*}{ NA } & \multirow[b]{2}{*}{ NA } & \multirow[b]{2}{*}{ NA } & \\
\hline & & & & & & raros & Strongyloidea & raros & Strongyloidea & raros & Strongyloidea & & & & & & & & \\
\hline \multirow[b]{2}{*}{27} & \multirow[b]{2}{*}{ Garça } & & & & & & & raros & Eimeria $s p p$ & raros & Eimeria spp & E. coli + & & & & & & & Diarréia \\
\hline & & 64 & Normal & Neg. & Neg. & raros & Eimeria spp & raros & Strongyloidea & raros & Strongyloidea & $\begin{array}{l}\text { Citrobacter } \\
\text { diversus }\end{array}$ & + & - & - & - & & & $\begin{array}{l}\text { entre } \\
\text { C1 e C2 }\end{array}$ \\
\hline 28 & Pintura & 54 & Normal & Neg. & Neg. & raros & Eimeria spp & 0 & Neg. & raros & Eimeria spp & E. coli & - & - & - & - & - & - & $\begin{array}{c}\text { Pouco } \\
\text { conteúd } \\
0-7 \mathrm{~mL} \\
\text { H2O } \\
\text { DEPC }\end{array}$ \\
\hline 29 & Mansinha & 44 & Normal & Neg. & Neg. & 0 & Neg. & 0 & Neg. & 0 & Neg. & Serratia spp & NA & NA & NA & NA & NA & NA & $\begin{array}{l}\text { Pouco } \\
\text { conteúd } \\
0-7 \mathrm{~mL} \\
\text { H2O } \\
\text { DEPC }\end{array}$ \\
\hline 30 & $\begin{array}{l}\text { Gêmea } \\
\text { Escura }\end{array}$ & 99 & Normal & Neg. & Neg. & raros & Eimeria spp & raros & Eimeria spp & raros & Eimeria spp & $\begin{array}{c}\text { E. coli + } \\
\text { Edwarsiella } \\
\text { hoshinae }\end{array}$ & - & - & + & & & & \\
\hline 31 & $\begin{array}{c}\text { Gêmea } \\
\text { Clara }\end{array}$ & 99 & Normal & Neg. & Neg. & raros & Eimeria spp & raros & Eimeria $s p p$ & raros & Eimeria spp & $\begin{array}{c}\text { E. coli }+ \\
\text { Enterobacter } \\
\text { spp }+ \\
\text { Edwarsiella } \\
\text { tarda biogrupo } \\
\text { I }\end{array}$ & - & + & - & - & - & - & \\
\hline
\end{tabular}

Quadro 15 - Resumo dos resultados obtidos na segunda colheita de amostras na fazenda com casos recorrentes de diarréia (continua) 


\begin{tabular}{|c|c|c|c|c|c|c|c|c|c|c|c|c|c|c|c|c|c|c|}
\hline \multicolumn{2}{|c|}{ Animal } & \multirow{3}{*}{$\begin{array}{l}\text { Idade } \\
\text { (dias) }\end{array}$} & \multirow{3}{*}{ Clínica } & \multirow{3}{*}{$\mathrm{BCoV}$} & \multirow{3}{*}{ RV } & \multicolumn{4}{|c|}{ Coproparasitológico } & \multirow{2}{*}{\multicolumn{2}{|c|}{$\begin{array}{c}\text { Coproparasiotológico } \\
\text { Final }\end{array}$}} & \multirow{3}{*}{ Bacteriológico } & \multicolumn{6}{|c|}{ Multiplex } \\
\hline \multirow{2}{*}{$\begin{array}{l}\text { Núm. } \\
\text { Exp. }\end{array}$} & \multirow{2}{*}{$\begin{array}{c}\text { Nome } \\
\text { Eldorado }\end{array}$} & & & & & & jacarose & & H2O-éter & & & & Sty 1 & Sty2 & & 1599 & FA1 & \\
\hline & & & & & & Qtd. & Parasita & Qtd. & Parasita & Qtd. & Parasita & & $S(x \perp$ & | $31 x<$ & eae & $1 \mathrm{ng}$ & $1 \mathrm{r}-4$ & Sta \\
\hline \multirow{2}{*}{1} & \multirow{2}{*}{ Brincado } & \multirow{2}{*}{98} & \multirow{2}{*}{ Normal } & \multirow{2}{*}{ Neg. } & \multirow{2}{*}{ Neg. } & raros & Eimeria spp & raros & Eimeria $s p p$ & raros & Eimeria $s p p$ & \multirow{2}{*}{$\begin{array}{l}\text { Citrobacter } \\
\text { diversus + } \\
\text { Serratia spp }\end{array}$} & \multirow{2}{*}{ NA } & \multirow{2}{*}{ NA } & \multirow{2}{*}{ NA } & \multirow{2}{*}{ NA } & \multirow{2}{*}{ NA } & \multirow{2}{*}{ NA } \\
\hline & & & & & & raros & Strongyloidea & raros & Strongyloidea & raros & Strongyloidea & & & & & & & \\
\hline 2 & Brincado & 95 & Normal & Neg. & Neg. & raros & Eimeria spp & raros & Eimeria spp & raros & Eimeria spp & $\begin{array}{c}\text { E. colit } \\
\text { Klebsiella } \\
\text { pneumoniae } \\
\text { subesp. azanae } \\
\text { + Citrobacter } \\
\text { amalonaticus }\end{array}$ & - & - & + & - & - & - \\
\hline 3 & Brincado & 118 & Normal & Neg. & Neg. & raros & Eimeria spp & raros & Eimeria spp & raros & Eimeria spp & E.coli & + & - & - & - & - & - \\
\hline \multirow{2}{*}{4} & \multirow{2}{*}{ Brincado } & \multirow{2}{*}{148} & \multirow{2}{*}{ Normal } & \multirow{2}{*}{ Neg. } & \multirow{2}{*}{ Neg. } & raros & Eimeria spp & raros & Eimeria spp & raros & Eimeria spp & \multirow{2}{*}{$\begin{array}{c}\text { E. coli + } \\
\text { Citrobacter } \\
\text { amalonaticus } \\
\end{array}$} & \multirow{2}{*}{+} & 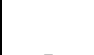 & + & 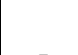 & 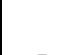 & 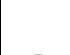 \\
\hline & & & & & & raros & Trichuris & raros & Trichuris & raros & Trichuris & & & - & + & - & - & - \\
\hline & & & & & & raros & Eimeria spp & raros & Eimeria spp & raros & Eimeria spp & $\begin{array}{c}\text { E. coli + } \\
\text { Enterobacter }\end{array}$ & & & & & & \\
\hline 5 & Brincado & 93 & Normal & Neg. & Neg. & raros & Strongyloidea & raros & Strongyloidea & raros & Strongyloidea & $\begin{array}{c}\text { spp + } \\
\text { Citrobacter } \\
\text { diversus }\end{array}$ & - & - & - & - & - & - \\
\hline 6 & Brincado & 118 & Normal & Neg. & Neg. & raros & Eimeria spp & raros & Eimeria spp & raros & Eimeria spp & $\begin{array}{c}\text { E. coli + } \\
\text { Edwarsiella } \\
\text { tarda biogrupo I }\end{array}$ & - & + & - & - & - & - \\
\hline 7 & Brincado & 133 & Normal & Neg. & Neg. & raros & Eimeria spp & raros & Eimeria spp & raros & Eimeria spp & $\begin{array}{c}\text { E. coli + } \\
\text { Klebsiella } \\
\text { pneumoniae } \\
\text { subesp. } \\
\text { pneumoniae } \\
\end{array}$ & - & - & - & - & - & - \\
\hline 8 & Brincado & 148 & Normal & Neg. & Neg. & raros & Eimeria spp & 0 & Neg. & raros & Eimeria spp & $\begin{array}{c}\text { E. coli + } \\
\text { Klebsiella } \\
\text { pneumoniae } \\
\text { subesp. azanae } \\
+ \text { Edwarsiella } \\
\text { tarda biogrupo I }\end{array}$ & - & - & - & - & - & - \\
\hline 9 & Brincado & 118 & Normal & Neg. & Neg. & raros & Eimeria spp & raros & Eimeria spp & raros & Eimeria spp & $\begin{array}{l}\text { Serratia spp + } \\
\text { Citrobacter } \\
\text { amalonaticus }\end{array}$ & NA & NA & NA & NA & NA & NA \\
\hline
\end{tabular}

Quadro 16 - Resumo dos resultados obtidos na terceira colheita de amostras na fazenda com casos recorrentes de diarréia (continua) 


\begin{tabular}{|c|c|c|c|c|c|c|c|c|c|c|c|c|c|c|c|c|c|c|}
\hline \multicolumn{2}{|c|}{ Animal } & \multirow{3}{*}{$\begin{array}{l}\text { Idade } \\
\text { (dias) }\end{array}$} & \multirow{3}{*}{ Clínica } & \multirow{3}{*}{$\mathrm{BCoV}$} & \multirow{3}{*}{$\mathbf{R V}$} & \multicolumn{4}{|c|}{ Coproparasitológico } & \multirow{2}{*}{\multicolumn{2}{|c|}{$\begin{array}{c}\text { Coproparasiotológico } \\
\text { Final }\end{array}$}} & \multirow{3}{*}{ Bacteriológico } & \multicolumn{6}{|c|}{ Multiplex } \\
\hline \multirow{2}{*}{$\begin{array}{l}\text { Núm. } \\
\text { Exp. }\end{array}$} & \multirow{2}{*}{$\begin{array}{c}\text { Nome } \\
\text { Eldorado }\end{array}$} & & & & & & arose & & T2O-éter & & & & Stro & Stro & ese & KOO & F44 & Sta \\
\hline & & & & & & Qtd. & Parasita & Qtd. & Parasita & Qtd. & Parasita & & $S 1 X \perp$ & Jixz & ede & n99 & 141 & Sid \\
\hline \multirow[b]{2}{*}{10} & \multirow[b]{2}{*}{ Brincado } & \multirow[b]{2}{*}{148} & \multirow[b]{2}{*}{ Normal } & \multirow[b]{2}{*}{ Neg. } & \multirow[b]{2}{*}{ Neg. } & \multirow[b]{2}{*}{ raros } & \multirow[b]{2}{*}{$\begin{array}{c}\text { Eimeria } \\
\text { spp }\end{array}$} & raros & Eimeria spp & raros & Eimeria spp & \multirow{2}{*}{$\begin{array}{l}\text { E. coli }+ \text { Klebsiella } \\
\text { pneumoniae } \\
\text { subesp. } \\
\text { pneumoniae }\end{array}$} & \multirow[b]{2}{*}{-} & \multirow[b]{2}{*}{-} & \multirow[b]{2}{*}{-} & \multirow[b]{2}{*}{ - } & \multirow[b]{2}{*}{-} & \multirow[b]{2}{*}{-} \\
\hline & & & & & & & & raros & Strongyloidea & raros & Strongyloidea & & & & & & & \\
\hline 11 & Brincado & 133 & Normal & Neg. & Neg. & raros & $\begin{array}{c}\text { Eimeria } \\
\text { spp }\end{array}$ & raros & Eimeria spp & raros & Eimeria spp & $\begin{array}{c}\text { E. coli + } \\
\text { Edwarsiella tarda } \\
\text { biogrupo I }\end{array}$ & - & + & - & - & - & - \\
\hline \multirow[b]{2}{*}{12} & \multirow[b]{2}{*}{ Brincado } & \multirow[b]{2}{*}{118} & \multirow[b]{2}{*}{ Normal } & \multirow[b]{2}{*}{ Neg. } & \multirow[b]{2}{*}{ Neg. } & \multirow[b]{2}{*}{ raros } & & raros & Eimeria spp & raros & Eimeria spp & E. coli + & & & & & & \\
\hline & & & & & & & spp & raros & Strongyloidea & raros & Strongyloidea & $\begin{array}{l}\text { Edwarsiella } \\
\text { hoshinae }\end{array}$ & - & - & - & - & - & - \\
\hline 13 & Brincado & 118 & Normal & Neg. & Neg. & raros & $\begin{array}{c}\text { Eimeria } \\
\text { spp }\end{array}$ & raros & Eimeria spp & raros & Eimeria spp & $\begin{array}{l}\text { E. coli + Klebsiella } \\
\text { pneumoniae } \\
\text { subesp. azanae + } \\
\text { Citrobacter } \\
\text { diversus }\end{array}$ & - & & - & - & - & - \\
\hline 14 & Brincado & 148 & Normal & Neg. & Neg. & raros & $\begin{array}{c}\text { Eimeria } \\
\text { spp }\end{array}$ & raros & Eimeria spp & raros & Eimeria spp & $\begin{array}{c}\text { E. coli + } \\
\text { Citrobacter } \\
\text { amalonaticus + } \\
\text { Serratia spp + } \\
\text { Aeromonas } \\
\text { hydrophila }\end{array}$ & + & - & - & - & - & - \\
\hline 15 & Brincado & 148 & Normal & Neg. & Neg. & raros & $\begin{array}{c}\text { Eimeria } \\
\text { spp }\end{array}$ & raros & Eimeria spp & raros & Eimeria spp & $\begin{array}{c}\text { E. coli }+ \\
\text { Edwarsiella } \\
\text { hoshinae }+ \\
\text { Klebsiella } \\
\text { pneumoniae } \\
\text { subesp. azanae } \\
\end{array}$ & - & + & - & - & - & - \\
\hline 16 & Brincado & 118 & Normal & Neg. & Neg. & raros & $\begin{array}{c}\text { Eimeria } \\
\text { spp }\end{array}$ & 0 & Neg. & raros & Eimeria spp & $\begin{array}{c}\text { E. coli + } \\
\text { Enterobacter spp } \\
+ \text { Citrobacter } \\
\text { diversus }\end{array}$ & - & & - & - & - & - \\
\hline 17 & Brincado & 118 & Normal & Neg. & Neg. & raros & $\begin{array}{c}\text { Eimeria } \\
\text { spp }\end{array}$ & raros & Eimeria spp & raros & Eimeria spp & $\begin{array}{c}\text { E. coli }+ \\
\text { Enterobacter spp }\end{array}$ & - & - & - & - & - & - \\
\hline
\end{tabular}

Quadro 16 - Resumo dos resultados obtidos na terceira colheita de amostras na fazenda com casos recorrentes de diarréia (continua) 


\begin{tabular}{|c|c|c|c|c|c|c|c|c|c|c|c|c|c|c|c|c|c|c|}
\hline \multicolumn{2}{|c|}{ Animal } & \multirow{3}{*}{$\begin{array}{l}\text { Idade } \\
\text { (dias) }\end{array}$} & \multirow{3}{*}{ Clínica } & \multirow{3}{*}{$\mathrm{BCoV}$} & \multirow{3}{*}{ RV } & \multicolumn{4}{|c|}{ Coproparasitológico } & \multirow{2}{*}{\multicolumn{2}{|c|}{$\begin{array}{c}\text { Coproparasiotológico } \\
\text { Final }\end{array}$}} & \multirow{3}{*}{ Bacteriológico } & \multicolumn{6}{|c|}{ Multiplex } \\
\hline \multirow{2}{*}{$\begin{array}{l}\text { Núm. } \\
\text { Exp. }\end{array}$} & \multirow{2}{*}{$\begin{array}{c}\text { Nome } \\
\text { Eldorado }\end{array}$} & & & & & & Sacarose & & H2O-éter & & & & 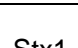 & ator 2 & & & & \\
\hline & & & & & & Qtd. & Parasita & Qtd. & Parasita & Qtd. & Parasita & & $S 1 \times 1$ & Six & eae & $k 99$ & $F 41$ & Sta \\
\hline 18 & Brincado & 95 & Normal & Neg. & Neg. & 0 & Neg. & 0 & Neg. & 0 & Neg. & $\begin{array}{l}\text { E. coli }+ \\
\text { Edwarsiella } \\
\text { hoshinae }\end{array}$ & - & - & - & - & - & - \\
\hline \multirow{3}{*}{19} & \multirow{3}{*}{ Brincado } & \multirow{3}{*}{98} & \multirow{3}{*}{ Normal } & \multirow{3}{*}{ Neg. } & \multirow{3}{*}{ Neg. } & raros & Eimeria spp & raros & Eimeria spp & raros & Eimeria spp & \multirow{3}{*}{$\begin{array}{c}\text { E. coli }+ \\
\text { Citrobacter } \\
\text { amalonaticus }\end{array}$} & \multirow{3}{*}{+} & \multirow{3}{*}{-} & \multirow{3}{*}{ - } & \multirow{3}{*}{-} & \multirow{3}{*}{ - } & \multirow{3}{*}{-} \\
\hline & & & & & & \multirow{2}{*}{ raros } & \multirow{2}{*}{ Strongyloidea } & raros & Strongyloidea & raros & Strongyloidea & & & & & & & \\
\hline & & & & & & & & raros & Strongyloides & raros & Strongyloides & & & & & & & \\
\hline 20 & $\begin{array}{l}07 \text { sem } \\
\text { brinco }\end{array}$ & 112 & Normal & Neg. & Neg. & raros & Eimeria spp & raros & Eimeria spp & raros & Eimeria spp & $\begin{array}{c}\text { E. coli+ } \\
\text { Edwarsiella } \\
\text { tarda biogrupo I } \\
+ \text { Klebsiella } \\
\text { pneumoniae } \\
\text { subesp. } \\
\text { pneumoniae }\end{array}$ & - & - & - & - & - & - \\
\hline 21 & $\begin{array}{c}\text { Adotado } \\
160\end{array}$ & 95 & Normal & Neg. & Neg. & raros & Eimeria spp & 0 & Neg. & raros & Eimeria spp & $\begin{array}{c}\text { E. coli + } \\
\text { Klebsiella } \\
\text { oxytoca }\end{array}$ & - & - & + & - & - & - \\
\hline \multirow{3}{*}{22} & \multirow{3}{*}{ Filha 160} & \multirow{3}{*}{95} & \multirow{3}{*}{ Normal } & & & raros & Eimeria spp & raros & Eimeria spp & raros & Eimeria spp & & & & & & & \\
\hline & & & & Neg. & Neg. & raros & Strongyloidea & raros & Strongyloidea & raros & Strongyloidea & Citrobacter & - & - & - & - & - & - \\
\hline & & & & & & Iarus & stromgyioraed & raros & Trichuris & raros & Trichuris & & & & & & & \\
\hline & & & & & & & & raros & Eimeria spp & raros & Eimeria spp & $\begin{array}{c}\text { E. coli + } \\
\text { Enterobacter }\end{array}$ & & & & & & \\
\hline 23 & LA & 99 & Normal & Neg. & Neg. & 0 & Neg. & raros & Strongyloidea & raros & Strongyloidea & $\begin{array}{c}\text { spp + Serratia } \\
\text { spp }\end{array}$ & - & + & & - & - & - \\
\hline & & & & & & & & raros & Eimeria spp & raros & Eimeria spp & E. coli + & & & & & & \\
\hline 24 & $\mathrm{OC}$ & 107 & Normal & Neg. & Neg. & raros & Eimeria $s p p$ & raros & Trichuris & raros & Trichuris & Edwarsiella & - & - & & - & - & - \\
\hline & & & & & & & & raros & Strongyloides & raros & Strongyloides & tarda biogrupo I & & & & & & \\
\hline & & & & & & raros & Eimeria spp & raros & Eimeria spp & raros & Eimeria spp & E. coli + & & & & & & \\
\hline 25 & Garota & 122 & Normal & Neg. & Neg. & raros & Strongyloidea & raros & Strongyloidea & raros & Strongyloidea & $\begin{array}{l}\text { Citrobacter } \\
\text { freudii }+ \\
\text { Serratia spp }\end{array}$ & + & - & & & - & - \\
\hline
\end{tabular}

Quadro 16 - Resumo dos resultados obtidos na terceira colheita de amostras na fazenda com casos recorrentes de diarréia (continua) 


\begin{tabular}{|c|c|c|c|c|c|c|c|c|c|c|c|c|c|c|c|c|c|c|}
\hline \multicolumn{2}{|c|}{ Animal } & \multirow{3}{*}{$\begin{array}{l}\text { Idade } \\
\text { (dias) }\end{array}$} & \multirow{3}{*}{ Clínica } & \multirow{3}{*}{ BCoV } & \multirow{3}{*}{ RV } & \multicolumn{4}{|c|}{ Coproparasitológico } & \multirow{2}{*}{\multicolumn{2}{|c|}{$\begin{array}{c}\text { Coproparasiotológico } \\
\text { Final }\end{array}$}} & \multirow{3}{*}{ Bacteriológico } & \multicolumn{6}{|c|}{ Multiplex } \\
\hline \multirow{2}{*}{$\begin{array}{l}\text { Núm. } \\
\text { Exp. }\end{array}$} & \multirow{2}{*}{$\begin{array}{c}\text { Nome } \\
\text { Eldorado }\end{array}$} & & & & & \multicolumn{2}{|c|}{ Sacarose } & \multicolumn{2}{|c|}{ H2O-éter } & & & & \multirow{2}{*}{ Stx1 } & \multirow{2}{*}{ Stx2 } & \multirow{2}{*}{ eae } & \multirow{2}{*}{ K99 } & \multirow{2}{*}{ F41 } & \multirow{2}{*}{ Sta } \\
\hline & & & & & & Qtd. & Parasita & Qtd. & Parasita & Qtd. & Parasita & & & & & & & \\
\hline 26 & Princesa & 112 & Normal & Neg. & Neg. & raros & Eimeria spp & raros & Eimeria spp & raros & Eimeria spp & $\begin{array}{c}\text { E. coli }+ \text { Enterobacter } \\
\text { spp }\end{array}$ & - & - & - & - & - & - \\
\hline \multirow{2}{*}{27} & \multirow{2}{*}{ Garça } & \multirow{2}{*}{117} & \multirow{2}{*}{ Normal } & \multirow{2}{*}{ Neg. } & \multirow{2}{*}{ Neg. } & raros & Eimeria spp & \multirow{2}{*}{ raros } & \multirow{2}{*}{ Eimeria spp } & raros & Eimeria spp & \multirow{2}{*}{$\begin{array}{c}\text { E. coli + Edwarsiella } \\
\text { tarda biogrupo I }\end{array}$} & \multirow{2}{*}{+} & \multirow{2}{*}{-} & \multirow{2}{*}{-} & \multirow{2}{*}{ - } & \multirow{2}{*}{-} & \multirow{2}{*}{-} \\
\hline & & & & & & raros & Strongyloidea & & & raros & Strongyloidea & & & & & & & \\
\hline 28 & Pintura & 107 & Diarréia & Neg. & Neg. & raros & Eimeria spp & raros & Eimeria spp & raros & Eimeria spp & $\begin{array}{c}\text { E. coli + Klebsiella } \\
\text { pneumoniae subesp. } \\
\text { azanae + Serratia spp }\end{array}$ & - & - & - & - & - & - \\
\hline 29 & Mancinha & 07 & Normal & $\mathrm{Neg}$ & Neg & raros & Eimeria spp & 0 & $\mathrm{Neg}$ & raros & Eimeria spp & E. coli + Edwarsiella & & & & & & \\
\hline 29 & IMansınna & 91 & Normal & Neg. & Neg. & raros & Strongyloidea & 0 & Neg. & raros & Strongyloidea & tarda biogrupo I & - & - & - & - & - & - \\
\hline 30 & $\begin{array}{l}\text { Gêmea } \\
\text { Escura }\end{array}$ & 152 & Normal & Neg. & Neg. & raros & Eimeria spp & raros & Eimeria spp & raros & Eimeria spp & $\begin{array}{c}\text { E. coli }+ \text { Edwarsiella } \\
\text { hoshinae }\end{array}$ & - & - & - & - & - & - \\
\hline & Gêmea & & & & & raros & Eimeria spp & & & raros & Eimeria spp & E. coli + Citrobacter & & & & & & \\
\hline 31 & Clara & 152 & Normal & Neg. & Neg. & raros & Strongyloidea & raros & Eimeria spp & raros & Strongyloidea & $\begin{array}{c}\text { diversus + Edwarsiella } \\
\text { tarda biogrupo I }\end{array}$ & - & - & & - & - & - \\
\hline
\end{tabular}

Quadro 16 - Resumo dos resultados obtidos na terceira colheita de amostras na fazenda com casos recorrentes de diarréia (conclusão) 


\begin{tabular}{|c|c|c|c|c|c|c|c|c|c|c|c|c|c|c|c|c|c|c|}
\hline \multicolumn{2}{|c|}{ Animal } & \multirow{3}{*}{$\begin{array}{l}\text { Idade } \\
\text { (dias) }\end{array}$} & \multirow{3}{*}{ Clínica } & \multirow{3}{*}{$\mathrm{BCoV}$} & \multirow{3}{*}{ RV } & \multicolumn{4}{|c|}{ Coproparasitológico } & \multirow{2}{*}{\multicolumn{2}{|c|}{$\begin{array}{c}\text { Coproparasiotológico } \\
\text { Final }\end{array}$}} & \multirow{3}{*}{ Bacteriológico } & \multicolumn{6}{|c|}{ Multiplex } \\
\hline \multirow{2}{*}{$\begin{array}{l}\text { Núm. } \\
\text { Exp. }\end{array}$} & \multirow{2}{*}{$\begin{array}{c}\text { Nome } \\
\text { Eldorado }\end{array}$} & & & & & \multicolumn{2}{|c|}{ Sacarose } & \multicolumn{2}{|r|}{ H2O-éter } & & & & \multirow{2}{*}{ Stx1 } & \multirow{2}{*}{$\mathrm{St} \times 2$} & \multirow{2}{*}{ eae } & \multirow{2}{*}{ K99 } & \multirow{2}{*}{ F41 } & \multirow{2}{*}{ Sta } \\
\hline & & & & & & Qtd. & Parasita & Qtd. & Parasita & Qtd. & Parasita & & & & & & & \\
\hline 1 & Brincado & 130 & Normal & Neg. & Neg. & raros & Eimeria spp & raros & Eimeria spp & raros & Eimeria spp & $\begin{array}{c}\text { E. coli + } \\
\text { Edwarsiella } \\
\text { hoshinae }\end{array}$ & - & - & - & - & - & - \\
\hline \multirow{2}{*}{2} & \multirow{2}{*}{ Brincado } & \multirow{2}{*}{127} & \multirow{2}{*}{ Normal } & \multirow{2}{*}{ Neg. } & \multirow{2}{*}{ Neg. } & raros & Eimeria spp & \multirow{2}{*}{0} & \multirow{2}{*}{ Neg. } & raros & Eimeria spp & \multirow{2}{*}{$\begin{array}{c}\text { E. coli }+ \\
\text { Enterobacter spp }\end{array}$} & \multirow{2}{*}{+} & & \multirow{2}{*}{+} & \multirow{2}{*}{ - } & & \\
\hline & & & & & & raros & Strongyloidea & & & raros & Strongyloidea & & & & & & & \\
\hline & & & & & & & & raros & Eimeria spp & raros & Eimeria spp & & & & & & & \\
\hline 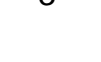 & Drimivano & 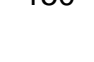 & - Nemina & treg. & Ney. & s tarus & 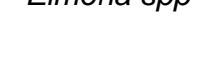 & raros & Trichuris & raros & Trichuris & ‥ $60 n$ & & 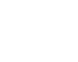 & & 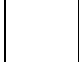 & . & \\
\hline 4 & Brincado & 180 & Normal & Neg. & Neg. & raros & Eimeria spp & raros & Eimeria spp & raros & Eimeria spp & $\begin{array}{c}\text { Enterobacter spp + } \\
\text { Citrobacter } \\
\text { diversus } \\
\end{array}$ & NA & NA & NA & NA & NA & NA \\
\hline & & & & & & raros & Eimeria spp & & & raros & Eimeria spp & & & & & & & \\
\hline 5 & Brincado & 125 & Normal & Neg. & Neg. & raros & Trichuris & raros & Eimeria spp & raros & Trichuris & Edwarsiella & - & - & - & - & - & - \\
\hline & & & & & & raros & Strongyloidea & & & raros & Strongyloidea & & & & & & & \\
\hline 6 & Brincado & 150 & Normal & Neg. & Neg. & raros & Eimeria spp & 0 & Neg. & raros & Eimeria spp & $\begin{array}{l}\text { Serratia spp + } \\
\text { Citrobacter } \\
\text { amalonaticus }\end{array}$ & NA & NA & NA & NA & NA & NA \\
\hline & & & & & & raros & Eimeria spp & raros & Eimeria spp & raros & Eimeria spp & & & & & & & \\
\hline 1 & Dinticaue & & Numinal & Treg. & Treg. & raros & Strongyloidea & raros & Strongyloidea & raros & Strongyloidea & ㄷ. CoII & & & & & & \\
\hline 8 & Brincado & 180 & Normal & Neg. & Neg. & raros & Eimeria spp & raros & Eimeria spp & raros & Eimeria spp & $\begin{array}{c}\text { Klebsiella } \\
\text { pneumoniae } \\
\text { subesp. azanae + } \\
\text { Citrobacter } \\
\text { diversus } \\
\end{array}$ & NA & NA & NA & NA & NA & NA \\
\hline
\end{tabular}

Quadro 17 - Resumo dos resultados obtidos na quarta colheita de amostras na fazenda com casos recorrentes de diarréia (continua) 


\begin{tabular}{|c|c|c|c|c|c|c|c|c|c|c|c|c|c|c|c|c|c|c|}
\hline \multicolumn{2}{|c|}{ Animal } & \multirow{3}{*}{$\begin{array}{l}\text { Idade } \\
\text { (dias) }\end{array}$} & \multirow{3}{*}{ Clínica } & \multirow{3}{*}{ BCoV } & \multirow{3}{*}{ RV } & \multicolumn{4}{|c|}{ Coproparasitológico } & \multirow{2}{*}{\multicolumn{2}{|c|}{$\begin{array}{c}\text { Coproparasiotológico } \\
\text { Final }\end{array}$}} & \multirow{3}{*}{ Bacteriológico } & \multicolumn{6}{|c|}{ Multiplex } \\
\hline \multirow{2}{*}{$\begin{array}{l}\text { Núm. } \\
\text { Exp. }\end{array}$} & \multirow{2}{*}{$\begin{array}{c}\text { Nome } \\
\text { Eldorado }\end{array}$} & & & & & & acarose & & H2O-éter & & & & Ctry & Ctyo & Po & KoO & $5 A 1$ & Sta \\
\hline & & & & & & Qtd. & Parasita & Qtd. & Parasita & Qtd. & Parasita & & SixI & $\operatorname{six} 2$ & eae & k99 & $1 \mathrm{~F}$ & Sla \\
\hline \multirow{3}{*}{9} & \multirow{3}{*}{ Brincado } & \multirow{3}{*}{150} & \multirow{3}{*}{ Normal } & \multirow{3}{*}{ Neg. } & \multirow{3}{*}{ Neg. } & +++++ & Eimeria spp & \multirow{3}{*}{+++} & \multirow{3}{*}{ Eimeria spp } & +++++ & Eimeria spp & \multirow{3}{*}{$\begin{array}{c}\text { E. coli }+ \\
\text { Edwarsiella } \\
\text { hoshinae }+ \\
\text { Klebsiella } \\
\text { pneumoniae } \\
\text { subesp. } \\
\text { pneumoniae }\end{array}$} & \multirow{3}{*}{-} & \multirow{3}{*}{-} & \multirow{3}{*}{-} & \multirow{3}{*}{-} & \multirow{3}{*}{-} & \multirow{3}{*}{-} \\
\hline & & & & & & raros & Trichuris & & & raros & Trichuris & & & & & & & \\
\hline & & & & & & raros & Strongyloidea & & & raros & Strongyloidea & & & & & & & \\
\hline 10 & Brincado & 180 & Normal & Neg. & Neg. & raros & Eimeria spp & raros & Eimeria spp & raros & Eimeria spp & $\begin{array}{c}\text { E. coli }+ \\
\text { Edwarsiella tarda } \\
\text { biogrupo I }\end{array}$ & - & + & - & - & - & - \\
\hline 11 & Brincado & 165 & Normal & Neg. & Neg. & ++ & Eimeria spp & raros & Eimeria spp & ++ & Eimeria spp & $\begin{array}{c}\text { Enterobacter spp } \\
+ \text { Klebsiella } \\
\text { pneumonia } \\
\text { subesp. azanae }\end{array}$ & NA & NA & NA & NA & NA & NA \\
\hline \multirow{2}{*}{12} & \multirow{2}{*}{ Brincado } & \multirow{2}{*}{150} & \multirow{2}{*}{ Normal } & \multirow{2}{*}{ Neg. } & \multirow{2}{*}{ Neg. } & raros & Eimeria spp & raros & Eimeria spp & raros & Eimeria spp & \multirow{2}{*}{$\begin{array}{c}\text { E. coli }+ \\
\text { Klebsiella } \\
\text { pneumoniae } \\
\text { subesp. azanae } \\
+ \text { Serratia spp } \\
\end{array}$} & & - & - & & & \\
\hline & & & & & & raros & Strongyloidea & raros & Strongyloidea & raros & Strongyloidea & & & & & & & \\
\hline 13 & Brincado & 150 & Normal & Neg. & Neg. & raros & Eimeria spp & raros & Eimeria spp & raros & Eimeria spp & $\begin{array}{c}\text { E. coli }+ \\
\text { Edwarsiella tarda }\end{array}$ & - & - & - & - & - & - \\
\hline 14 & Brincado & 180 & Normal & Neg. & Neg. & raros & Eimeria spp & raros & Eimeria spp & raros & Eimeria spp & $\begin{array}{c}\text { Citrobacter } \\
\text { amalonaticus + } \\
\text { Enterobacter spp } \\
\text { + Citrobacter } \\
\text { diversus }\end{array}$ & NA & NA & NA & NA & NA & NA \\
\hline
\end{tabular}

Quadro 17 - Resumo dos resultados obtidos na quarta colheita de amostras na fazenda com casos recorrentes de diarréia (continua) 


\begin{tabular}{|c|c|c|c|c|c|c|c|c|c|c|c|c|c|c|c|c|c|c|c|}
\hline \multicolumn{2}{|c|}{ Animal } & \multirow{3}{*}{$\begin{array}{l}\text { Idade } \\
\text { (dias) }\end{array}$} & \multirow{3}{*}{ Clínica } & \multirow{3}{*}{ BCoV } & \multirow{3}{*}{ RV } & \multicolumn{4}{|c|}{ Coproparasitológico } & \multirow{2}{*}{\multicolumn{2}{|c|}{$\begin{array}{c}\text { Coproparasiotol. } \\
\text { Final }\end{array}$}} & \multirow{3}{*}{ Bacteriológico } & \multicolumn{6}{|c|}{ Multiplex } & \multirow{3}{*}{ Obs. } \\
\hline Núm. & Nome & & & & & \multicolumn{2}{|c|}{ Sacarose } & \multicolumn{2}{|c|}{ H2O-éter } & & & & \multirow{2}{*}{ Stx1 } & \multirow{2}{*}{ Stx2 } & \multirow{2}{*}{ eae } & \multirow{2}{*}{ K99 } & \multirow{2}{*}{ F41 } & \multirow{2}{*}{ Sta } & \\
\hline Exp. & Eldorado & & & & & Qtd. & Parasita & Qtd. & Parasita & Qtd. & Parasita & & & & & & & & \\
\hline 15 & Brincado & 180 & Normal & Neg. & Neg. & raros & Eimeria spp & raros & Eimeria spp & raros & Eimeria spp & $\begin{array}{c}\text { E. coli + Klebsiella } \\
\text { pneumoniae subesp. } \\
\text { pneumoniae }+ \\
\text { Citrobacter diversus + } \\
\text { Klebsiella } \\
\text { pneumoniae subesp. } \\
\text { azanae }\end{array}$ & - & - & - & - & - & - & $\begin{array}{l}2 \text { colôn. } \\
\text { E. coli }\end{array}$ \\
\hline 16 & Brincado & 150 & Normal & Neg. & Neg. & raros & Eimeria spp & raros & Eimeria spp & raros & Eimeria spp & E. coli & - & - & - & - & - & - & $\begin{array}{l}2 \text { colôn. } \\
\text { E. coli }\end{array}$ \\
\hline 17 & Brincado & 150 & Normal & Neg. & Neg. & raros & Eimeria spp & raros & Eimeria spp & raros & Eimeria spp & $\begin{array}{c}\text { E. coli + Citrobacter } \\
\text { amalonaticus }+ \\
\text { Enterobacter spp }+ \\
\text { Klebsiella } \\
\text { pneumoniae subesp. } \\
\text { azanae }\end{array}$ & - & - & - & - & - & - & \\
\hline 18 & Brincado & 127 & Normal & Neg. & Neg. & raros & Eimeria spp & raros & Eimeria spp & raros & Eimeria spp & $\begin{array}{c}\text { E. coli }+ \text { Enterobacter } \\
\text { spp }\end{array}$ & - & - & - & - & - & - & \\
\hline \multirow{3}{*}{19} & \multirow{3}{*}{ Brincado } & \multirow{3}{*}{130} & \multirow{3}{*}{ Normal } & \multirow{3}{*}{ Neg. } & \multirow{3}{*}{ Neg. } & \multirow{3}{*}{ raros } & \multirow{3}{*}{ Eimeria spp } & raros & Eimeria spp & raros & Eimeria spp & \multirow{3}{*}{$\begin{array}{c}\text { E. coli + Citrobacter } \\
\text { amalonaticus + } \\
\text { Serratia spp + } \\
\text { Aeromonas } \\
\text { hydrophyla }\end{array}$} & \multirow{3}{*}{+} & \multirow{3}{*}{ - } & \multirow{3}{*}{-} & & & & \multirow{3}{*}{$\begin{array}{l}\text { Fezes } \\
\text { com } \\
\text { consis- } \\
\text { tência } \\
\text { reduzi- } \\
\text { da }\end{array}$} \\
\hline & & & & & & & & raros & Trichuris & raros & Trichuris & & & & & & & & \\
\hline & & & & & & & & raros & Strongyloidea & raros & Strongyloidea & & & & & & & & \\
\hline
\end{tabular}

Quadro 17 - Resumo dos resultados obtidos na quarta colheita de amostras na fazenda com casos recorrentes de diarréia (continua) 


\begin{tabular}{|c|c|c|c|c|c|c|c|c|c|c|c|c|c|c|c|c|c|c|}
\hline \multicolumn{2}{|c|}{ Animal } & \multirow{3}{*}{$\begin{array}{l}\text { Idade } \\
\text { (dias) }\end{array}$} & \multirow{3}{*}{ Clínica } & \multirow{3}{*}{ BCoV } & \multirow{3}{*}{ RV } & \multicolumn{4}{|c|}{ Coproparasitológico } & \multirow{2}{*}{\multicolumn{2}{|c|}{$\begin{array}{c}\text { Coproparasiotológico } \\
\text { Final }\end{array}$}} & \multirow{3}{*}{ Bacteriológico } & \multicolumn{6}{|c|}{ Multiplex } \\
\hline \multirow{2}{*}{$\begin{array}{l}\text { Núm. } \\
\text { Exp. }\end{array}$} & \multirow{2}{*}{$\begin{array}{c}\text { Nome } \\
\text { Eldorado }\end{array}$} & & & & & & Sacarose & & H2O-éter & & & & & & & & & \\
\hline & & & & & & Qtd. & Parasita & Qtd. & Parasita & Qtd. & Parasita & & Stx1 & Stx2 & eae & K99 & F41 & Sta \\
\hline \multirow{2}{*}{20} & \multirow{2}{*}{$\begin{array}{c}07 \text { sem } \\
\text { brinco }\end{array}$} & \multirow{2}{*}{139} & \multirow{2}{*}{ Normal } & \multirow{2}{*}{ Neg. } & \multirow{2}{*}{ Neg. } & raros & Eimeria spp & raros & Eimeria spp & raros & Eimeria spp & \multirow{2}{*}{$\begin{array}{c}\text { E. coli + } \\
\text { Citrobacter } \\
\text { amalonaticus + } \\
\text { Serratia spp }\end{array}$} & \multirow{2}{*}{ - } & \multirow{2}{*}{ - } & \multirow{2}{*}{ - } & \multirow{2}{*}{-} & \multirow{2}{*}{-} & \\
\hline & & & & & & raros & Strongyloides & raros & Strongyloides & raros & Strongyloides & & & & & & & \\
\hline \multirow[b]{2}{*}{21} & \multirow[b]{2}{*}{$\begin{array}{c}\text { Adotado } \\
160\end{array}$} & \multirow[b]{2}{*}{122} & \multirow[b]{2}{*}{ Diarréia } & \multirow[b]{2}{*}{ Neg. } & \multirow[b]{2}{*}{ Neg. } & \multirow[b]{2}{*}{0} & \multirow[b]{2}{*}{ Neg. } & raros & Strongyloides & raros & Strongyloides & \multirow{2}{*}{$\begin{array}{c}\text { E. coli + } \\
\text { Klebsiella } \\
\text { pneumoniae } \\
\text { subesp. azanae } \\
\text { + Citrobacter } \\
\text { amalonaticus + } \\
\text { Klebsiella } \\
\text { pneumoniae } \\
\text { subesp. } \\
\text { nneumoniae + } \\
\text { Klebsiella } \\
\text { pneumoniae } \\
\text { subesp. } \\
\text { rhinoscleromatis }\end{array}$} & \multirow[b]{2}{*}{ - } & & & & & \\
\hline & & & & & & & & raros & Trichuris & raros & Trichuris & & & - & - & & & \\
\hline 22 & Filha 160 & 122 & Diarréia & Neg. & Neg. & raros & Eimeria spp & 0 & Neg. & raros & Eimeria spp & $\begin{array}{c}\text { E. coli + } \\
\text { Klebsiella } \\
\text { pneumoniae } \\
\text { subesp. azanae } \\
\text { + Citrobacter } \\
\text { amalonaticus }\end{array}$ & - & - & - & - & - & - \\
\hline 23 & LA & 126 & Normal & Neg. & Neg. & raros & Eimeria spp & 0 & Neg. & raros & Eimeria spp & E. coli & - & - & - & - & - & - \\
\hline & & & & & & raros & Eimeria spp & raros & Eimeria spp & raros & Eimeria spp & & & & & & & \\
\hline & & (2) & - & (x) & [Nog. & raros & Strongyloidea & raros & Strongyloidea & raros & Strongyloidea & & & & & & & \\
\hline
\end{tabular}

Quadro 17 - Resumo dos resultados obtidos na quarta colheita de amostras na fazenda com casos recorrentes de diarréia (continua) 


\begin{tabular}{|c|c|c|c|c|c|c|c|c|c|c|c|c|c|c|c|c|c|c|c|}
\hline \multicolumn{2}{|c|}{ Animal } & \multirow{3}{*}{$\begin{array}{l}\text { Idade } \\
\text { (dias) }\end{array}$} & \multirow{3}{*}{ Clínica } & \multirow{3}{*}{ BCoV } & \multirow{3}{*}{ RV } & \multicolumn{4}{|c|}{ Coproparasitológico } & \multirow{2}{*}{\multicolumn{2}{|c|}{$\begin{array}{c}\text { Coproparasiotológi } \\
\text { co Final }\end{array}$}} & \multirow{3}{*}{ Bacteriológico } & \multicolumn{6}{|c|}{ Multiplex } & \multirow{3}{*}{ Obs. } \\
\hline Núm. & Nome & & & & & \multicolumn{2}{|c|}{ Sacarose } & \multicolumn{2}{|c|}{ H2O-éter } & & & & & & & & & & \\
\hline Exp. & Eldorado & & & & & Qtd. & Parasita & Qtd. & Parasita & Qtd. & Parasita & & Stx1 & Stx2 & eae & K99 & F-41 & Sta & \\
\hline 25 & Garota & 149 & Normal & Neg. & Neg. & raros & Eimeria spp & raros & Eimeria spp & raros & Eimeria spp & $\begin{array}{l}\text { E. coli }+ \text { Serratia spp } \\
+ \text { Klebsiella } \\
\text { pneumoniae subesp. } \\
\text { pneumoniae }\end{array}$ & - & - & - & - & - & - & \\
\hline \multirow{4}{*}{26} & \multirow{4}{*}{ Princesa } & \multirow{4}{*}{139} & \multirow{4}{*}{ Diarréia } & \multirow{4}{*}{ Neg. } & \multirow{4}{*}{ Neg. } & \multirow{4}{*}{ raros } & \multirow{4}{*}{ Eimeria spp } & raros & Eimeria spp & raros & Eimeria spp & \multirow{4}{*}{$\begin{array}{l}\text { E. coli + Yersinia spp } \\
+ \text { Klebsiella } \\
\text { pneumoniae subesp. } \\
\text { pneumoniae }+ \\
\text { Serratia spp }\end{array}$} & \multirow{4}{*}{ - } & \multirow{4}{*}{ - } & \multirow{4}{*}{ - } & \multirow{4}{*}{ - } & \multirow{4}{*}{-} & \multirow{4}{*}{-} & \multirow{4}{*}{$\begin{array}{l}\text { Pouco } \\
\text { conteú- } \\
\text { do } 4 \mathrm{~mL} \\
\text { H2O } \\
\text { DEPC / } \\
2 \text { E. coli }\end{array}$} \\
\hline & & & & & & & & raros & Strongyloidea & raros & Strongyloidea & & & & & & & & \\
\hline & & & & & & & & raros & Strongyloides & raros & Strongyloides & & & & & & & & \\
\hline & & & & & & & & raros & Trichuris & raros & Trichuris & & & & & & & & \\
\hline \multirow{2}{*}{27} & \multirow{2}{*}{ Garça } & \multirow{2}{*}{144} & \multirow{2}{*}{ Normal } & \multirow{2}{*}{ Neg. } & \multirow{2}{*}{ Neg. } & raros & Eimeria spp & & & raros & Eimeria spp & $\begin{array}{c}\text { E. coli + Yersinia spp } \\
+ \text { Klebsiella }\end{array}$ & & & & & & & \\
\hline & & & & & & raros & Strongyloidea & Ialus & Emmenta spp & raros & Strongyloidea & $\begin{array}{c}\text { azanae + Serratia } \\
\text { spp } \\
\end{array}$ & & - & - & & & & \\
\hline 28 & Pintura & 134 & Diarréia & Neg. & Neg. & raros & Eimeria spp & raros & Eimeria spp & raros & Eimeria spp & E. coli & - & + & - & - & - & - & $\begin{array}{c}\text { Conteúd } \\
\text { o reduli- } \\
\text { do } \\
\text { trazei-ro } \\
\text { sujo }\end{array}$ \\
\hline
\end{tabular}

Quadro 18 - Resumo dos resultados obtidos na quarta colheita de amostras na fazenda com casos recorrentes de diarréia (continua) 


\begin{tabular}{|c|c|c|c|c|c|c|c|c|c|c|c|c|c|c|c|c|c|c|c|}
\hline \multicolumn{2}{|c|}{ Animal } & \multirow{3}{*}{$\begin{array}{l}\text { Idade } \\
\text { (dias) }\end{array}$} & \multirow{3}{*}{ Clínica } & \multirow{3}{*}{ BCoV } & \multirow{3}{*}{ RV } & \multicolumn{4}{|c|}{ Coproparasitológico } & \multirow{2}{*}{\multicolumn{2}{|c|}{$\begin{array}{c}\text { Coproparasiotológico } \\
\text { Final }\end{array}$}} & \multirow{3}{*}{ Bacteriológico } & \multicolumn{6}{|c|}{ Multiplex } & \multirow{3}{*}{ Obs. } \\
\hline Núm. & Nome & & & & & \multicolumn{2}{|c|}{ Sacarose } & \multicolumn{2}{|c|}{ H2O-éter } & & & & Stx1 & Stx2 & eae & K99 & F41 & Sta & \\
\hline Exp. & Eldorado & & & & & Qtd. & Parasita & Qtd. & Parasita & Qtd. & Parasita & & 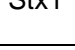 & $\iint^{2}$ & Eat & nas & $4+$ & Sia & \\
\hline 29 & Mansinha & 124 & Diarréia & Neg. & Neg. & raros & $\begin{array}{l}\text { Eimeria } \\
\text { spp }\end{array}$ & raros & $\begin{array}{l}\text { Eimeria } \\
\text { spp }\end{array}$ & raros & Eimeria spp & $\begin{array}{c}\text { E. coli + } \\
\text { Citrobacter } \\
\text { diversus + } \\
\text { Klebsiella } \\
\text { pneumoniae } \\
\text { subesp. } \\
\text { azanae }\end{array}$ & + & - & + & - & - & - & $\begin{array}{c}\text { Pouco } \\
\text { conteúdo } \\
4 \mathrm{~mL} \text { H2O } \\
\text { DEPC- } \\
\text { Diarréia } \\
\text { com } \\
\text { muco }\end{array}$ \\
\hline 30 & $\begin{array}{l}\text { Gêmea } \\
\text { Escura }\end{array}$ & 179 & Normal & Neg. & Neg. & raros & $\begin{array}{l}\text { Eimeria } \\
\qquad s p p\end{array}$ & raros & $\begin{array}{l}\text { Eimeria } \\
\text { spp }\end{array}$ & raros & Eimeria spp & $\begin{array}{c}\text { E. coli + } \\
\text { Klebsiella } \\
\text { pneumoniae } \\
\text { subesp. } \\
\text { pneumoniae + } \\
\text { Edwarsiella } \\
\text { tarda biogrupo } \\
\text { I }\end{array}$ & - & - & - & - & - & - & \\
\hline 31 & $\begin{array}{c}\text { Gêmea } \\
\text { Clara }\end{array}$ & 179 & Normal & Neg. & Neg. & raros & $\begin{array}{c}\text { Eimeria } \\
\text { spp }\end{array}$ & raros & $\begin{array}{c}\text { Eimeria } \\
\text { spp }\end{array}$ & raros & Eimeria spp & E. coli & - & - & - & - & - & - & \\
\hline
\end{tabular}

Quadro 17 - Resumo dos resultados obtidos na quarta colheita de amostras na fazenda com casos recorrentes de diarréia (conclusão) 